\title{
INTRODUÇÃO DE UMA MISTURA DE TRÊS ESPÉCIES FORRAGEIRAS DE INVERNO EM PASTAGEM IRRIGADA DE \\ CAPIM-ARUANA
}

\section{LUCIANA GERDES}

\begin{abstract}
Tese apresentada à Escola Superior de Agricultura “Luiz de Queiroz”, Universidade de São Paulo, para obtenção do título de Doutor em Agronomia, Área de Concentração: Ciência Animal e Pastagens.
\end{abstract}

P IR A C I C A B A

Estado de São Paulo - Brasil

Agosto- 2003 


\section{INTRODUÇÃO DE UMA MISTURA DE TRÊS ESPÉCIES FORRAGEIRAS DE INVERNO EM PASTAGEM IRRIGADA DE CAPIM-ARUANA}

\section{LUCIANA GERDES}

Engenheiro Agrônomo

Orientador: Prof. Dr. HERBERT BARBOSA DE MATTOS

Tese apresentada à Escola Superior de
Agricultura "Luiz de Queiroz", Universidade
de São Paulo, para obtenção do título de
Doutor em Agronomia, Área de
Concentração: Ciência Animal e Pastagens.

P I R A C I C A B A

Estado de São Paulo - Brasil

Agosto - 2003 
Dados Internacionais de Catalogação na Publicação (CIP) DIVISÃO DE BIBLIOTECA E DOCUMENTAÇÃO - ESALQ/USP

\section{Gerdes, Luciana}

Introdução de uma mistura de três espécies forrageiras de invemo em pastagem irigada de capim-anuana / Luciana Gerdes. - - Piracicaba, 2003.

$73 \mathrm{p}$.

Tese (doutorado) - Escola Superior de Agric ultura Luiz de Queiroz, 2003. Bibliografia.

1. Aveia preta 2. Azevém 3. Forragem 4. Imigação 5. Ovinos6. Produção vegetal 7. Trevo branco 8. Valor nutritivo I. Título

CDD 633.2 
A meus pais Saly e René,

Aos meus irmãos: Tânia, René, Karime e Fabinho,

Aos meus sobrinhos: Camila, Giulia, Bebel e Zé Arthur,

Ao amor da minha vida: Renato,

Aos meus cunhados: Lazslo, Tutu e Assja

pelo amor, apoio e incentivo

\section{OFEREÇO}

Tantas vezes pensamos ter chegado

Tantas vezes é preciso ir além

(Fernando Pessoa)

À minha mãe Saly "in memoriam"

pela sabedoria e exemplo de vida.

\section{DEDICO}




\section{AGRADECIMENTOS}

A DEUS, por iluminar meus caminhos e pela possibilidade infinita de crescimento, que se manifesta a cada instante em minha vida.

Ao Prof. Dr. Herbert Barbosa de Mattos, pelos ensinamentos, orientação e amizade desenvolvida.

Ao Coordenador Prof. Dr. Sila Carneiro da Silva e a todos os professores do Curso de Ciência Animal e Pastagens, pela dedicação e conhecimentos transmitidos.

Ao Dr. Joaquim Carlos Werner, pelo constante apoio na execução desse trabalho, pelos ensinamentos transmitidos, e principalmente pela amizade e carinho adquiridos desde o meu ingresso no curso de mestrado.

A equipe de pesquisadores da seção de ovinos do Instituto de Zootecnia: Luis Eduardo dos Santos, Eduardo Antônio da Cunha e Mauro Sartori Bueno, por toda infra estrutura e animais cedidos para a realização do experimento a campo, pela colaboração, troca de conhecimentos e amizade desenvolvida.

A Maria Tereza Colozza ,pela colaboração na execução desse trabalho, desde a coleta de dados a campo até a realização das análises bromatológicas e pela preciosa amizade.

Ao Flávio Rubens de Jesus e Antonio Marco Pigato, pela grande ajuda na coleta de dados e condução do experimento e pela nossa grande amizade.

Aos funcionário da seção de ovinos do Instituto de Zootecnia: Maria de Lourdes T. Santiago, Onofre Martins, Mauro Bertolai, Paulo Pereira dos Santos, José Sperchi e Joaquim de Nascimento, pela colaboração no manejo dos animais e pela nossa amizade.

Aos amigos Alessandra, Wald e Dora que colaboraram para a condução da Tese. 
A Rosana Aparecida Possenti e funcionários do Laboratório de Bromatologia e Minerais: Neuza A. Chaves, Carmem de Lourdes Terra, Maria Aparecida Menale, Sérgio Renato Miante, Zenairde R. da S. Palomo e Nivaldo Martins, pelo auxílio na realização das análises bromatológicas e pela amizade.

A Eliana Aparecida Schammass, pelo auxílio na realização das análises estatísticas e pela grande amizade.

As bibliotecárias do Instituto de Zootecnia: Lourdes Domingues dos Santos e Maria de Fátima A. Figueiredo pela contribuição durante a realização da Tese.

Aos funcionários do Instituto de Zootecnia: Verônica Farias de S. Ozolin, Liberaci Maria R. Q. da Silva, Valmir Antônio Barilon, Luzia Francisca de A. Pereira, Maria Aparecida de Barros e Silvia Helena Sanches, que colaboraram para realização da minha Tese.

Ao Instituto de Zootecnia, em Nova Odessa, mais uma vez, pela infra-estrutura cedida para realização da Tese.

A Fundação de Amparo à Pesquisa do Estado de São Paulo- FAPESP, pela concessão de bolsa para o curso de Doutorado.

Ao Prof. Dr. Francisco Monteiro, pelo incentivo na minha atuação de doutoranda, pela troca de conhecimentos e amizade desenvolvida.

Ao Prof. Dr. Carlos Guilherme Silveira Pedreira, pelas sugestões para a realização do trabalho e amizade desenvolvida.

Ao Prof. Dr. Ricardo de Andrade Reis, pela troca de conhecimentos e sugestões para a realização do trabalho.

Aos amigos que conviveram comigo nesta etapa da minha vida: Kátia, Maria Del Carmen, Micha, Daniele, Alessandra, Waldeliza, Rosane, Juliana, Lilian, Lúcia, Suzana, Soraia, Marta, Aline, Henrique Rocha, Sérgio, Alexandre Mello, Raul, Wald, Batata, Felipe, Leonardo, João Menezes, Gustavo, Daniel e Daniel Sarmento, pela valiosa amizade adquirida.

A todos os colegas do Curso de Ciência Animal e Pastagens, pela convivência alegre e constante trocas de experiências e conhecimentos. 
A Giovana, pela sua excelente atuação na secretaria da pós-graduação do referente curso e pela amizade desenvolvida.

A Creide, secretária do departamento de Zootecnia, pela colaboração durante o curso de Doutorado e amizade desenvolvida.

As bibliotecárias da ESALQ: Eliana Maria Garcia e Silvia Zinsly, pelas correções (formatação e referências bibliográficas) sugeridas para a Tese.

Em especial a minha família, pelo carinho, apoio, incentivo e compreensão fundamentais durante estes anos transcorridos.

A minha especial "ajudante do lar", Claudinha, que na minha ausência, colaborou com muito carinho tomando conta de Papai, Fabinho e Nina.

Ao meu grande amor Renato, pela nossa busca constante de nossos ideais e reciprocidade mútua de amor, paciência e perseverança rumo à carreira científica. 


\section{SUMÁRIO}

Página

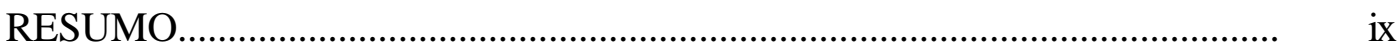

SUMMARY

1 INTRODUÇÃO

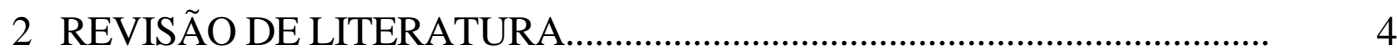

2.1 Estacionalidade de produção de forragens.......................................................

2.2 Panicum maximum Jacq. cv. Aruana............................................................. 6

2.3 Utilização de plantas forrageiras de inverno................................................... 7

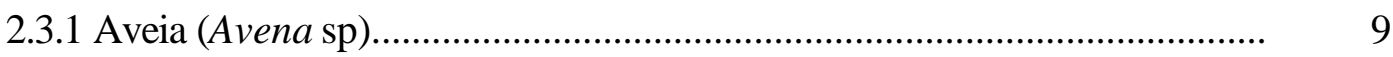

2.3.2 Azevém anual (Lolium multiflorum Lam.)............................................... 11

2.3.3 Trevo branco (Trifolium repens L.)........................................................... 12

2.4 Introdução de espécies forrageiras de inverno em pastagens estabelecidas.... 13

3 CARACTERÍSTICAS DO DOSSEL FORRAGEIRO E ACÚMULO DE FORRAGEM EM PASTAGEM IRRIGADA DE CAPIM-ARUANA EXCLUSIVO OU SOBRE-SEMEADO COM UMA MISTURA DE ESPÉCIES FORRAGEIRAS DE INVERNO.............................................. 16

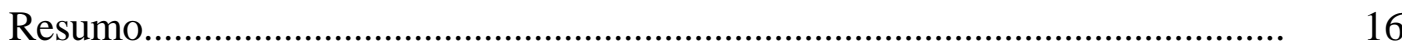

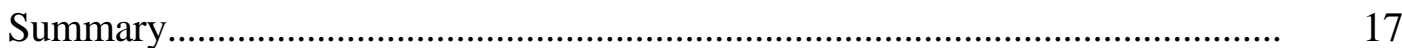

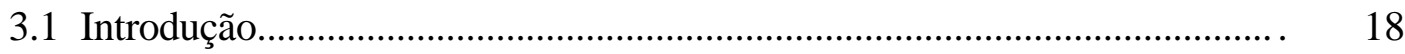

3.2 Material e Métodos....................................................................................... 20

3.3 Resultados e Discussão................................................................................ 26 
3.3.1 Primeiro Ano Experimental - Massa de forragem e dos componentes botânicos, acúmulo de forragem e taxa média diária de acúmulo de forragem, altura do dossel forrageiro e porcentagens de lâminas foliares.

3.3.2 Segundo Ano Experimental - Massa de forragem e dos componentes botânicos, acúmulo de forragem e taxa média diária de acúmulo de forragem, altura do dossel forrageiro e porcentagens de lâminas foliares.

3.4 Conclusões.

4 COMPOSIÇÃO QUÍMICA E DIGESTIBILIDADE DA MASSA DE FORRAGEM EM PASTAGEM IRRIGADA DE CAPIM-ARUANA EXCLUSIVO OU SOBRE-SEMEADO COM UMA MISTURA DE AVEIA PRETA E AZEVÉM.

Resumo

Summary

4.1 Introdução.

4.2 Material e Métodos.

4.3 Resultados e Discussão.

4.3.1 Primeiro Ano Experimental - Composição química e digestibilidade da massa de forragem e dos componentes forrageiros.

4.3.2 Segundo Ano Experimental - Composição química e digestibilidade da massa de forragem e dos componentes forrageiros.

4.4 Conclusões.

5 CONCLUSÕES 63

REFERÊNCIAS BIBLIOGRÁFICAS. 64 


\section{INTRODUÇÃO DE UMA MISTURA DE TRÊS ESPÉCIES FORRAGEIRAS DE INVERNO EM PASTAGEM IRRIGADA DE CAPIM-ARUANA}

Autora: LUCIANA GERDES

Orientador: Prof. Dr. HERBERT BARBOSA DE MATTOS

\section{RESUMO}

No Instituto de Zootecnia, Nova Odessa, SP, em uma pastagem de capim-aruana (Panicum maximum Jacq. cv. Aruana) utilizada com ovinos em sistema intensivo de produção (irrigação, adubação e lotação rotacionada), foram sobre-semeadas as espécies forrageiras de inverno: aveia preta (Avena strigosa Schreb cv. Comum), azevém anual (Lolium multiflorum Lam. cv. Comum) e trevo branco (Trifolium repens L. cv. Zapicán) com o objetivo de suprir o déficit e melhorar o valor nutritivo da forragem no período crítico do ano. A sobre-semeadura foi efetuada em 14/04/00 e 07/06/01 no primeiro e segundo anos do experimento, respectivamente. Nos dois anos (14/04/00 a 18/01/01 e 07/06/01 a 22/02/02) foram avaliados, em seis períodos de pastejo: massa total de forragem pré-pastejo, sua composição botânica e porcentagem de lâminas foliares, massa de forragem pós-pastejo, acúmulo de forragem (AF) e taxa média diária de acúmulo de forragem (TMDAF) em cada período de rebrotação, altura do dossel forrageiro pré e pós-pastejo, características químicas: proteína bruta (PB), fibra em detergente neutro (FDN), fibra em detergente ácido (FDA), lignina e digestibilidade "in vitro" da matéria seca (DIVMS), nas amostras da massa total de forragem e nas dos 
componentes botânicos (aruana, aveia preta e azevém) pré-pastejo. O delineamento experimental foi o de blocos completos casualizados (quatro), com duas repetições dentro do bloco e dois tratamentos: 1) capim-aruana exclusivo (AE) e 2) sobresemeadura da mistura das três espécies forrageiras de inverno (MFI). Os blocos eram pastejados pelo mesmo lote de animais, em sequência, por dois a três dias, até atingir 10 a $15 \mathrm{~cm}$. O trevo-branco não se estabeleceu em ambos os anos. No primeiro ano, a pastagem MFI apresentou maior massa total de forragem do que a pastagem $\mathrm{AE}$ no segundo período e na média dos seis períodos. A aveia apresentou a maior contribuição no segundo período e o azevém no terceiro. As pastagens com a MFI apresentaram maiores $\mathrm{AF}$ e TMDAF que as pastagens de AE no segundo, quinto e na média dos seis períodos. A PB da forragem na pastagem de capim-aruana exclusivo foi maior em relação à sobre-semeada no terceiro período de pastejo e semelhante nos demais. A PB dos componentes aveia e azevém, no terceiro período, foi menor em relação aos do primeiro e segundo. FDN, FDA e lignina da forragem no tratamento exclusivo foram mais elevados em relação aos do tratamento sobre-semeado, na média dos seis períodos. Aveia e azevém apresentaram FDN mais baixos nos períodos iniciais de crescimento, com aumento no último. A digestibilidade da forragem foi semelhante nos dois tratamentos, em todos os períodos de avaliação. No segundo ano, a massa total de forragem apresentou quantidades semelhantes entre as duas pastagens ao longo dos seis períodos e na sua média. A aveia esteve mais presente no primeiro período e o azevém no terceiro. Não houve diferença entre tipos de pastagem para AF e TMDAF em nenhum dos seis períodos, nem na sua média. Para o componente aruana a porcentagem de lâminas foi semelhante entre os dois tipos de pastagem e para a aveia e azevém, as menores porcentagens ocorreram no período final dos seus ciclos vegetativos, em ambos os anos. O teor de $\mathrm{PB}$ da massa total de forragem da pastagem de capim-aruana exclusivo foi maior que o da pastagem sobre-semeada, no quarto período mas semelhante nos demais e na média dos períodos. Os teores de PB da aveia e do azevém decresceram ao longo dos períodos de pastejo. Os teores de FDN, FDA, lignina e DIVMS da forragem foram semelhantes entre as duas pastagens na média e ao longo dos seis períodos, exceto para FDN no segundo período. A aveia e o azevém apresentaram 
os maiores teores de FDN, FDA e lignina no último período de pastejo. A DIVMS do azevém manteve-se constante nos dois primeiros períodos de pastejo diminuindo no último. Pastos de capim-aruana convenientemente adubados e irigados, que recebam sobre-semeadura com espécies forrageiras de inverno, produzem mais forragem no período crítico mas com valor nutritivo semelhante em relação a pastos não sobresemeados, nas condições do Estado de São Paulo. Pastos deste capim, não sobresemeados, mas que recebam adubação e irrigação também apresentam boa produção e valor nutritivo nesta época. 


\title{
INTRODUCTION OF A MIXTURE OF THREE WINTER FORAGE SPECIES IN AN IRRIGATED ARUANAGRASS PASTURE
}

\author{
Author: LUCIANA GERDES
}

Adviser: Prof. Dr. HERBERT BARBOSA DE MATTOS

\section{SUMMARY}

At Instituto de Zootecnia, Nova Odessa, SP, in a pasture of aruanagrass (Panicum maximum Jacq. cv. Aruana), grazed by sheep in an intensive production system (irrigation, fertilization and rotational stocking), it was introduced a three winter forage species: black oat (Avena strigosa Schreb. cv. Common), italian ryegrass (Lolium multiflorum Lam. cv. Common) and white clover (Trifolium repens L. cv. Zapican) with the objective of increasing the forage supply and its nutritive value during the dry winter period. The mixture was broadcasted sown over the grass on 04-14-00 and 06-07-01 in two years of experiment. From 04-14-00 to 01-18-01 and 06-07-01 to 02-22-02 it was evaluated, in six annual grazing periods, the forage mass, its botanical composition and leaf blades percentage pre grazing, residual mass post grazing, forage accumulation (FA) and mean forage accumulation daily rate (MFADR) in each regrowth period and sward heigth pre and post grazing, the chemical characteristics: crude protein (CP), neutral detergent fiber (NDF), acid detergent fiber (ADF), lignin and in vitro dry matter digestibility (IVDMD) in the forage on offer and in its botanical components. The experimental design was a completely randomized block (four) with two replications within the block. The treatments were: 1) grass alone and 2) the grass oversown with the 
mixture of the winter forages. The blocks were grazed by the same group of sheep in sequence for two or three days until the sward height reached to $10-15 \mathrm{~cm}$. The white clover did not establish. In the first year the oversown treatment presented higher total forage mass than the control in the second periods and in the mean of the six periods. The black oat presented higher contribution in the second period and italian ryegrass in the third. The oversown pastures presented higher FA and MFADR than the single aruanagrass pastures, in the second, fifth and in the mean of the six periods. The $\mathrm{CP}$ in the forage from the grass pasture alone was greater than the one of the oversown pasture in the third period, and similar in the others. Oat and ryegrass CP was lower in the third period than the ones of the first and second ones. NDF, ADF and lignin in the forage from the grass pasture alone were greater than the ones of the oversown pasture. Oat and ryegrass NDF was lowest in the initial growth periods, increasing in the final. Forage IVDMD from the two treatments were similar in all evaluation periods. In the second year, the total forage mass was similar in the two pasture treatments in all grazing periods and in their means. The black oat contribution was higher in the first period and the one of italian ryegrass in the third. The FA and the MFADR were similar in the two pasture systems. The leaf blades percentage of aruanagrass was similar in the two pastures in all periods and the ones of black oat and italian ryegrass were lower in the final period compared to the preceeding ones, in the two years. The $\mathrm{CP}$ in the forage from the grass pasture alone was greater than the one of the oversown pasture in the fourth period, and similar in the others. Oat and ryegrass $\mathrm{CP}$ decreased along the grazing periods. NDF, $\mathrm{ADF}$, lignin and IVDMD of the forage from the two treatments were similar in all evaluation periods. Oat and ryegrass NDF, ADF and lignin were greater in the last grazing period. Ryegrass IVDMD from the first two periods were similar and decreased in the final. For the São Paulo State conditions, adequately fertilized and irrigated aruanagrass pastures, when oversown with winter annual forages, yield more than single aruanagrass ones during the dry winter period but with similar nutritive value. Single aruanagrass pastures when fertilized and irrigated present also good forage yields with good nutritive value during this time. 


\section{INTRODUÇÃO}

O problema da estacionalidade de produção das plantas forrageiras em pastagens é enfatizado, tanto no Brasil, como na maioria das regiões do mundo, devido, principalmente, à não ocorrência de chuvas durante parte do ano. Essa característica vem limitando o crescimento de plantas forrageiras, alternando crescimento vigoroso e altas produções nos períodos quentes e úmidos, com baixas taxas de crescimento e baixas produções nas épocas secas e frias do ano, determinando um período restrito para produção de alimentos.

O Brasil apresenta condições favoráveis à exploração de sistemas de produção animal que utilizam pastagens. Entretanto, as diferenças edafoclimáticas das regiões brasileiras implicam na utilização destas forrageiras com mecanismos adaptativos bastante distintos, visando superar as pressões dos estresses ambientais e manter elevada produção e qualidade de forragem.

No Brasil Central e no Estado de São Paulo, o período crítico está relacionado a um acentuado déficit hídrico, especialmente no período compreendido entre junho e outubro, caracterizado por baixa capacidade de suporte devido à baixa disponibilidade de forragem nas pastagens. Esse fato gera redução da capacidade dos pecuaristas realizarem investimentos na modernização da atividade por não utilizarem nível tecnológico adequado para a obtenção de uma exploração pecuária eficiente. Esses fatores tem sido apontados como os que mais contribuem para a baixa produtividade animal, diminuindo drasticamente a produção de leite e ocasionando perda de peso pelos animais de corte.

Considerando as pressões do mercado, os produtores tem procurado obter aumento de produtividade com a intensificação do sistema produtivo, fato este que já vem ocorrendo em todo País, especialmente nas Regiões Sul, Sudeste e Centro-Oeste. 
As dificuldades apresentadas pelo ambiente de clima tropical para obtenção de uma produção de forragem mais uniforme durante o ano podem ser superadas através da utilização de diversas tecnologias. Entre elas destaca-se a introdução de plantas forrageiras de inverno em pastagens formadas com gramíneas tropicais, em épocas estratégicas como no final do período de crescimento do pasto. Esse procedimento provoca aumento substancial, tanto na quantidade, como na qualidade da forragem podendo alterar a distribuição da produção durante o ano, com a redução da necessidade de alimentação suplementar, neste período (Moraes \& Lustosa, 1999; Reis, et al., 1993; Reis et al., 2001).

O comportamento de uma planta forrageira de clima temperado em pastagens com espécies de clima tropical resulta da interação do seu potencial genético com o meio ambiente. Assim, para maximizar o potencial de produção forrageira e animal, pode-se adaptar a planta ao meio ambiente, utilizando eficientemente fatores como adubação, irrigação e manejo adequado da desfolhação.

As gramíneas tropicais, no Brasil Central, respondem por quase $100 \%$ da alimentação dos bovinos, seja em sistemas extensivos ou intensivos de exploração de pastagens. A sobre-semeadura de misturas de espécies forrageiras de ciclo hibernal nas pastagens de gramíneas tropicais visa combinar os picos de produção de massa seca que são atingidos em diferentes épocas do ano para cada espécie, resultando um aumento da produção e do período de utilização da pastagem (Fribourg \& Overton,1973; Lupatini et al., 1998a; Postiglioni, 1982; Roso et al., 1999).

O desempenho animal em pastagens de clima tropical é reconhecidamente inferior quando comparado àquele alcançado em pastagens de clima temperado. Esse fato tem sido atribuído às diferenças genéticas existentes entre as plantas forrageiras temperadas (plantas de ciclo $\mathrm{C}_{3}$ ) e as tropicais (plantas de ciclo $\mathrm{C}_{4}$ ). As gramíneas temperadas apresentam melhor qualidade em relação às tropicais, em termos de teor de proteína, fibras, digestibilidade e consumo. Isto ocorre porque as gramíneas temperadas apresentam parede celular mais fina, ou seja, contêm menores teores de compostos indigestíveis, como a lignina. Por outro lado, as de espécies tropicais apresentam maior eficiência fotossintética, sendo mais produtivas em termos de massa seca. 
A composição química da planta forrageira é um dos parâmetros utilizados para medir seu valor nutritivo nas pastagens. $\mathrm{O}$ valor nutritivo de uma planta forrageira é influenciado pelo gênero, espécie, cultivar, condições climáticas, estádio fisiológico, fertilidade do solo e pelo manejo da desfolhação a que é submetida (Euclides et al., 1996). Segundo esses autores, entre as gramíneas tropicais, os cultivares de P. maximum normalmente apresentam qualidade de média a boa.

Este trabalho teve como objetivo avaliar o desenvolvimento vegetativo e o valor nutritivo de uma pastagem de Panicum maximum Jacq. cv. Aruana, irrigada, adubada e manejada em lotação rotacionada com ovinos, na qual se introduziram simultaneamente, durante a estação de outono, três espécies forrageiras de inverno, visando a redução do déficit de produção e melhoria do valor nutritivo da forragem ofertada para os animais no período crítico do ano (fim do outono/inverno/início de primavera), nas condições do Estado de São Paulo. 


\section{REVISÃO DE LITERATURA}

\subsection{Estacionalidade de produção de forragens}

Dentre os aspectos desejáveis à utilização de plantas forrageiras, a distribuição uniforme da produção de forragem durante o ano pode ser considerada como um dos atributos mais atraentes e cobiçados pelos produtores. A estacionalidade da produção forrageira determina flutuação na alimentação dos bovinos baseada na produção das pastagens. Consequentemente, a produção pecuária apresenta ciclos de safra e entressafra (Gomide, 1990). No Brasil Central, cerca de 75 a $85 \%$ da produção total concentra-se no período quente e chuvoso, de outubro a março, e o restante (25 a $15 \%$ da produção total) no período frio e seco, de abril a setembro (Werner, 1970; Ghelfi Filho, 1972; Pedreira, 1973).

A distribuição estacional de água parece ser um dos mais importantes fatores climáticos, limitando a produção de forragens nos trópicos e subtrópicos (Cooper, 1970). A produção deficiente de forragem no inverno é causada pela limitação de água das chuvas e temperaturas baixas, especialmente no período compreendido entre junho e outubro. As plantas apresentam uma faixa de temperatura ótima para o seu crescimento, a qual está diretamente ligada ao ciclo fotossintético. Assim sendo, as plantas de ciclo $\mathrm{C}_{3}$ apresentam temperatura ótima de crescimento na faixa de 15 a $22^{\circ} \mathrm{C}$ e as de ciclo $\mathrm{C}_{4}$ na faixa de 22 a $35^{\circ} \mathrm{C}$ (Rodrigues \& Rodrigues, 1987).

O aparecimento de folhas, a senescência e a longevidade de folhas, além do desenvolvimento de gemas, respondem imediatamente a qualquer mudança de temperatura. Isso, por sua vez, influenciará as características estruturais do dossel 
forrageiro como o tamanho da folha, densidade populacional de perfilhos e número de folhas vivas por perfilho (Gomide, 1997; Lemaire \& Chapman, 1996).

As plantas forrageiras de origem tropical e subtropical apresentam crescimento reduzido durante o período de inverno. Dessa forma, de abril a setembro, quando as temperaturas e precipitação são baixas, ocorre diminuição na oferta de forragem nas pastagens.

O Panicum maximum Jacq., de forma semelhante a outras espécies forrageiras tropicais, também apresenta estacionalidade de produção durante o ano. Jank et al. (1994), trabalhando com 156 acessos de Panicum maximum Jacq. provenientes da África, encontraram aqueles que produziram, no "inverno", até $24 \%$ da produção anual, sendo que os acessos mais produtivos registraram maior estacionalidade de produção (amplitude de 5 a $13 \%$ no período das secas). Essa limitada produção de forragem durante o "inverno" tem sido apontada como um dos fatores que mais contribui para a baixa produtividade dos rebanhos, sendo responsável pela queda acentuada no desempenho animal e mesmo pela grande redução na capacidade de suporte dos pastos, vindo a dificultar a eficiência da atividade pecuária (Rolim, 1994).

A característica da estacionalidade de produção das gramíneas do gênero Panicum está ligada ao fato de serem, em sua grande maioria, plantas tropicais de fisiologia $\mathrm{C}_{4}$, caracterizadas por drástica redução em suas taxas fotossintéticas com temperaturas mínimas inferiores a $15^{\circ} \mathrm{C}$ (Cooper \& Tainton, 1968), sendo este um dos principais fatores responsáveis pela sua estacionalidade de produção.

O Panicum maximum Jacq. cv. Aruana tem se destacado por apresentar uma melhor distribuição anual de produção: 27 \% (Cecato et al., 1994), 37 \% (Ghisi et al., 1989) da produção total anual, associado a um razoável valor nutritivo (Ghisi et al., 1989) durante o período crítico no ano.

Um dos desafios da pecuária no Brasil é o não aproveitamento do potencial de produção animal que o país apresenta, uma vez que a lotação das pastagens é ajustada em função da produção mínima do "inverno" (Rolim, 1994). Acredita-se que à medida que a atividade pecuária vá alcançando maiores índices de especialização, deverá aumentar a demanda por tecnologias que controlem o processo de produção do pasto e 
sua oferta ao animal, na quantidade e qualidade necessárias para atingir determinado objetivo de produção.

\subsection{Panicum maximum Jacq. cv. Aruana}

O Panicum maximum Jacq. cv. Aruana foi lançado pelo Instituto de Zootecnia em 1989, sob o n̊ IZ-5, como uma opção para formação de pastagens. É proveniente da África, tendo vindo para Nova Odessa através de sementes trazidas do km 47 (Universidade Federal Rural do Rio de Janeiro) onde foi introduzido pelo doutor Jorge Ramos Otero (Instituto de Zootecnia, 1989).

É uma gramínea cespitosa de porte médio $(70 \mathrm{~cm}$ a $90 \mathrm{~cm}$ de altura), com grande quantidade de colmos finos. Tem folhas estreitas, de cor verde escuro e as panículas e espiguetas das inflorescências são pequenas. Esse cultivar apresenta boa tolerância ao pastejo baixo, com intensa capacidade de rebrotação através de gemas basais, com número de perfilhos superior ao colonião comum, principalmente no período de inverno, e um menor índice de área foliar e maior relação haste/folha. No entanto, devido aos colmos serem finos e tenros, são bem consumidos pelos animais (Cunha et al., 1999). Colozza (1998) encontrou maior número de perfilhos no capim-aruana quando comparado com o Panicum maximum Jacq. cv. Mombaça.

Cecato et al. (1996) avaliaram oito cultivares de Panicum maximum quanto à produção de matéria seca sob dois regimes de corte, entre eles o aruana, constatando alta variação na produtividade e na resposta aos fatores ambientais, como, temperatura, luz, nutrição mineral e suprimento de água, mesmo sendo os genótipos da mesma espécie.

Ghisi et al. (1989), estudando seis cultivares de Panicum maximum Jacq., constataram que os cultivares aruana e IPEACS apresentaram melhor distribuição anual de produção de massa seca.

A composição química da planta forrageira é um dos parâmetros utilizados para medir seu valor nutritivo nas pastagens (Euclides et al., 1996). Experimentos mostram que o capim-aruana tem produzido aproximadamente $15 \mathrm{Mg} \mathrm{MS} \mathrm{ha}^{-1}$ com 9,8\% de proteína bruta aos 50 dias de vegetação. Tem apresentado boa distribuição sazonal (35 a 
40 \% no "inverno"), elevada resistência ao pisoteio e ótima produção de sementes, em média $200 \mathrm{~kg} \mathrm{ha}^{-1}$ (Cunha et al., 1999).

Cecato et al. (1994) encontraram para o capim-aruana, teores de PB de 12,8 \% na estação de estabelecimento, mantendo o mesmo valor durante a estação seca com uma tendência de elevação do teor na segunda estação de chuvas. Nesta última, o capimaruana apresentava elevados teores de FDA associados a uma menor digestibilidade.

\subsection{Utilização de plantas forrageiras de inverno}

O cultivo de plantas forrageiras hibernais, que pode sanar a falta de alimento durante o período de inverno, é favorável ma condições do Estado de São Paulo, desde que sejam corrigidos os problemas de falta de água, com o uso de irrigação. Em se tratando de espécies de inverno, o seu crescimento ótimo se dá numa faixa de temperatura entre $18^{\circ} \mathrm{C}$ e $23^{\circ} \mathrm{C}$ e o aumento da taxa de acúmulo de massa seca dessas espécies hibernais apresenta alta correlação com o fotoperíodo (Moraes \& Lustosa, 1999).

Existem várias opções de espécies forrageiras que podem ser utilizadas durante o período crítico de outono/inverno, para reduzir o déficit alimentar nessa época do ano (Tabela 1). Dentre as várias alternativas de espécies forrageiras de estação fria disponíveis para amenizar a grave situação de deficiência alimentar no inverno está o cultivo de aveia (Avena sp) e azevém (Lolium multiflorum Lam.). Essas gramíneas podem ser cultivadas isoladamente ou em consórcio com outras plantas forrageiras. A aveia possui ampla adaptabilidade, permitindo seu cultivo tanto no Sul como no Centro do país. $\mathrm{O}$ azevém tem seu cultivo mais restrito às regiões de menor temperatura (Floss, 1988).

Pesquisas mostram que plantas forrageiras de clima temperado têm um grande potencial quando cultivadas no inverno, em regiões tropicais (Andrade et al., 1975; Motta et al., 1980; Guss et al., 1981; Botrel \& Novelly, 1982; Alvim \& Mozzer, 1984; Godoy et al., 1986 e Reis et al., 1993). 
Segundo Floss (1988), o estabelecimento das culturas da aveia e do azevém no Brasil Central é uma importante alternativa para o período de baixas temperaturas, limitante para as plantas forrageiras de verão. Inúmeros trabalhos de pesquisa realizados em Minas Gerais (Botrel \& Novelly, 1982; Cardoso, 1986; Alvim et al., 1987) e, também, no estado de São Paulo (Godoy et al., 1986) demonstraram a potencialidade do cultivo daquelas forrageiras no período de inverno.

Tabela 1. Principais espécies forrageiras de inverno cultivadas no Brasil

\begin{tabular}{|c|c|}
\hline Nome Científico & Nome comum \\
\hline \multicolumn{2}{|l|}{ Gramíneas anuais } \\
\hline Avena byzantina & Aveia amarela \\
\hline Avena sativa & Aveia branca \\
\hline Avena strigosa & Aveia preta \\
\hline Ḧordeum vulgare & Cevada \\
\hline Lolium multiflorum & Azevém \\
\hline Secale cereale & Centeio \\
\hline$X$ triticosecale & Triticale \\
\hline \multicolumn{2}{|l|}{ Gramíneas perenes } \\
\hline Bromus catharticus & Cevadilha \\
\hline Dactylis glomerata & Capim dos pomares \\
\hline Festuca arundinacea & Festuca \\
\hline Phalaris tuberosa & Falaris \\
\hline \multicolumn{2}{|l|}{ Leguminosas anuais } \\
\hline Lathyrus sativus & Chícharo \\
\hline Ornithopus sativus & Serradela \\
\hline Pisum arvense & Ervilha forrageira \\
\hline Vicia sativa & Ervilhaca, Vica \\
\hline Vicia villosa & Ervilhaca peluda \\
\hline Trifolium subterraneum & Trevo subterrâneo \\
\hline Trifolium vesiculosum & Trevo vesiculoso \\
\hline \multicolumn{2}{|l|}{ Leguminosas perenes } \\
\hline Lotus corniculatus & Cornichão \\
\hline Medicago sativa & Alfafa \\
\hline Trifolium pratense & Trevo vermelho \\
\hline Trifolium repens & Trevo branco \\
\hline
\end{tabular}


Segundo Reis et al. (1993), a utilização de espécies forrageiras de clima temperado, como as aveias preta (Avena strigosa), branca (Avena sativa), amarela (Avena byzantina), azevém (Lolium sp.) e alfafa (Medicago sativa), no Brasil Central tem permitido a obtenção de forragem de alta qualidade durante o "inverno".

As razões do bom desempenho animal em pastagens de espécies forrageiras de inverno estão na composição bromatológica da forragem produzida, variável conforme o estádio de desenvolvimento das plantas (Floss, 1988). A qualidade da forragem de espécies forrageiras de ciclo hibernal depende, dentre outros fatores, do manejo ao qual são submetidas na fase de produção, como irrigação, fertilização, altura e intervalo entre cortes e condições de pastejo (Cecato et al. 1998; Gomes \& Reis, 1999; Alvim \& Cóser, 2000; Restle, et al. 2000).

\subsubsection{Aveia (Avena sp)}

A classificação do gênero Avena foi definida por volta do ano de 1700, pelo francês Tournefort. Em 1750, a maioria das espécies havia sido classificada por Linnaeu (Matz, 1969). A aveia é um cereal originário da Ásia antiga, encontrada como invasora do trigo e cevada, representando uma cultura muito importante para os agricultores primitivos. Dessa região passou para a Europa, cujas condições de solo e clima permitiram expansão da cultura, tornando-se importante fonte para alimentação humana e animal (Floss, 1988).

A aveia se adapta a diferentes regiões de climas temperados ou subtropicais, sendo que temperaturas acima de $32^{\circ} \mathrm{C}$, na época de floração, provocam esterilidade. Em regiões com temperaturas e umidade relativa altas a cultura está sujeita a ataques severos da ferrugem da folha. Quanto à altitude, as aveias são cultivadas tanto no nível do mar como a 1000 m de altitude, como nos Alpes e Pirineus (Matz, 1969).

Aparentemente, as aveias requerem alto teor de umidade no solo para a formação de uma unidade de massa seca, principalmente nos estádios de florescimento até o início da formação de grãos, onde a água é requerida com maior intensidade. Entretanto, 
suporta longos períodos de deficiência hídrica, recuperando-se rapidamente (Floss, 1988).

Segundo Shands \& Cisar (1988), trata-se de uma gramínea de hábito cespitoso, com crescimento além de um metro. O sistema radicular é do tipo fasciculado, sendo as raízes fibrosas, o que facilita a penetração no solo. Os colmos são cilíndricos e eretos, compostos de nós e entrenós e relativamente cheios durante o período vegetativo. As folhas possuem bainha vilosa, lígula obtusa de 1,5 a 7,0 mm e bem desenvolvida. A inflorescência é uma panícula piramidal e difusa, apresentando espiguetas contendo um grão primário e um grão secundário e, raramente, um terciário.

Há aveias perenes e anuais. No entanto, as mais cultivadas são as anuais. São espécies de estação fria, porém apresentam cultivares adaptados a regiões de clima quente. Segundo Floss (1988), as principais espécies cultivadas no Brasil são: Avena sativa L. (branca), Avena byzantina C. Koch (amarela) e Avena strigosa Schreb (preta). Elas podem ser cultivadas isoladamente e usadas sob lotação contínua, ou em consórcio com outras espécies forrageiras.

De maneira geral, observa-se que a espécie de aveia mais utilizada como planta forrageira de inverno é a aveia preta, por apresentar maior produção de forragem em relação às aveias branca e amarela.

Quando a utilização da aveia é feita através de pastejo, recomenda-se o método de pastejo rotativo ou o pastejo controlado, sendo que no rotativo pode-se iniciar o pastejo quando o dossel forrageiro atingir $20-25 \mathrm{~cm}$ de altura (Monteiro et al., 1996). Reis et al. (1993) mostraram que $95 \%$ do material vegetal da aveia preta, com 60 dias de crescimento, era constituído por folhas, com teor médio de proteína bruta igual a $23 \%$.

As aveias apresentam área de cultivo superior à do azevém, sendo a aveia preta a mais utilizada, devido à sua elevada produção de forragem verde e seca, precocidade e maior resistência a doenças e ao pisoteio (Floss, 1988). Mesmo sendo uma gramínea de clima temperado, pode ser cultivada em regiões de clima tropical, produzindo forragem de alto valor nutritivo e possibilitando alimento de ótima qualidade durante a época de escassez de forragem (Motta et al.,1980). 
Segundo Cardoso et al. (1972), é possível obter produções de forragem de aveia, no período frio e seco do ano, nas condições do Brasil Central. Todavia, o seu cultivo deve ser feito em áreas de alta fertilidade e de fácil acesso à irrigação. Com relação a esses dois aspectos, Vilela et al. (1970) constataram que a produção de massa seca da aveia, em três cortes, foi de 6,79 $\mathrm{Mg} \mathrm{MS} \mathrm{ha}^{-1}$, quando adubada e irrigada. Primavesi (1998) obteve resultados médios de 5,12 $\mathrm{Mg} \mathrm{MS} \mathrm{ha}^{-1}$ de aveia preta, adubada e irrigada, durante o período de "inverno" no município de São Carlos, SP.

Em uma avaliação de aveia, sob pastejo, Floss (1988) observou que o consumo dos animais e o ganho de peso foram maximizados quando a forragem ofertada foi de 1,50 $\mathrm{Mg} \mathrm{MS} \mathrm{ha}^{-1}$.

A aveia, em sua fase de crescimento vegetativo, tem alta proporção de folhas, apresentando alto conteúdo de proteína e minerais, e baixo teor de fibra e lignina (Vilela et al., 1978). Cecato et al. (1998) encontraram elevados teores de proteína bruta (17 a $23 \%$ ) e baixos teores de fibra em detergente ácido (27 a $34 \%$ ) para a aveia preta.

\subsubsection{Azevém anual (Lolium multiflorum Lam.)}

O azevém anual é originário da região mediterrânea (Europa, Ásia, Norte da África), tendo sido introduzido e selecionado na Itália, América do Sul e Austrália (Monteiro et al., 1996). É uma gramínea anual de ciclo hibernal, cespitosa, que possui folhas finas e tenras. As folhas do azevém anual são mais brilhantes, sendo que, nas variedades tetraplóides, a coloração é mais escura e são mais longas. É uma planta rústica e agressiva, que produz muitos perfilhos (Floss, 1988).

O genêro Lolium apresenta duas espécies de larga distribuição no Sul do Brasil. O azevém perene (Lolium perene L.) é uma importante invasora de culturas de inverno, ocorrendo também espontaneamente em pastagens nativas e cultivadas. $\mathrm{O}$ azevém anual, italiano ou cultivado (Lolium multiflorum Lam.), é a espécie mais importante, sendo a segunda espécie forrageira mais cultivada no estado do Rio Grande do Sul, durante o inverno (Floss, 1988). 
O azevém anual, apesar de ser muito utilizado na região Sul do Brasil, é pouco conhecido no Brasil Central. Sua maior taxa de acúmulo de massa seca verifica-se durante o período de outono-inverno, e sua forragem é de alta qualidade (Alvim \& Mozzer, 1984). Como para a aveia, a utilização do azevém na produção animal pode ser realizada de várias formas: forragem verde, conservada ou cobertura de solo (Floss, 1988).

O azevém consagroutse como grande opção de pastagem de inverno, isto pela sua facilidade de ressemeadura natural, resistência a doenças, produção de sementes e versatilidade em associações com outras gramíneas e leguminosas. Apresenta produção de forragem mais tardiamente que a aveia, sendo sua maior produção nos meses de agosto e setembro, podendo chegar a produzir $70 \%$ de sua forragem durante este período (Moraes \& Lustosa, 1999).

\subsubsection{Trevo branco (Trifolium repens L.)}

O trevo branco é uma leguminosa perene de clima temperado e com adaptação ao subtrópico. Apresenta excelentes características agronômicas, tais como: produção de forragem com alta qualidade, habilidade para competir com gramíneas perenes e, entre os trevos, é o que apresenta maior capacidade de fixação de nitrogênio. Em associação com gramíneas, o seu uso é o mais difundido no mundo, contribuindo para formação de excelentes pastagens. Apresenta hábito de crescimento prostrado, com grande quantidade de estolões que enraízam nos nós, característica que lhe permite grande persistência sob pastejo (Monteiro et al., 1996).

Entre as leguminosas perenes de inverno, o trevo branco ocupa lugar de destaque, sendo crescente o seu cultivo no Sul do Brasil. Isso se deve ao seu excelente valor nutritivo, sua boa associação com gramíneas e a sua alta persistência em condições de pastejo (Moraes \& Lustosa, 1999).

Pelo seu hábito de crescimento (estolões prostrados), o trevo branco suporta altas lotações e pastejos baixos, o que muitas vezes o leva a predominar nas pastagens 
consorciadas com gramíneas e outras leguminosas de porte ereto, quando submetidas a rebaixamento excessivo (Monteiro et al., 1996).

\subsection{Introdução de espécies forrageiras de inverno em pastagens estabelecidas}

Com a intensificação e a necessidade de maior competitividade na produção animal sob pastejo, a necessidade por novas tecnologias aumenta e sua correta aplicação assume papel fundamental para a sobrevivência dos sistemas de produção (Roso et al., 1999). Sistemas de produção em pastagens, que associem espécies temperadas e tropicais numa mesma área, estão em uso pelos produtores, embora sejam poucos os resultados de pesquisa (Moraes \& Lustosa, 1999).

As misturas de espécies forrageiras anuais de inverno visam combinar os picos de produção de massa seca que são atingidos em diferentes épocas, de acordo com a espécie, resultando no aumento da produção e do período de utilização da pastagem (Roso et al., 1999), além da melhoria da qualidade da forragem ofertada aos animais (Reis, et al., 1993; Reis et al., 2001).

Lupatini et al. (1998a) destacaram como melhores misturas de espécies forrageiras de inverno as pastagens de aveia preta mais azevém, com uma produção igual a 5,95 Mg MS ha- ${ }^{-1}$ e as pastagens de aveia preta mais azevém mais cornichão mais trevo branco com $6,70 \mathrm{Mg} \mathrm{MS} \mathrm{ha}^{-1}$.

Muitas das espécies forrageiras de inverno têm crescimento mais ativo no final do inverno/primavera, representando uma limitação quanto à sua utilização, em resposta à redução do déficit de forragem, normalmente já instalado no final do outono e início do inverno (Moraes \& Lustosa, 1999). Dentro desse panorama, pode-se usar a mistura de cereais de estação fria, como centeio e aveias, que são materiais mais precoces, com azevém, que é um material mais tardio, características essas que podem ser consideradas quando se visa obter forragem ao longo de todo o período hibernal (Postiglioni, 1982).

Roso et al. (1999) avaliaram a introdução da mistura aveia preta $\left(65 \mathrm{~kg} \mathrm{ha}^{-1}\right)$ mais azevém (30 $\mathrm{kg} \mathrm{ha}^{-1}$ ), semeadas a lanço, sobre uma área de gramíneas de ciclo anual, no 
município de Santa Maria-RS, e obtiveram as seguintes taxas médias de acúmulo diário de massa seca ( $\mathrm{kg} \mathrm{MS} \mathrm{ha}{ }^{-1}$ ) distribuídas nos períodos de 08/06 a 30/06 (63,4); 01/07 a 31/07 (56,8); 01/08 a 31/08 (51,1); 01/09 a 30/09 (54,4); 01/10 a 31/10 (57,9) e 01/11 a 14/11 (50,4). Esses dados revelaram a influência da época do ano sobre a taxa de acúmulo de massa seca, sendo as maiores taxas relatadas para os meses de junho e julho. Estes mesmos autores determinaram o percentual de cada componente forrageiro presente, observando a maior participação inicial da aveia preta $(89,5 \% ; 77,8 \% ; 16,0 \%$ e $03,7 \%$ nos meses de junho, julho, agosto e setembro, respectivamente). A partir de outubro, a aveia preta estava ausente no consórcio. Já o azevém apresentou pequena participação inicial, aumentou sua participação até setembro/outubro, declinando esta em novembro $(10,6 \% ; 22,2 \% ; 44,6 \% ; 77,7 \% ; 69,5 \%$ e 45,5 \% nos meses de junho, julho, agosto, setembro, outubro e novembro respectivamente). Essas observações concordam com a afirmação de Floss (1988) de que a aveia apresenta rápido crescimento inicial, com diminuição da produção nos períodos seguintes, e que o azevém apresenta desenvolvimento lento em temperaturas baixas e aumenta a produção de massa seca com as temperaturas mais elevadas de primavera.

No estado de São Paulo, a sobre-semeadura de espécies forrageiras de inverno em pastagens de tifton-85 proporcionou aumento na produção de forragem no início do inverno e não interferiu na recuperação do capim-tifton-85 na primavera Moreira et al., 2002).

Em pastagens com a mistura de aveia preta, azevém, cornichão e trevo branco, as leguminosas apresentaram contribuição relevante para a produção de forragem, principalmente no segundo ano, com 54,7 \% da composição botânica da mistura (Lupatini et al., 1998a).

Fribourg \& Overton (1973), trabalhando com pastagem de capim-bermuda sobresemeada com espécies de inverno, demonstraram que, em regiões subtropicais, a utilização conjunta de espécies temperadas e tropicais permitiu um prolongamento do período de pastejo durante o ano, passando de 5 a 8 meses para 9 meses, além da obtenção de maior produção de forragem por unidade de área. 
De acordo com Hodgson (1990), o manejo de uma pastagem tem como objetivo principal atender as exigências nutricionais do animal, mantendo o potencial produtivo das plantas pastejadas. A introdução de espécies de forrageiras de inverno sobre uma pastagem de capim aruana acompanhada de irrigação, adubação e manejo adequado tem como proposta melhorar o potencial produtivo e sua distribuição anual, além de atender melhor as exigências nutricionais dos animais que utilizam essa pastagem. 


\section{CARACTERÍSTICAS DO DOSSEL FORRAGEIRO E ACÚMULO DE FORRAGEM EM PASTAGEM IRRIGADA DE CAPIM -ARUANA EXCLUSIVO OU SOBRESEMEADO COM UMA MISTURA DE ESPÉCIES FORRAGEIRAS DE INVERNO}

\section{Resumo}

No Instituto de Zootecnia, Nova Odessa, SP, em uma pastagem de capim-aruana (Panicum maximum Jacq. cv. Aruana) utilizada com ovinos em sistema intensivo de produção (irrigação, adubação e lotação rotacionada), foram sobre-semeadas as espécies forrageiras de inverno: aveia preta (Avena strigosa Schreb cv. Comum), azevém anual (Lolium multiflorum Lam. cv. Comum) e trevo branco (Trifolium repens L. cv. Zapicán) com o objetivo de suprir o déficit de forragem no período crítico do ano. A sobresemeadura foi efetuada em 14/04/00 e 07/06/01 no primeiro e segundo anos do experimento, respectivamente. Nos dois anos (14/04/00 a 18/01/01 e 07/06/01 a 22/02/02) foram avaliados, em seis períodos de pastejo: massa total de forragem prépastejo, sua composição botânica e porcentagem de lâminas foliares, massa de forragem remanescente pós-pastejo, acúmulo de forragem $(\mathrm{AF})$ e taxa média diária de acúmulo de forragem (TMDAF) em cada período de rebrotação e altura do dossel forrageiro pré e pós-pastejo. O delineamento experimental foi o de blocos completos casualizados (quatro), com duas repetições dentro do bloco e dois tratamentos: 1) capim-aruana exclusivo (AE) e 2) sobre-semeadura da mistura das três espécies forrageiras de inverno (MFI). Os blocos eram pastejados pelo mesmo lote de animais, em sequência, por dois a três dias, até atingir 10 a $15 \mathrm{~cm}$. No primeiro ano, a pastagem MFI apresentou maior 
massa total de forragem do que a pastagem $\mathrm{AE}$ no segundo período e na média dos seis períodos de pastejo. A aveia apresentou a maior contribuição no segundo período e o azevém no terceiro. As pastagens com a MFI apresentaram maiores AF e TMDAF que as pastagens de $\mathrm{AE}$ no segundo, quinto e na média dos seis períodos de rebrotação. No segundo ano, a massa total de forragem apresentou quantidades semelhantes entre as duas pastagens ao longo dos seis períodos de pastejo e na sua média. A aveia esteve mais presente no primeiro período e o azevém no terceiro. Não houve diferença entre tipos de pastagem para AF e TMDAF em nenhum dos seis períodos de rebrotação, nem na sua média. Para o componente aruana a porcentagem de lâminas foi semelhante entre os dois tipos de pastagem e para a aveia e azevém, as menores porcentagens ocorreram no período final dos seus ciclos vegetativos, em ambos os anos. Pastos de capim-aruana adubados e irrigados, que recebam sobre-semeadura com espécies forrageiras de inverno, produzem mais forragem no período crítico, em relação a pastos não sobresemeados, nas condições do Estado de São Paulo. Pastos desse capim, não sobresemeados, mas que recebam esses mesmos tratos apresentam boa produção.

\section{Summary}

At Instituto de Zootecnia, Nova Odessa, SP, in a pasture of aruanagrass (Panicum maximum Jacq. cv. Aruana), grazed by sheep in an intensive production system (irrigation, fertilization and rotational stocking), it was introduced a three winter forage species: black oat (Avena strigosa Schreb. cv. Common), italian ryegrass (Lolium multiflorum Lam. cv. Common) and white clover (Trifolium repens L. cv. Zapican) with the objective of increasing the forage supply during the dry winter period. The mixture was broadcasted sown over the grass on 04-14-00 and 06-07-01 in two years of experiment. From 04-14-00 to 01-18-01 and 06-07-01 to 02-22-02 it was evaluated, in six grazing periods, the forage mass, its botanical composition and leaf blades percentage pre grazing, residual mass post grazing, forage accumulation (FA) and mean forage accumulation daily rate (MFADR) in the six regrowth periods and sward heigth pre and post grazing. The experimental design was a completely randomized blocks 
(four) with two replications within the block. The treatments were 1) grass alone and 2) the grass oversown with the mixture of the three winter forages. The blocks were grazed by the same group of sheep in sequence for two or three days until lower the height to $10-15 \mathrm{~cm}$. During the two years there was six grazing and six regrowth periods. In the first year the oversown treatment presented higher total forage mass than the control in the second period and in the mean of the six grazing periods. The black oat pesented higher contribution in the second period and italian ryegrass in the third. The oversown pastures presented higher FA and MFADR than the single aruanagrass pastures, in the second, fifth and in the mean of the six regrowth periods. In the second year, the total forage mass was similar in the two pasture treatments in all grazing periods and in their means. The black oat contribution was higher in the first period and the one of italian ryegrass in the third. The FA and the MFADR were similar in the two pasture systems. The leaf blades percentage of aruanagrass was similar in the two pastures in all periods and the ones of black oat and italian ryegrass were lower in the final period compared to the preceeding ones, in the two years. For the São Paulo State conditions, fertilized and irrigated aruanagrass pastures, when oversown with winter annual forages, yield more than single aruanagrass ones during the dry winter period. Single aruanagrass pastures when fertilized and irrigated present also good yields during this time.

\subsection{Introdução}

No Brasil, a maior parte da produção de leite e carne baseia-se na utilização de pastagens, por ser esta a forma mais econômica de fornecer alimento aos animais. Os índices de produtividade animal, nas pastagens brasileiras, ainda são considerados muito baixos em virtude do baixo nível tecnológico das explorações, conseqüência da baixa produtividade e qualidade das espécies forrageiras utilizadas, do baixo potencial produtivo do rebanho, uso de pastagens degradadas, etc, que resultam em baixo rendimento da atividade produtiva. Maiores retornos econômicos podem ser obtidos em situações em que as produções por animal e por área sejam elevadas e a relação custo/benefício do uso da tecnologia seja favorável. 
A estabilidade na produção de massa seca ao longo do ano é importante, pois facilita o manejo da pastagem evitando grandes variações na carga animal necessária para a manutenção de resíduo adequado, visando maximizar a produtividade. A oscilação que frequentemente ocorre na taxa de acúmulo de massa seca das pastagens, devido às variações climáticas e à estacionalidade de produção das espécies utilizadas, é a maior dificuldade enfrentada no manejo das pastagens (Roso et al., 1999). Assim, a baixa produtividade das pastagens tropicais durante o "inverno" (escassez de chuvas associada a baixas temperaturas) no Brasil Central é uma das causas que mais contribui para a baixa produtividade dos rebanhos nas pastagens. A introdução de misturas de espécies forrageiras de ciclo hibernal, nas pastagens de gramíneas tropicais, visam combinar os picos de produção de massa seca que são atingidos em diferentes épocas, para cada espécie, resultando em aumento da produção e do período de utilização da pastagem (Fribourg \& Overton, 1973; Postiglioni, 1982; Johnson \& Lee, 1997; Lupatini et al., 1998a; Roso et al., 1999; Reis \& Fontaneli, 2000). Isto seria uma alternativa para explorar sistemas tropicais que tenham menor dependência da utilização de forragens conservadas e concentrados.

O cultivo de plantas forrageiras hibernais, que pode sanar a escassez de alimento durante o período de inverno, é favorável nas condições do Estado de São Paulo, desde que sejam corrigidos os problemas de falta de água, com o uso de irrigação (Moraes \& Lustosa, 1999). Sistemas de produção em pastagem, que associem espécies temperadas e tropicais numa mesma área estão em uso pelos produtores, embora sejam poucos os resultados de pesquisa (Reis et al., 1993, Moraes \& Lustosa, 1999, Reis et al., 2001).

O cultivar auana foi lançado pelo Instituto de Zootecnia em 1989, sob o no IZ-5, como uma opção para formação de pastagens. É proveniente da África, tendo vindo para Nova Odessa através de sementes trazidas do km 47 (Universidade Federal Rural do Rio de Janeiro) onde foi introduzido pelo Doutor Jorge Ramos Otero (Instituto de Zootecnia, 1989). Experimentos de Cunha et al. (1999) mostraram que o capim-aruana tem produzido aproximadamente $15 \mathrm{Mg} \mathrm{MS} \mathrm{ha}^{-1}$ com 9,8\% de proteína bruta aos 50 dias de vegetação, com boa distribuição sazonal (35 a 40 \% no "inverno"). Ghisi et al. (1989), 
estudando seis cultivares de Panicum maximum Jacq., constataram que os cultivares aruana e IPEACS apresentaram a melhor distribuição anual de produção de matéria seca.

Moreira et al. (2002), trabalhando em Jaboticabal/SP com a sobre-semeadura de forrageiras de inverno em pastagens de tifton-85, sob irrigação, demonstraram que a introdução da mistura das espécies hibernais proporcionou aumento da produção de forragem, no início do inverno e não interferiu na recuperação do capim-tifton-85 na primavera.

Resultados de pesquisa com aveia preta mais azevém, sob pastejo (Lupatini et al., 1998a; Restle et al., 2000; Roso et al., 1999), demonstraram o grande potencial de produção de forragem destas espécies quando associadas entre si. No entanto, são poucas as informações sobre a dinâmica e produção de forragem de pastagens de gramíneas tropicais sobre-semeadas com gramíneas anuais de estação fria, em condições de pastejo, no Estado de São Paulo.

Este trabalho teve como objetivo avaliar o desenvolvimento vegetativo de uma pastagem de Panicum maximum Jacq. cv. Aruana, irrigada, adubada e manejada em lotação rotacionada com ovinos, na qual se introduziram simultaneamente, durante a estação de outono, três espécies forrageiras de inverno, visando a redução do déficit de produção da forragem ofertada para os animais no período crítico do ano (fim do outono/inverno/início de primavera), nas condições do Estado de São Paulo.

\subsection{Material e Métodos}

O experimento foi conduzido na unidade de ovinos do Instituto de Zootecnia, em Nova Odessa/SP, a $22^{\circ} 47^{\prime}$ de latitude (S), $47^{\circ} 18^{\prime}$ de longitude (W) e a uma altitude média de $528 \mathrm{~m}$. A precipitação pluviométrica média anual no município é de cerca de $1270 \mathrm{~mm}$, sendo que apenas $30 \%$ dessa precipitação ocorre no período de maio a setembro. 
Os dados climáticos (chuvas e temperaturas) referentes aos anos de execução do presente estudo, coletados no posto meteorológico do Instituto de Zootecnia em Nova Odessa/SP, são mostrados na Figura 1.

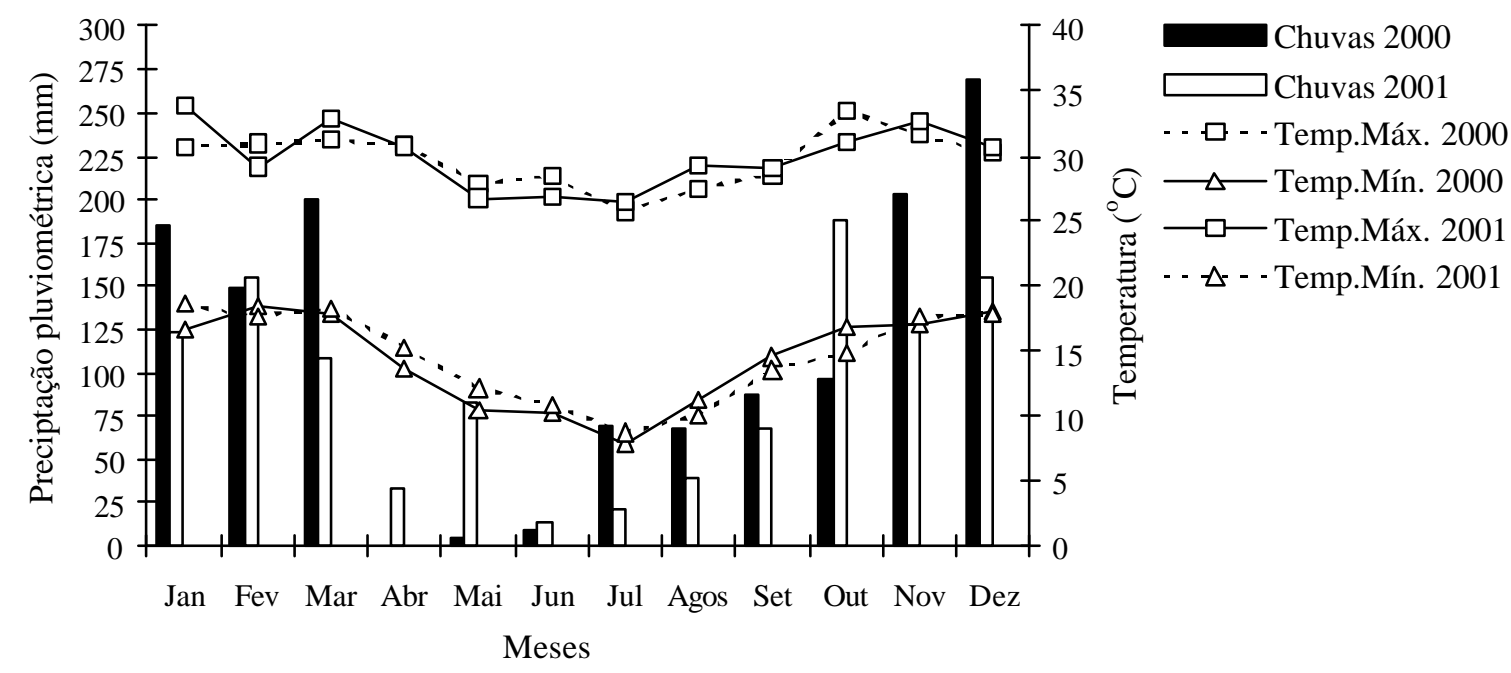

Figura 1 - Precipitações pluviométricas e temperaturas nos anos de 2000 e 2001

Aproveitourse, para a instalação do projeto, um piquete (com aproximadamente $3000 \mathrm{~m}^{2}$ ) em uma área experimental situada num solo classificado como Argissolo Vermelho-Amarelo, (EMBRAPA, 1999), constituída por 5 piquetes estabelecidos em 1991, com capim-aruana (Panicum maximum Jacq. cv. Aruana) e pastejado com ovinos em sistema intensivo de produção (irrigação, adubação e lotação rotacionada).

Em meados de janeiro de 2000 foram retiradas amostras de solo, para análises químicas, na profundidade de 0-20 cm, tomando-se 10 sub-amostras de áreas homogêneas, para constituição de uma amostra composta, de cada área homogênea.

Os resultados da análise química de solo foram os seguintes: $\mathrm{pH}(\mathrm{CaCb})=5,6$; M.O. $=28 \mathrm{~g} / \mathrm{dm}^{3} ; \mathrm{P}$ (resina) $=23 \mathrm{mg} / \mathrm{dm}^{3} ; \mathrm{K}=2,7 \mathrm{mmol} / \mathrm{dm}^{3} ; \mathrm{Ca}=37 \mathrm{mmol} / \mathrm{dm}^{3}$; $\mathrm{Mg}=10 \mathrm{mmol}_{\mathrm{c}} / \mathrm{dm}^{3} ; \mathrm{H}+\mathrm{Al}=22 \mathrm{mmol}_{\mathrm{c}} \mathrm{dm}^{3} ; \mathrm{S}=52 \mathrm{mmol} / \mathrm{dm}^{3} ; \mathrm{CTC}=74 \mathrm{mmol}_{\mathrm{c}} / \mathrm{dm}^{3} \mathrm{e}$ saturação por bases $=70 \%$. Essa análise revelou não ser necessária a aplicação de calcário, devendo ser utilizadas apenas adubações fosfatada e potássica. 
As espécies forrageiras de inverno introduzidas, simultaneamente, no pasto formado com capim-aruana foram as seguintes: aveia preta (Avena strigosa Schreb cv. Comum), azevém anual (Lolium multiflorum Lam. cv. Comum) e trevo branco (Trifolium repens L. cv. Zapicán). Esses cultivares são aqueles mais usados no Rio Grande do Sul e com sementes disponíveis no comércio.

O delineamento experimental utilizado foi o de blocos completos casualizados (em número de quatro) com duas repetições por tratamento dentro de cada bloco. Os dois tratamentos testados foram: 1) capim-aruana exclusivo, como testemunha e 2) capim-aruana sobre-semeado com uma mistura de três espécies forrageiras de inverno (aveia preta, azevém, e trevo branco), perfazendo um total de 16 parcelas experimentais de $100 \mathrm{~m}^{2}$ cada (vide croquis, Figura 2).

xxxxxxxxxxxxxxxxxxxxx Eucaliptos $x x x x x x x x x x x x x x x x x x x x x$
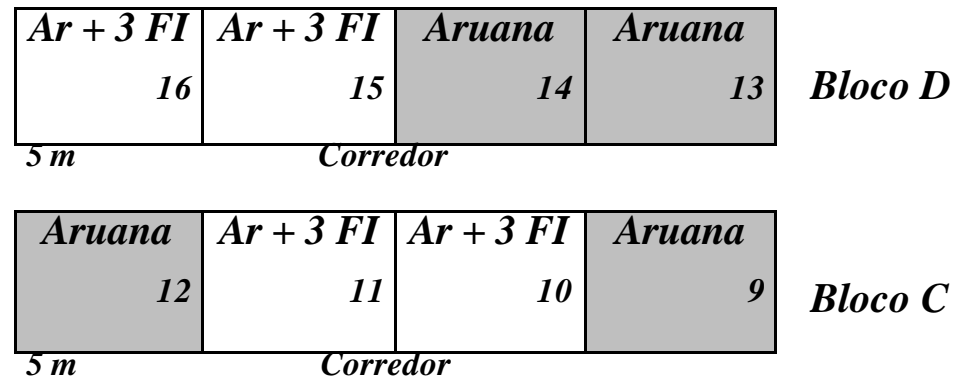

Bloco C

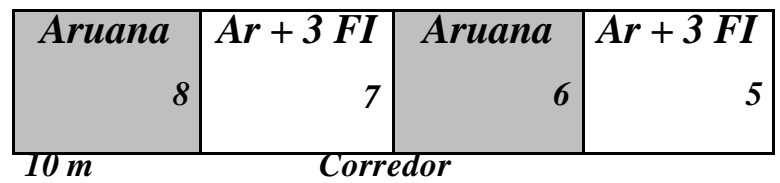

Bloco B Aruana= Aruana Exclusivo

Ar +3 FI= Aruana + mistura de 3 forrageiras de inverno

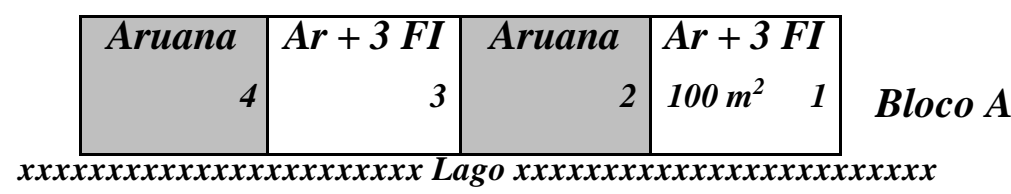

Figura 2 - Croquis da área experimental 
Para a introdução da mistura das três espécies forrageiras de inverno foi feito o rebaixamento prévio de todas as parcelas experimentais por meio de pastejo (ovinos) obtendo-se uma altura do dossel forrageiro em torno de $5 \mathrm{~cm}$. A sobre-semeadura das três espécies forrageiras de inverno, realizada a lanço, nas parcelas correspondentes a este tratamento, ocorreu em 14 de abril/2000, no primeiro ano de experimento e em 07 de junho/2001, no segundo ano, misturando-se as sementes $\left(65 \mathrm{~kg} \mathrm{ha}^{-1}\right.$ de aveia preta, 30 $\mathrm{kg} \mathrm{ha}^{-1}$ de azevém e $10 \mathrm{~kg} \mathrm{ha}^{-1}$ de trevo branco) com os adubos (40 $\mathrm{kg} \mathrm{ha}^{-1}$ de $\mathrm{P}_{2} \mathrm{O}_{5}, 42$ $\mathrm{kg} \mathrm{ha}^{-1}$ de $\mathrm{K}_{2} \mathrm{O}$ e $30 \mathrm{~kg} \mathrm{ha}^{-1}$ de FTE BR-16).

Antes da semeadura, as sementes de trevo branco foram inoculadas com BIOMAX contendo turfa esterilizada, misturada com a estirpe específica para essa espécie forrageira. Logo após a semeadura das parcelas experimentais, foi permitida uma entrada rápida dos ovinos para que o pisoteio propiciasse um melhor contato das sementes com o solo. Obteve-se uma ótima germinação das três espécies forrageiras de inverno mas, em virtude de uma rebrotação muito rápida e intensa do capim-aruana, houve um sombreamento muito grande das forrageiras de inverno, refletindo-se na ausência do componente trevo branco em todas as avaliações, no primeiro e segundo anos do experimento.

O sistema de irrigação (aspersão do tipo fixo) da pastagem foi monitorado através da instalação de quatro pares de tensiômetros, um par em cada bloco $(0-20 \mathrm{~cm}$ e 0-40 cm de profundidade) onde eram realizadas leituras periódicas para manter a tensão na faixa de 0,3 a 0,4 bar $(22,8 \mathrm{~cm} \mathrm{Hg}$ a $30,4 \mathrm{~cm} \mathrm{Hg})$. No segundo ano do experimento houve limitação no sistema de irrigação oriunda do baixo nível de água da represa de captação pelo sistema de aspersão, fornecendo assim, uma quantidade de água inferior à desejada. A queda no volume das chuvas, durante os meses de julho a agosto (Figura 1), foi crítica para o cultivo das espécies hibernais.

Em novembro/2000, foi feita uma adubação nitrogenada (50 kg ha ${ }^{-1}$ de $\mathrm{N}$ ) e potássica $\left(50 \mathrm{~kg} \mathrm{ha}^{-1}\right.$ de $\left.\mathrm{K}_{2} \mathrm{O}\right)$ nas parcelas experimentais. Em março/2001 foi feita a adubação nitrogenada no final das águas, aplicando-se $100 \mathrm{~kg} \mathrm{ha}^{-1} \mathrm{de} \mathrm{N} \mathrm{e}$, em meados de outubro/2001, início das águas, foram aplicados $50 \mathrm{~kg} \mathrm{ha}^{-1} \mathrm{de} \mathrm{N}$. 
A área experimental foi dividida em faixas, delimitadas por cerca elétrica no momento do pastejo. As faixas (blocos) eram pastejadas em sequiência, por dois a três dias, pelo mesmo lote de ovinos, simultaneamente nas parcelas do capim-aruana exclusivo (testemunha) e nas da mistura das espécies forrageiras de inverno introduzidas sobre o capim. No primeiro ano experimental (14/04/00 a 18/01/01) ocorreram seis períodos de pastejo (P): P1: 24/05 a 01/06/00, P2: 04/07 a 12/07/00, P3: 30/08 a 05/09/00, P4: 18/10 a 26/10/00, P5: 06/12 a 20/12/00 e P6: 09/01 a 18/01/01 precedidos por seis períodos de rebrotação (R), com aproximadamente 40, 39, 55, 47, 46 e 32 dias, respectivamente. No segundo ano experimental (07/06/01 a 22/02/02) também houve seis períodos de pastejo (P): P1: 27/07 a 06/08/01, P2: 06/09 a 16/09/01, P3: 22/10 a 02/11/01, P4: 26/11 a 11/12/01, P5: 02/01 a 14/01/02 e P6: 06/02 a 22/02/02 e seis períodos de rebrotação (R), em torno de 50, 39, 43, 32, 34 e 30 dias respectivamente.

As amostragens eram feitas em quatro pontos por parcela, através do lançamento ao acaso de um quadrado de $0,25 \mathrm{~m}^{2}$, perfazendo um total de $1 \mathrm{~m}^{2}$, para se avaliar na massa de forragem, antes da entrada dos animais (pré-pastejo), as características agronômicas da pastagem (quantidade da massa seca total de forragem e de cada componente botânico - composição botânica). Após a saída dos animais (póspastejo), avaliava-se a forragem remanescente (quantidade da massa seca de forragem residual) pelo mesmo procedimento. O acúmulo de forragem (AF) em cada período de pastejo foi calculado subtraindo-se, da massa de forragem pré-pastejo do período " $n$ ", a massa de forragem pós-pastejo do período "n-1". A taxa média diária de acúmulo de forragem (TMDAF) foi calculada dividindo-se o AF pelo número de dias de rebrotação da pastagem (período de descanso) referente a cada um dos seis períodos de pastejo. $\mathrm{O}$ AF do primeiro período de pastejo, em ambos os anos, foi considerado o mesmo que a massa total de forragem presente antes da entrada dos animais (pré-pastejo), pois, no início de cada ano experimental, todas as parcelas foram rebaixadas a $5 \mathrm{~cm}$ de altura para a introdução das espécies forrageiras de inverno, sendo considerado, portanto, o valor do resíduo deste pós-pastejo igual a zero.

Tanto para a forragem pré-pastejo, como para a forragem remanescente póspastejo), os cortes eram feitos rente ao solo, com tesoura de poda. A forragem 
proveniente da área amostrada $\left(1 \mathrm{~m}^{2}\right)$ de cada unidade experimental, antes da entrada dos animais, era pesada e da mesma retiradas cerca de $200 \mathrm{~g}$ (sub-amostragem), que após pesagem, secagem e novamente pesagem, era usada para estimar a massa seca total de forragem. O restante do material coletado era separado nos componentes capimaruana, plantas invasoras, material morto, aveia preta e azevém que eram pesados e amostrados para secagem e determinação dos seus teores de matéria seca (MS). Todas as amostras eram secadas em estufa de circulação forçada de ar $\left(65^{\circ} \mathrm{C}\right)$, até peso constante. Do material verde dos componentes forrageiros capim-aruana, aveia preta e azevém foi retirada outra amostra para separação de lâminas e hastes que, após secagem, na estufa, eram pesadas para obtenção da variável porcentagem de lâminas. A forragem remanescente proveniente da amostra composta dos quatro pontos, após a saída dos animais, era pesada e amostrada (cerca de $200 \mathrm{~g}$ ), para secagem, determinação dos seus teores de MS e cálculo da massa seca de forragem residual.

No momento de executar cada amostragem, media-se também a altura das plantas (com régua, na distância do solo ao topo do dossel forrageiro). Esta altura era medida ao lado dos quatro pontos atingidos aleatoriamente pelo quadrado usado na amostragem da forragem, antes da entrada dos animais e da forragem remanescente.

Os dados foram analisados através dos procedimentos MIXED e medidas repetidas no tempo (Repeated Measures) (Littell et al., 1996), do programa SAS ${ }^{\circledR}$ (Statistical Analysis System), SAS Institute (1990), a fim de se determinar a estrutura de matriz de variância e covariância. O nível de significância adotado para a análise de variância foi de $10 \%$. Para os efeitos significativos, foram realizados testes de comparação de médias, através do procedimento LSMEANS, com um nível de significância de $10 \%$. As interações significativas foram desdobradas de acordo com os fatores envolvidos. 


\subsection{Resultados e Discussão}

\subsubsection{Primeiro Ano Experimental - Massa de forragem e dos componentes botânicos, acúmulo de forragem e taxa média diária de acúmulo de forragem, altura do dossel forrageiro e porcentagens de lâminas foliares}

$\mathrm{Na}$ Tabela 2 são apresentados os dados referentes à massa de forragem e componentes botânicos (aruana, invasoras, material morto, aveia preta e azevém) no dossel forrageiro de pastagens de capim-aruana exclusivo e capim-aruana sobresemeado com a mistura de aveia preta e azevém, em seis períodos de pastejo, no primeiro ano de execução do experimento.

Houve diferenças significativas entre tipos de pastagem $(P=0,0652)$ quanto à massa total de forragem, quando se considerou a média dos seis períodos de pastejo, obtendo-se os valores de 4,22 e 3,75 $\mathrm{Mg} \mathrm{MS} \mathrm{ha-1} \mathrm{para} \mathrm{a} \mathrm{pastagem} \mathrm{MFI} \mathrm{e} \mathrm{AE,}$ respectivamente. A interação períodos de pastejo $\mathrm{x}$ tipos de pastagem também foi significativa $(P=0,1000)$, ocorrendo diferença significativa entre os dois tratamentos apenas no segundo período.

Fribourg \& Overton (1973), trabalhando com pastagem de capim-bermuda sobresemeada com espécies de inverno, demonstraram que, em regiões subtropicais, a utilização conjunta de espécies temperadas e tropicais proporcionou maior massa de forragem por unidade de área, coincidindo com os resultados deste experimento.

Para o componente aruana (Tabela 2), a interação períodos de pastejo x tipos de pastagem foi significativa $(P=0,0230)$. Nos períodos $P 1(24 / 05$ a $01 / 06 / 00), P 2(04 / 07$ a 12/07/00), P3 (30/08 a 05/09/00) e P6 (09/01 a 18/01/01) o componente aruana apresentou massas de forragem semelhantes nos dois tipos de pastagem. No P4 (18/10 a 26/10/00) houve maior presença do componente aruana na pastagem de capim aruana exclusivo, invertendo esta situação no P5 (06/12 a 20/12/00), onde o componente aruana apresentou-se em maior proporção na pastagem contendo a mistura de espécies forrageiras de inverno. 
Tabela 2. Massa de forragem e componentes botânicos no dossel forrageiro de pastagens de capim-aruana exclusivo (AE) e capim-aruana sobre-semeado com uma mistura de espécies forrageiras de inverno (MFI) antes da entrada dos ovinos em seis períodos de pastejo $(\mathrm{P})$ no primeiro ano do experimento

\begin{tabular}{|c|c|c|c|c|c|c|c|}
\hline \multirow{4}{*}{$\begin{array}{l}\text { Tipos de } \\
\text { Pastagem }\end{array}$} & \multicolumn{7}{|c|}{ Períodos de Pastejo } \\
\hline & P1 & P2 & P3 & P4 & P5 & P6 & Média* \\
\hline & $24 / 05$ a & $04 / 07 \mathrm{a}$ & $30 / 08$ a & $18 / 10$ a & $06 / 12 \mathrm{a}$ & $09 / 01$ a & \\
\hline & $01 / 06 / 00$ & $12 / 07 / 00$ & $05 / 09 / 00$ & $26 / 10 / 00$ & $20 / 12 / 00$ & $18 / 01 / 01$ & \\
\hline \multicolumn{8}{|c|}{ Total $\left(M g M S h a^{-1}\right)$} \\
\hline MFI & $3,70^{\mathrm{a}}$ & $3,03^{\mathrm{a}}$ & $2,56^{\mathrm{a}}$ & $4,22^{\mathrm{a}}$ & $7,17^{\mathrm{a}}$ & $4,65^{\mathrm{a}}$ & $4,22^{\mathrm{a}}$ \\
\hline $\mathrm{AE}$ & $3,77^{\mathrm{a}}$ & $1,97^{\mathrm{b}}$ & $2,30^{\mathrm{a}}$ & $4,28^{\mathrm{a}}$ & $6,02^{\mathrm{a}}$ & $4,15^{\mathrm{a}}$ & $3,75^{b}$ \\
\hline \multicolumn{8}{|c|}{ Aruana $\left(M g M S h a^{-1}\right)$} \\
\hline MFI & $2,17^{\mathrm{a}}$ & $1,97^{\mathrm{a}}$ & $1,23^{\mathrm{a}}$ & $2,69^{\mathrm{b}}$ & $6,17^{\mathrm{a}}$ & $3,35^{\mathrm{a}}$ & $2,93^{\mathrm{a}}$ \\
\hline $\mathrm{AE}$ & $2,67^{\mathrm{a}}$ & $1,44^{\mathrm{a}}$ & $1,66^{\mathrm{a}}$ & $3,70^{\mathrm{a}}$ & $5,05^{b}$ & $3,26^{\mathrm{a}}$ & $2,96^{\mathrm{a}}$ \\
\hline \multicolumn{8}{|c|}{ Invasoras (Mg MS ha-1) } \\
\hline MFI & $0,57^{\mathrm{a}}$ & $0,25^{\mathrm{a}}$ & $0,11^{\mathrm{a}}$ & $0,44^{\mathrm{a}}$ & $0,45^{\mathrm{a}}$ & $0,60^{\mathrm{a}}$ & $0,40^{\mathrm{a}}$ \\
\hline $\mathrm{AE}$ & $0,35^{\mathrm{a}}$ & $0,14^{\mathrm{a}}$ & $0,10^{\mathrm{a}}$ & $0,12^{b}$ & $0,45^{\mathrm{a}}$ & $0,20^{\mathrm{b}}$ & $0,23^{\mathrm{b}}$ \\
\hline \multicolumn{8}{|c|}{ Material morto (Mg MS $\left.h a^{-1}\right)$} \\
\hline MFI & $0,65^{\mathrm{a}}$ & $0,55^{\mathrm{a}}$ & $0,51^{\mathrm{a}}$ & $0,61^{\mathrm{a}}$ & $0,53^{\mathrm{a}}$ & $0,66^{\mathrm{a}}$ & $0,59^{\mathrm{a}}$ \\
\hline $\mathrm{AE}$ & $0,74^{\mathrm{a}}$ & $0,39^{\mathrm{a}}$ & $0,55^{\mathrm{a}}$ & $0,46^{\mathrm{a}}$ & $0,52^{\mathrm{a}}$ & $0,59^{\mathrm{a}}$ & $0,54^{\mathrm{a}}$ \\
\hline \multicolumn{8}{|c|}{ Aveia preta (Mg MS ha-1) } \\
\hline MFI & $0,13^{\mathrm{B}}$ & $0,20^{\mathrm{A}}$ & $0,12^{\mathrm{B}}$ & - & - & - & 0,150 \\
\hline \multicolumn{8}{|c|}{ Azevém $\left(M g M S h a^{-1}\right)$} \\
\hline MFI & $0,15^{\mathrm{C}}$ & $0,15^{\mathrm{C}}$ & $0,61^{\mathrm{A}}$ & $0,38^{\mathrm{B}}$ & - & - & 0,305 \\
\hline
\end{tabular}

Provavelmente a menor contribuição do componente aruana na pastagem do capim-aruana sobre-semeada com as forrageiras de inverno, no quarto período de pastejo, se deva ao fato da ocorrência de competição refletida no capim em razão das maiores participações dos componentes plantas invasoras $(P=0,0839)$ e material morto 
$(P=0,0452)$. Além do mais, nesse período, houve a presença do componente azevém, já no final de seu ciclo de crescimento.

Resultados semelhantes foram encontrados por Roso et al. (1999) em que, acompanhando a queda na participação dos componentes forrageiros (triticale, aveia preta e azevém) do tratamento contendo a mistura, houve grande participação de material morto e invasoras.

As plantas invasoras (Tabela 2), na média dos seis períodos de pastejo, tiveram maior presença na pastagem sobre-semeada $(P=0,0870)$. A interação período de pastejo $\mathrm{x}$ tipo de pastagem foi significativa $(P=0,0988)$. Nos períodos quatro e seis ( $\mathrm{P} 4$ : $18 / 10$ a 26/10/00 e P6: 09/01 a 18/01/01), a pastagem sobre-semeada apresentou maiores quantidades de invasoras $(10,5$ e $12,8 \%$ da massa total de forragem, respectivamente para P4 e P6) não interferindo, entretanto, na massa total de forragem de ambos os tratamentos, que permaneceram semelhantes.

Não houve diferença $(P=0,3165)$ entre os dois tipos de pastagem em qualquer período de pastejo, nem na média do experimento, para o componente botânico material morto (Tabela 2). A contribuição desse componente foi de $13,8 \%$ e $14,4 \%$ da massa total de forragem na média dos seis períodos, para pastagens sobre-semeada e exclusiva, respectivamente.

A aveia (Tabela 2) teve contribuição relativamente baixa nas três amostragens em que esteve presente. A contribuição maior $(P=0,0001)$ desse componente foi no segundo período (em julho 6,5 \%) de avaliação, decrescendo $(P=0,0001)$ sua produção no terceiro (4,7 \% em agosto) e desaparecendo a partir dessa época. Esta diminuição da massa de forragem, do segundo para o terceiro período de pastejo, coincide com os resultados de Floss (1988) e Moraes \& Lustosa (1999).

O azevém (Tabela 2) apresentou baixa presença no primeiro e segundo períodos (4,0 \% em maio e 5,0 \% em julho, respectivamente). Mostrou contribuição expressiva no terceiro período $(24,0 \%$ em setembro). Decresceu sua presença no quarto período (8,9 \% em outubro), estando ausente no quinto e sexto períodos. Esses resultados, concordam com a afirmação de Lupatini et al. (1998a), na qual o azevém apresenta desenvolvimento lento em temperaturas baixas e aumenta a produção de massa seca com 
as temperaturas mais elevadas. Portanto, pressupõe-se, no presente trabalho, que a contribuição dessas espécies hibernais, apesar de produzir quantidades pouco expressivas, seja responsável pela maior massa de forragem do tratamento aruana sobresemeado em relação ao exclusivo.

Roso et al. (1999) avaliando a introdução da mistura aveia preta mais azevém sobre uma área de gramíneas de ciclo anual, mostraram a influência da época do ano sobre a presença das forrageiras de inverno, sendo que nas médias dos tratamentos, os meses de junho e julho apresentaram as maiores contribuições, confrontando com os resultados deste experimento, que apresentaram as maiores proporções da mistura de espécies forrageiras de inverno nos meses de setembro $(29,0 \%)$.

Os dados de massa de forragem remanescente das pastagens sobre-semeda e exclusiva de capim-aruana, ao longo dos seis períodos de pastejo, estão apresentados na Tabela 3.

Tabela 3. Massa de forragem remanescente após a saída dos ovinos das pastagens de capim-aruana exclusivo (AE) e capim-aruana sobre-semeado com uma mistura de espécies forrageiras de inverno (MFI) em seis períodos de pastejo (P) no primeiro ano do experimento

\begin{tabular}{|c|c|c|c|c|c|c|c|}
\hline \multirow{4}{*}{$\begin{array}{l}\text { Tipos de } \\
\text { Pastagem }\end{array}$} & \multicolumn{7}{|c|}{ Períodos de Pastejo } \\
\hline & P1 & $\mathrm{P} 2$ & P3 & $\mathrm{P} 4$ & P5 & P6 & Média* \\
\hline & $24 / 05$ a & 04/07 a & $30 / 08$ a & $18 / 10 \mathrm{a}$ & $06 / 12 \mathrm{a}$ & 09/01 a & \\
\hline & $01 / 06 / 00$ & $12 / 07 / 00$ & $05 / 09 / 00$ & 26/10/00 & 20/12/00 & $18 / 01 / 01$ & \\
\hline \multicolumn{8}{|c|}{ Forragem remanescente - $\left(M g M S h a^{-1}\right)$} \\
\hline MFI & $1,41^{\mathrm{a}}$ & $1,25^{\mathrm{a}}$ & $1,15^{\mathrm{a}}$ & $2,14^{\mathrm{a}}$ & $2,60^{\mathrm{a}}$ & $2,75^{\mathrm{a}}$ & $1,89^{\mathrm{a}}$ \\
\hline $\mathrm{AE}$ & $1,36^{\mathrm{a}}$ & $1,24^{\mathrm{a}}$ & $1,14^{\mathrm{a}}$ & $2,28^{\mathrm{a}}$ & $2,76^{\mathrm{a}}$ & $2,56^{\mathrm{a}}$ & $1,88^{\mathrm{a}}$ \\
\hline
\end{tabular}

As massas residuais, nos seis períodos de pastejo, foram semelhantes $(\mathrm{P}>0,10)$ nos dois tipos de pastagem. Os maiores resíduos deixados nas duas pastagens (Tabela 3), na primavera/verão (P4 a P6), podem ser atribuídos às menores proporções de lâminas foliares do componente aruana (Tabela 6), resultando em maiores proporções da fração 
haste, que pode ter influenciado a ingestão de forragem pelos animais. Roso et al. (1999) encontraram os maiores teores de proteína bruta no início da utilização da pastagem, devido ao grande percentual de folhas presente no resíduo, ocorrendo redução acentuada nas avaliações seguintes, causada por aumento na quantidade de colmos e diminuição da área foliar ocasionada pelo pastejo.

Na Tabela 4 são apresentados os dados de acúmulo de forragem (AF) e da taxa diária de acúmulo de forragem (TMDAF) das pastagens de capim-aruana exclusivo e do capim-aruana sobre-semeado com a mistura das espécies hibernais, em seis períodos de rebrotação das pastagens $(\mathrm{R})$, no primeiro ano de execução do experimento. A interação períodos de rebrotação $\mathrm{x}$ tipos de pastagem para o acúmulo de forragem foi significativa $(P=0,0184)$. As pastagens sobre-semeadas com a MFI acumularam mais $(\mathrm{P}<0,10)$ forragem do que as pastagens de AE no segundo (R2: 26/05 a 04/07/00) e quinto (R5: 21/10 a 06/12/00) períodos de rebrotação, mantendo acúmulos semelhantes $(\mathrm{P}>0,10)$ nos demais períodos. Houve diferenças entre tipos de pastagem quanto ao acúmulo de forragem, quando se considerou a média dos seis períodos de rebrotação, obtendo-se os maiores valores de $\mathrm{AF}(P=0,005)$ na pastagem contendo a MFI.

No segundo período de pastejo ocorreu a contribuição de $10 \%$ dos componentes forrageiros de inverno na pastagem sobre-semeada (Tabela 2), sendo que os outros componentes botânicos dessa pastagem foram semelhantes $(\mathrm{P}>0,10)$ aos da pastagem exclusiva do capim-aruana e a massa de forragem pós-pastejo no período anterior (P1) também foi semelhante $(\mathrm{P}>0,10)$ para as duas pastagens (Tabela 3). Dessa forma, o maior acúmulo de forragem no pasto contendo a MFI se deve à presença das mesmas. Já a ocorrência do maior acúmulo de forragem, no quinto período, na pastagem sobresemeada deve ser reflexo da maior $(\mathrm{P}<0,10)$ contribuição do componente aruana (Tabela 2), já que os resíduos pós-pastejo foram semelhantes $(\mathrm{P}>0,10)$ entre os dois tipos de pastagem, em todos os períodos de pastejo (Tabela 3).

Na média dos dois tipos de pastagem houve variação $(P=0,0001)$ no acúmulo de forragem entre os períodos de rebrotação (Tabela 4), tendo os maiores acúmulos ocorridos no quinto período (primavera) seguindo-se os do primeiro período (início de outono), épocas que coincidiram com boas condições climáticas (precipitações e 
temperaturas), além de, precedendo o quinto período de rebrotação, ambos os tratamentos terem recebido uma adubação de $50 \mathrm{~kg} \mathrm{ha}^{-1}$ de $\mathrm{N}$.

Tabela 4. Acúmulo e taxa média diária de acúmulo de forragem em pastagens de capimaruana exclusivo (AE) e capim-aruana sobre-semeado com uma mistura de forrageiras de inverno (MFI) em seis períodos de rebrotação (R) da pastagem no primeiro ano do experimento

\begin{tabular}{ccccccccc}
\hline \multirow{8}{*}{ Tipos de } & R1:40 dias & R2:39 dias & R3:55 dias & R4:47 dias & R5:46 dias & R6:32 dias & Média* & Total \\
Pastagem & $14 / 04 \mathrm{a}$ & $26 / 05 \mathrm{a}$ & $06 / 07 \mathrm{a}$ & $01 / 09 \mathrm{a}$ & $21 / 10 \mathrm{a}$ & $8 / 12 / 00 \mathrm{a}$ & & \\
& $24 / 05 / 00$ & $04 / 07 / 00$ & $30 / 08 / 00$ & $18 / 10 / 00$ & $06 / 12 / 00$ & $09 / 01 / 01$ & \\
\hline \multicolumn{7}{c}{ Acúmulo de forragem $(M g$} & $\left.M S h a^{-1}\right)$ & \\
MFI & $3,70^{\mathrm{a}}$ & $1,62^{\mathrm{a}}$ & $1,31^{\mathrm{a}}$ & $3,07^{\mathrm{a}}$ & $5,54^{\mathrm{a}}$ & $2,05^{\mathrm{a}}$ & $2,88^{\mathrm{a}}$ & $17,29^{\mathrm{a}}$ \\
AE & $3,77^{\mathrm{a}}$ & $0,61^{\mathrm{b}}$ & $1,06^{\mathrm{a}}$ & $3,13^{\mathrm{a}}$ & $3,21^{\mathrm{b}}$ & $1,39^{\mathrm{a}}$ & $2,19^{\mathrm{b}}$ & $13,17^{\mathrm{b}}$ \\
Média & $3,73^{\mathrm{B}}$ & $1,11^{\mathrm{D}}$ & $1,18^{\mathrm{D}}$ & $3,09^{\mathrm{C}}$ & $4,37^{\mathrm{A}}$ & $1,72^{\mathrm{D}}$ & - & - \\
EPM & 0,2415 & 0,2415 & 0,2415 & 0,2415 & 0,2573 & 0,2415 & - & -
\end{tabular}

Taxa média de acúmulo de forragem ( $\mathrm{kg} \mathrm{MS} \mathrm{ha}^{-1} \mathrm{dia}^{-1}$ )

\begin{tabular}{|c|c|c|c|c|c|c|c|c|}
\hline MFI & $84,35^{\mathrm{a}}$ & $40,87^{\mathrm{a}}$ & $24,04^{\mathrm{a}}$ & $64,87^{\mathrm{a}}$ & $113,96^{\mathrm{a}}$ & $67,96^{\mathrm{a}}$ & $66,01^{\mathrm{a}}$ & - \\
\hline $\mathrm{AE}$ & $87,60^{\mathrm{a}}$ & $15,40^{\mathrm{b}}$ & $19,48^{\mathrm{a}}$ & $66,11^{\mathrm{a}}$ & $85,11^{\mathrm{b}}$ & $45,94^{\mathrm{a}}$ & $53,27^{\mathrm{b}}$ & - \\
\hline Média & $85,98^{\mathrm{A}}$ & $28,13^{\mathrm{C}}$ & $21,76^{\mathrm{C}}$ & $65,49^{\mathrm{B}}$ & $99,53^{\mathrm{A}}$ & $56,95^{\mathrm{B}}$ & - & - \\
\hline EPM & 5,2514 & 4,2546 & 3,5069 & 6,7375 & 10,7229 & 9,2469 & - & - \\
\hline
\end{tabular}

O acúmulo total de forragem (somatória dos seis períodos de rebrotação) do primeiro ano experimental foi maior $(P=0,0160)$ na pastagem sobre-semeada em relação à pastagem exclusiva de capim-aruana, obtendo-se os seguintes valores de AF: 17, 29 Mg MS ha ${ }^{-1}$ para MFI e 13,17 Mg MS ha ${ }^{-1}$ para AE (Tabela 4). Esses resultados são da mesma magnitude que os obtidos por Postiglioni (1982) e Roso et al. (1999).

A taxa média diária de acúmulo de forragem foi diferente $(P=0,0468)$ entre os dois tipos de pastagem apenas no segundo e quinto períodos de rebrotação onde MFI foi maior que $\mathrm{AE}$, como ocorreu com $\mathrm{AF}$. Mas variaram entre os seis períodos de rebrotação $(P=0,0001)$, na média dos dois tipos de pastagem, sendo estas TMDAF maiores no primeiro e quinto períodos (início de outono e primavera) e menores no 
segundo e terceiro períodos (final de outono e inverno), como se era de esperar pelas condições de precipitação e temperatura nestes períodos além de, precedendo o quinto período, ter havido uma adubação com $50 \mathrm{~kg} \mathrm{ha}^{-1}$ de $\mathrm{N}$. Na média dos seis períodos de rebrotação das pastagens as taxas médias diárias de acúmulo de forragem foram maiores nas pastagens contendo a MFI com 66,01 $\mathrm{kg} \mathrm{MS} \mathrm{ha}^{-1} \mathrm{dia}^{-1}$ que nas pastagens AE, com $53,27 \mathrm{~kg} \mathrm{MS} \mathrm{ha}^{-1} \mathrm{dia}^{-1}$.

Roso et al. (1999) avaliaram a introdução da mistura aveia preta mais azevém, semeadas a lanço, sobre uma área de gramíneas de ciclo anual, no Sul do País, e obtiveram as seguintes taxas médias diárias de acúmulo de forragem ( $\mathrm{kg} \mathrm{MS} \mathrm{ha}{ }^{-1}$ ) distribuídas nos períodos de 08/06 a 30/06 (63,4); 01/07 a 31/07 (56,8); 01/08 a 31/08 (51,1); 01/09 a 30/09 (54,4); 01/10 a 31/10 (57,9) e 01/11 a 14/11 (50,4), coincidindo as épocas do ano de maiores taxas diárias de acúmulo de forragem com aquelas ocorridas no presente trabalho.

A altura do dossel forrageiro (Tabela 5) antes da entrada dos ovinos na pastagem foi influenciada pela mistura das espécies forrageiras de inverno. Pastos MFI apresentaram maior altura de dossel $(P=0,0678)$ que pastos de aruana exclusivo, quando se comparou a média dos seis períodos de pastejo (MFI= $58 \mathrm{~cm}$ e $\mathrm{AE}=53 \mathrm{~cm}$ ). Mas foi apenas no terceiro período de pastejo que estatisticamente a altura da pastagem com a MFI $(49 \mathrm{~cm})$ foi maior $(P=0,0725)$, comparada com a do AE $(41 \mathrm{~cm})$. Pressupõe-se que a contribuição de $24,0 \%$ do azevém adicionado aos $5 \%$ da aveia preta, ambas em estádios avançados de desenvolvimento, tenha sido responsável pela maior altura do dossel forrageiro dos pastos consorciados, neste terceiro período.

As alturas do dossel forrageiro, após a saída dos ovinos, foram semelhantes $(P=0,4500)$ entre as duas pastagens, em todos os períodos de avaliação e na sua média (Tabela 5).

Para a porcentagem de lâminas do componente aruana, não houve diferença entre os dois tipos de pastagem em estudo $(P=0,4622)$, antes da entrada dos ovinos nos pastos (Tabela 6). 
Tabela 5. Altura do dossel forrageiro antes da entrada e após a saída dos ovinos nas pastagens de capim-aruana exclusivo (AE) e capim-aruana sobre-semeado com uma mistura de espécies forrageiras de inverno (MFI) em seis períodos de pastejo $(\mathrm{P})$ no primeiro ano do experimento

\begin{tabular}{|c|c|c|c|c|c|c|c|}
\hline \multirow[b]{2}{*}{ Tipos de } & \multicolumn{7}{|c|}{ Períodos de pastejo } \\
\hline & $\mathrm{P} 1$ & $\mathrm{P} 2$ & P3 & $\mathrm{P} 4$ & P5 & P6 & Média* \\
\hline \multirow[t]{3}{*}{ Pastagem } & $24 / 05 \mathrm{a}$ & $04 / 07$ a & $30 / 08$ a & $18 / 10$ a & $06 / 12$ a & 09/01 a & \\
\hline & $01 / 06 / 00$ & $12 / 07 / 00$ & 05/09/00 & $26 / 10 / 00$ & $20 / 12 / 00$ & $18 / 01 / 01$ & \\
\hline & \multicolumn{7}{|c|}{ Altura do dossel forrageiro $(\mathrm{cm})$ - Antes da entrada dos ovinos } \\
\hline MFI & $43^{\mathrm{a}}$ & $42^{\mathrm{a}}$ & $49^{\mathrm{a}}$ & $58^{\mathrm{a}}$ & $95^{\mathrm{a}}$ & $59^{\mathrm{a}}$ & $58^{\mathrm{a}}$ \\
\hline \multirow[t]{2}{*}{$\mathrm{AE}$} & $39^{\mathrm{a}}$ & $38^{\mathrm{a}}$ & $41^{\mathrm{b}}$ & $59^{\mathrm{a}}$ & $88^{\mathrm{a}}$ & $52^{\mathrm{a}}$ & $53^{\mathrm{b}}$ \\
\hline & \multicolumn{7}{|c|}{ Altura do dossel forrageiro (cm)-Após a saída dos ovinos } \\
\hline MFI & $17^{\mathrm{a}}$ & $11^{\mathrm{a}}$ & $9^{\mathrm{a}}$ & $21^{\mathrm{a}}$ & $29^{\mathrm{a}}$ & $26^{\mathrm{a}}$ & $19^{\mathrm{a}}$ \\
\hline $\mathrm{AE}$ & $18^{\mathrm{a}}$ & $11^{\mathrm{a}}$ & $7^{\mathrm{a}}$ & $24^{a}$ & $27^{\mathrm{a}}$ & $25^{\mathrm{a}}$ & $19^{a}$ \\
\hline
\end{tabular}

Tabela 6. Porcentagem de lâminas foliares do componente aruana antes da entrada dos ovinos em pastagens de capim-anua na exclusivo (AE) e capim-aruana sobresemeado com a mistura de espécies forrageiras de inverno (MFI) e dos componentes aveia preta e azevém na pastagem MFI em seis períodos de pastejo $(\mathrm{P})$ no primeiro ano do experimento

\begin{tabular}{|c|c|c|c|c|c|c|c|}
\hline \multirow{4}{*}{$\begin{array}{l}\text { Tipos de } \\
\text { Pastagem }\end{array}$} & \multicolumn{7}{|c|}{ Períodos de Pastejo } \\
\hline & $\mathrm{P} 1$ & $\mathrm{P} 2$ & P3 & P4 & P5 & P6 & Média * \\
\hline & $24 / 05$ a & $04 / 07 \mathrm{a}$ & $30 / 08 \mathrm{a}$ & $18 / 10 \mathrm{a}$ & $06 / 12 \mathrm{a}$ & 09/01 a & \\
\hline & $01 / 06 / 00$ & $12 / 07 / 00$ & 05/09/00 & $26 / 10 / 00$ & $20 / 12 / 00$ & $18 / 01 / 01$ & \\
\hline & \multicolumn{7}{|c|}{ Lâminas (\%) - aruana } \\
\hline MFI & $73,2^{\mathrm{a}}$ & $70,4^{\mathrm{a}}$ & $78,6^{\mathrm{a}}$ & $53,4^{\mathrm{a}}$ & $46,7^{\mathrm{a}}$ & $47,3^{\mathrm{a}}$ & $61,6^{\mathrm{a}}$ \\
\hline \multirow[t]{2}{*}{$\mathrm{AE}$} & $74,0^{\mathrm{a}}$ & $73,3^{\mathrm{a}}$ & $80,0^{\mathrm{a}}$ & $54,4^{\mathrm{a}}$ & $46,0^{\mathrm{a}}$ & $51,3^{\mathrm{a}}$ & $63,2^{\mathrm{a}}$ \\
\hline & \multicolumn{7}{|c|}{ Lâminas (\%)-aveia preta } \\
\hline \multirow[t]{2}{*}{ MFI } & $65,5^{\mathrm{A}}$ & $41,3^{\mathrm{B}}$ & $19,8^{\mathrm{C}}$ & - & - & - & 42,2 \\
\hline & \multicolumn{7}{|c|}{ Lâminas (\%)- azevém } \\
\hline MFI & $79,6^{\mathrm{A}}$ & $79,1^{\mathrm{A}}$ & $51,2^{\mathrm{B}}$ & $15,7^{\mathrm{C}}$ & - & - & 57,6 \\
\hline
\end{tabular}


Moreira et al. (2002) também observaram que a relação lâmina foliar/colmo do componente Tifton-85 da pastagem dessa espécie forrageira que recebeu a introdução de diferentes misturas de espécies hibernais foi semelhante à relação lâmina foliar/colmo desse componente na pastagem exclusiva do capim-tifton- 85 .

Para o componente aveia preta, as porcentagens de lâminas foliares (Tabela 6) decresceram significativamente $(\mathrm{P}<0,10)$ do primeiro para o segundo período e deste para o terceiro período de pastejo, com as seguintes proporções: 65,5\%, 41,3\% e 19,8\%, respectivamente, sendo que no último período a aveia estava em florescimento. Moreira et al. (2001) e Seixas et al. (2001) também observaram diminuição na proporção de folhas, em decorrência do florescimento, em genótipos de aveia cultivados em Jaboticabal.

Já o azevém (Tabela 6) apresentou proporções semelhantes $(\mathrm{P}>0,10)$ de lâminas foliares no primeiro e segundo períodos, porém com porcentagens maiores que nos períodos posteriores. No terceiro período (final da estação de inverno), com a elongação das hastes, iniciou-se a queda da fração lâmina, diminuindo $(\mathrm{P}<0,10)$ até a fase reprodutiva no quarto período, que teve a menor proporção de lâminas em relação aos três períodos precedentes.

\subsubsection{Segundo Ano Experimental - Massa de forragem e dos componentes botânicos, acúmulo de forragem e taxa média diária de acúmulo de forragem, altura do dossel forrageiro e porcentagens de lâminas foliares}

A Tabela 7 apresenta os dados de massa de forragem e dos componentes botânicos (aruana, invasoras, material morto, aveia preta e azevém) no dossel forrageiro de pastagens de capim-aruana exclusivo e capim-aruana sobre-semeado com a mistura de aveia preta e azevém, em seis períodos de pastejo, no segundo ano do experimento.

Para a variável massa total de forragem não houve interação $(P=0,2608)$ entre períodos de pastejo e tipos de pastagem. Também não houve diferença significativa entre os dois tipos de pastagem $(P=0,6113)$ na média dos seis períodos, obtendo-se as 
seguintes quantidades: 3,46 e 3,34 $\mathrm{Mg} \mathrm{MS}^{-1} \mathrm{ha}^{-1}$ respectivamente para a pastagem de capim-aruana com a MFI e para a da pastagem de AE (Tabela 7).

Resultados diferentes foram encontrados por Lupatini et al. (1998a), em que as misturas de espécies forrageiras de inverno resultaram em aumento da produção e do período de utilização da pastagem.

Tabela 7. Massa de forragem e componentes botânicos no dossel forrageiro de pastagens de capim-aruana exclusivo (AE) e capim-aruana sobre-semeado com uma mistura de espécies forrageiras de inverno (MFI) antes da entrada dos ovinos em seis períodos de pastejo $(\mathrm{P})$ no segundo ano do experimento

\begin{tabular}{|c|c|c|c|c|c|c|c|}
\hline \multirow{4}{*}{$\begin{array}{l}\text { Tipos de } \\
\text { Pastagem }\end{array}$} & \multicolumn{7}{|c|}{ Períodos de Pastejo } \\
\hline & P1 & $\mathrm{P} 2$ & P3 & $\mathrm{P} 4$ & P5 & P6 & Média* \\
\hline & $27 / 07$ a & 06/09 a & $22 / 10 \mathrm{a}$ & $26 / 11$ a & $02 / 01 \mathrm{a}$ & 06/02 a & \\
\hline & $06 / 08 / 01$ & $16 / 09 / 01$ & $02 / 11 / 01$ & $11 / 12 / 01$ & $14 / 01 / 02$ & $22 / 02 / 02$ & \\
\hline \multicolumn{8}{|c|}{ Total $\left(M g M S h a^{-1}\right)$} \\
\hline MFI & $2,55^{\mathrm{a}}$ & $2,14^{\mathrm{a}}$ & $3,23^{\mathrm{a}}$ & $4,14^{\mathrm{a}}$ & $4,16^{\mathrm{a}}$ & $4,26^{\mathrm{a}}$ & $3,46^{\mathrm{a}}$ \\
\hline $\mathrm{AE}$ & $2,03^{\mathrm{a}}$ & $2,26^{\mathrm{a}}$ & $3,44^{\mathrm{a}}$ & $3,36^{\mathrm{a}}$ & $5,09^{\mathrm{a}}$ & $3,99^{\mathrm{a}}$ & $3,34^{\mathrm{a}}$ \\
\hline \multicolumn{8}{|c|}{ Aruana $\left(M g M S h a^{-1}\right)$} \\
\hline MFI & $1,56^{\mathrm{a}}$ & $1,46^{\mathrm{a}}$ & $2,48^{\mathrm{a}}$ & $3,30^{\mathrm{a}}$ & $3,26^{\mathrm{a}}$ & $3,10^{\mathrm{a}}$ & $2,53^{\mathrm{a}}$ \\
\hline $\mathrm{AE}$ & $1.46^{\mathrm{a}}$ & $1,84^{\mathrm{a}}$ & $2,88^{\mathrm{a}}$ & $2,83^{\mathrm{a}}$ & $4,06^{\mathrm{a}}$ & $2,73^{\mathrm{a}}$ & $2,64^{\mathrm{a}}$ \\
\hline \multicolumn{8}{|c|}{ Invasoras (Mg MS ha-1) } \\
\hline MFI & $0,25^{\mathrm{a}}$ & $0,08^{\mathrm{a}}$ & $0,36^{\mathrm{a}}$ & $0,39^{\mathrm{a}}$ & $0,26^{\mathrm{a}}$ & $0,38^{\mathrm{a}}$ & $0,25^{\mathrm{a}}$ \\
\hline $\mathrm{AE}$ & $0,21^{\mathrm{a}}$ & $0,10^{\mathrm{a}}$ & $0,23^{\mathrm{a}}$ & $0,20^{\mathrm{a}}$ & $0,28^{\mathrm{a}}$ & $0,47^{\mathrm{a}}$ & $0,29^{\mathrm{a}}$ \\
\hline \multicolumn{8}{|c|}{ Material morto (Mg MS $\left.h a^{-1}\right)$} \\
\hline MFI & $0,37^{\mathrm{a}}$ & $0,46^{\mathrm{a}}$ & $0,26^{\mathrm{a}}$ & $0,43^{\mathrm{a}}$ & $0,71^{\mathrm{a}}$ & $0,78^{\mathrm{a}}$ & $0,50^{\mathrm{a}}$ \\
\hline $\mathrm{AE}$ & $0,36^{\mathrm{a}}$ & $0,33^{\mathrm{a}}$ & $0,38^{\mathrm{a}}$ & $0,33^{\mathrm{a}}$ & $0,74^{\mathrm{a}}$ & $0,79^{\mathrm{a}}$ & $0,49^{\mathrm{a}}$ \\
\hline \multicolumn{8}{|c|}{ Aveia preta $\left(M g M S h a^{-1}\right)$} \\
\hline MFI & $0,34^{\mathrm{A}}$ & $0,13^{\mathrm{B}}$ & - & - & - & - & 0,24 \\
\hline \multicolumn{8}{|c|}{ Azevém (Mg MS ha-1) } \\
\hline MFI & $0,05^{\mathrm{B}}$ & $0,06^{\mathrm{B}}$ & $0,17^{\mathrm{A}}$ & - & - & - & 0,09 \\
\hline
\end{tabular}


Não houve diferença entre tipos de pastagem quanto ao componente capimaruana (Tabela 7), tanto na média dos seis períodos de pastejo $(P=0,6035)$, quanto em cada período de pastejo. Também não houve interação tipo de pastagem x períodos de pastejo $(P=0,3405)$. Em termos proporcionais e na média dos seis períodos de pastejo, o componente aruana contribuiu com $73,1 \%$ e $78,7 \%$ do total de forragem pré-pastejo nas pastagens com MFI e nas com AE, respectivamente.

Não existiu diferença entre os dois tipos de pastagem na média dos seis períodos de pastejo, para os componentes botânicos plantas invasoras $(P=0,7410)$ e material morto $(P=0,7577)$, que representaram 7,2 e $8,6 \%$ para o componente invasoras e $14,7 \%$ e $14,4 \%$ para o material morto, respectivamente na pastagem de aruana com sobresemeadura e testemunha (Tabela 7).

Ao contrário dos resultados deste experimento, Roso et al. (1999) obtiveram grande participação de material morto e invasoras em pastagens com a mistura de triticale, aveia preta e azevém devido à senescência das plantas de triticale e aveia que, ao se aproximarem da fase reprodutiva, emitiram inflorescências e foram pastejadas, tendo sido eliminados, portanto, os pontos de crescimento.

A aveia preta esteve presente no primeiro (P1: 27/07 a 06/08/01) e segundo (P2: 06/09 a 16/09/01) períodos de pastejo, com maior massa de forragem $(\mathrm{P}<0,10)$ no primeiro, não mais estando presente a partir do terceiro período. Já o azevém apresentou baixa ocorrência no primeiro e segundo períodos de pastejo, aumentou significativamente sua participação $(\mathrm{P}<0,10)$ no terceiro $(\mathrm{P} 3$ : 22/10 a 02/11/01), desaparecendo a partir do quarto período de pastejo (Tabela 7). O comportamento tanto da aveia quanto do azevém, observado no presente trabalho, segundo o qual a aveia apresentou rápido crescimento inicial com diminuição da produção no período seguinte, e do azevém, apresentando desenvolvimento lento e aumento de produção de forragem com as temperaturas mais elevadas de primavera (terceiro período), concorda com o já observado por Floss (1988) e Moraes \& Lustosa (1999) na região Sul do País.

Todavia, a baixa contribuição das espécies forrageiras de inverno na pastagem do capim-aruana, no segundo ano do experimento, esteve mais relacionada com a ineficiência do sistema de irrigação durante o período critico do ano (junho-agosto), 
gerada por limitação no fornecimento de água (baixo nível de água da represa de captação fornecendo, assim, uma quantidade de água inferior à desejada), do que com a data tardia da semeadura. Enquanto o problema do déficit hídrico não ocorreu, a contribuição da aveia-preta e do azevém na pastagem de capim-aruana sobre-semeado permaneceu adequada para as condições climáticas do período.

Para a variável massa de forragem remanescente após a saída dos animais das pastagens (Tabela 8) houve interação $(P=0,0982)$ entre período de pastejo e tipo de pastagem. Também houve diferença significativa entre os dois tipos de pastagem $(P=0,0345)$, na média dos seis períodos de pastejo, com os maiores valores de massa de forragem residual na pastagem sobre-semeada em relação à pastagem testemunha $(2,09$ e 1,84 Mg MS ha ${ }^{-1}$, respectivamente).

Tabela 8. Massa de forragem remanescente após a saída dos ovinos nas pastagens de capim-aruana exclusivo (AE) e capim-aruana sobre-semeado com uma mistura de espécies forrageiras de inverno (MFI) em seis períodos de pastejo (P) no segundo ano do experimento

\begin{tabular}{|c|c|c|c|c|c|c|c|}
\hline \multirow{3}{*}{$\begin{array}{l}\text { Tipos de } \\
\text { Pastagem }\end{array}$} & \multicolumn{7}{|c|}{ Períodos de Pastejo } \\
\hline & P1 & P2 & P3 & P4 & P5 & P6 & Média* \\
\hline & $\begin{array}{c}27 / 07 \text { a } \\
06 / 08 / 01\end{array}$ & $\begin{array}{c}06 / 09 \text { a } \\
16 / 09 / 01\end{array}$ & $\begin{array}{c}22 / 10 \mathrm{a} \\
02 / 11 / 01\end{array}$ & $\begin{array}{c}26 / 11 \mathrm{a} \\
11 / 12 / 01\end{array}$ & $\begin{array}{c}02 / 01 \mathrm{a} \\
14 / 01 / 02\end{array}$ & $\begin{array}{c}06 / 02 \mathrm{a} \\
22 / 02 / 02\end{array}$ & \\
\hline \multicolumn{8}{|c|}{ Forragem remanescente - $\left(M g M S h a^{-1}\right)$} \\
\hline MFI & $1,63^{\mathrm{a}}$ & $1,42^{\mathrm{a}}$ & $1,66^{\mathrm{a}}$ & $2,49^{\mathrm{a}}$ & $2,38^{\mathrm{a}}$ & $2,96^{\mathrm{a}}$ & $2,09^{\mathrm{a}}$ \\
\hline $\mathrm{AE}$ & $1,58^{\mathrm{a}}$ & $1,03^{\mathrm{b}}$ & $1,38^{\mathrm{a}}$ & $2,38^{\mathrm{a}}$ & $2,24^{\mathrm{a}}$ & $2,46^{\mathrm{b}}$ & $1,84^{\mathrm{b}}$ \\
\hline
\end{tabular}

Na Tabela 8, no segundo (P2: 06/09 a 16/09/01) e sexto (P6: 06/02 a 22/02/02) períodos de pastejo, a maior $(\mathrm{P}<0,10)$ massa de forragem pós-pastejo foi da pastagem contendo a MFI em relação à pastagem exclusiva. Nos demais períodos, os valores de massa de forragem residual foram semelhantes $(\mathrm{P}>0,10)$ entre os dois tipos de pastagem.

$\mathrm{O}$ acúmulo de forragem, em cada período de rebrotação e o total acumulado ao longo desses períodos no segundo ano experimental estão mostrados na Tabela 9. Não 
houve diferença entre tipos de pastagem quanto ao acúmulo de forragem, tanto na média dos seis períodos de rebrotação $(P=0,7591)$, quanto no total dos seis períodos de rebrotação das pastagens $(P=0,7583)$. Também não houve interação tipo de pastagem $\mathrm{x}$ período de rebrotação $(P=0,7903)$. Esses resultados discordam com os obtidos por Roso et al. (1999).

Tabela 9. Acúmulo e taxa média diária de acúmulo de forragem em pastagens de capimaruana exclusivo (AE) e capim-aruana sobre-semeado com uma mistura de forrageiras de inverno (MFI) em seis períodos de rebrotação (R) no segundo ano do experimento

\begin{tabular}{|c|c|c|c|c|c|c|c|c|}
\hline \multirow[b]{2}{*}{$\begin{array}{l}\text { Tipos de } \\
\text { Pastagem }\end{array}$} & \multicolumn{8}{|c|}{ Períodos de rebrotação } \\
\hline & $\begin{array}{c}\text { R1:50 dias } \\
07 / 06 \mathrm{a} \\
27 / 07 / 01\end{array}$ & $\begin{array}{c}\text { R2:39 dias } \\
29 / 07 \text { a } \\
06 / 09 / 01\end{array}$ & $\begin{array}{c}\text { R3:43 dias } \\
\text { 09/09 a } \\
\text { 22/10/01 }\end{array}$ & $\begin{array}{c}\mathrm{R} 4: 32 \text { dias } \\
25 / 10 \mathrm{a} \\
26 / 11 / 01\end{array}$ & $\begin{array}{c}\text { R5:34 dias } \\
29 / 11 \text { a } \\
02 / 01 / 01\end{array}$ & $\begin{array}{c}\text { R6:30 dias } \\
07 / 01 \mathrm{a} \\
06 / 02 / 02\end{array}$ & Média* & Total \\
\hline \multicolumn{9}{|c|}{ Acúmulo de forragem (Mg MS ha $\left.{ }^{-1}\right)$} \\
\hline MFI & $2,55^{\mathrm{a}}$ & $0,64^{\mathrm{a}}$ & $1,17^{\mathrm{a}}$ & $2,68^{\mathrm{a}}$ & $2,30^{\mathrm{a}}$ & $1,88^{\mathrm{a}}$ & $1,87^{\mathrm{a}}$ & $11,22^{\mathrm{a}}$ \\
\hline $\mathrm{AE}$ & $2,03^{\mathrm{a}}$ & $0,55^{\mathrm{a}}$ & $1,63^{\mathrm{a}}$ & $1,93^{\mathrm{a}}$ & $2,71^{\mathrm{a}}$ & $1,94^{\mathrm{a}}$ & $1,80^{\mathrm{a}}$ & $10,79^{\mathrm{a}}$ \\
\hline Média & $2,29^{\mathrm{A}}$ & $0,60^{\mathrm{C}}$ & $1,40^{\mathrm{B}}$ & $2,30^{\mathrm{A}}$ & $2,51^{\mathrm{A}}$ & $1,91^{\mathrm{AB}}$ & - & - \\
\hline EPM & 0,2316 & 0,1552 & 0,3117 & 0,3755 & 0,5166 & 0,3256 & - & - \\
\hline \multicolumn{9}{|c|}{ Taxa média de acúmulo de forragem ( $\mathrm{kg} \mathrm{MS} \mathrm{ha-1}$ dia $\left.^{-1}\right)$} \\
\hline MFI & $47,17^{\mathrm{a}}$ & $16,72^{\mathrm{a}}$ & $27,40^{\mathrm{a}}$ & $85,87^{\mathrm{a}}$ & $72,90^{\mathrm{a}}$ & $52,64^{\mathrm{a}}$ & $50,45^{\mathrm{a}}$ & - \\
\hline $\mathrm{AE}$ & $37,18^{\mathrm{a}}$ & $14,49^{\mathrm{a}}$ & $38,27^{\mathrm{a}}$ & $61,84^{\mathrm{a}}$ & $84,82^{\mathrm{a}}$ & $55,08^{\mathrm{a}}$ & $48,62^{\mathrm{a}}$ & - \\
\hline Média & $42,18^{\mathrm{BC}}$ & $15,61^{\mathrm{D}}$ & $32,84^{\mathrm{C}}$ & $73,86^{\mathrm{A}}$ & $78,86^{\mathrm{A}}$ & $53,86^{\mathrm{AB}}$ & - & - \\
\hline EPM & 4,5056 & 4,3053 & 6,8985 & 13,0228 & 16,1994 & 10,0807 & - & - \\
\hline
\end{tabular}

As taxas média diária de acúmulo de forragem (Tabela 9) foram semelhantes $(\mathrm{P}>0,10)$ entre as duas pastagens estudadas, em todos os períodos de rebrotação e na média destes períodos. Entretanto, na média dos dois tipos de pastagem houve diferença $(\mathrm{P}<0,10)$ entre os períodos, sendo maiores nos $\mathrm{R} 4$ e R5, intermediários nos R6 e R1 e menores nos R2 e R3 devido às condições de precipitação pluviométricas e temperatura como era de se esperar, já que houve problemas de limitação de irrigação como á foi mencionado. 
A altura do dossel forrageiro (Tabela 10) antes da entrada dos animais na pastagem sobre-semeada com a MFI apresentou-se maior $(P=0,0985)$ em relação à pastagem de aruana exclusivo, na média dos seis períodos de pastejo (MFI= $62 \mathrm{~cm} \mathrm{e}$ $\mathrm{AE}=57 \mathrm{~cm}$ ). Somente no primeiro período de pastejo (julho/agosto) houve diferença $(P=0,0002)$ entre os dois tipos de pastagem com $51 \mathrm{~cm}$ em MFI e $33 \mathrm{~cm}$ em AE, respectivamente. A altura do dossel forrageiro após a saída dos animais (Tabela 10), para os dois tipos de pastagem, foi semelhante $(P=0,1054)$ nos seis períodos de pastejo e na sua média.

Tabela 10. Altura do dossel forrageiro antes da entrada e após a saída dos ovinos nas pastagens de capim-aruana exclusivo (AE) e capim-aruana sobre-semeado com uma mistura de espécies forrageiras de inverno (MFI) em seis períodos de pastejo $(\mathrm{P})$ no segundo ano do experimento

\begin{tabular}{|c|c|c|c|c|c|c|c|}
\hline \multirow{4}{*}{$\begin{array}{c}\text { Tipos } \\
\text { de Pastagem }\end{array}$} & \multicolumn{7}{|c|}{ Períodos de pastejo } \\
\hline & P1 & $\mathrm{P} 2$ & P3 & $\mathrm{P} 4$ & P5 & P6 & Média* \\
\hline & $27 / 07 \mathrm{a}$ & $06 / 09$ a & $22 / 10 \mathrm{a}$ & $26 / 11 \mathrm{a}$ & $02 / 01 \mathrm{a}$ & $06 / 02$ a & \\
\hline & 06/08/01 & $16 / 09 / 01$ & $02 / 11 / 01$ & $11 / 12 / 01$ & $14 / 01 / 02$ & $22 / 02 / 02$ & \\
\hline & \multicolumn{7}{|c|}{ Altura do dossel forrageiro $(\mathrm{cm})$ - Antes da entrada dos animais } \\
\hline MFI & $51^{\mathrm{a}}$ & $59^{\mathrm{a}}$ & $60^{\mathrm{a}}$ & $67^{\mathrm{a}}$ & $71^{\mathrm{a}}$ & $59^{\mathrm{a}}$ & $62^{\mathrm{a}}$ \\
\hline \multirow[t]{2}{*}{$\mathrm{AE}$} & $33^{\mathrm{b}}$ & $60^{\mathrm{a}}$ & $54^{\mathrm{a}}$ & $63^{\mathrm{a}}$ & $70^{\mathrm{a}}$ & $60^{\mathrm{a}}$ & $57^{\mathrm{b}}$ \\
\hline & \multicolumn{7}{|c|}{ Altura do dossel forrageiro(cm)-Após a saída dos animais } \\
\hline MFI & $14^{\mathrm{a}}$ & $33^{\mathrm{a}}$ & $19^{\mathrm{a}}$ & $32^{\mathrm{a}}$ & $41^{\mathrm{a}}$ & $31^{\mathrm{a}}$ & $28^{\mathrm{a}}$ \\
\hline $\mathrm{AE}$ & $13^{\mathrm{a}}$ & $29^{a}$ & $13^{\mathrm{a}}$ & $30^{\mathrm{a}}$ & $34^{\mathrm{a}}$ & $28^{\mathrm{a}}$ & $25^{\mathrm{a}}$ \\
\hline
\end{tabular}

Para porcentagem de lâminas foliares do componente aruana (Tabela 11) não houve interação $(P=0,7344)$ entre tipos de pastagem e períodos de pastejo e nem houve diferença significativa $(P=0,5635)$ entre as duas pastagens, para a média dos seis períodos de pastejo, coincidindo com os resultados de Moreira et al. (2002), em estudo com o capim-tifton- 85 .

Para o componente aveia preta (Tabela 11), que teve presença somente nos dois primeiros períodos de pastejo, as proporções de lâminas decresceram $(\mathrm{P}<0,10)$ de 
73,4 \% no primeiro (P1: 27/07 a 06/08/01) para 34,5 \% no segundo período de pastejo (P2: 06/09 a 16/09/01), provavelmente por já estar em estádio de florescimento neste último período.

Tabela 11. Porcentagem de lâminas foliares do componente aruana antes da entrada dos ovinos em pastagens de capim-aruana exclusivo (AE) e capim-aruana sobresemeado com a mistura de espécies forrageiras de inverno (MFI) e dos componentes aveia preta e azevém na pastagem MFI em seis períodos de pastejo $(\mathrm{P})$ no segundo ano do experimento

\begin{tabular}{|c|c|c|c|c|c|c|c|}
\hline \multirow{4}{*}{$\begin{array}{l}\text { Tipos de } \\
\text { Pastagem }\end{array}$} & \multicolumn{7}{|c|}{ Períodos de Pastejo } \\
\hline & P1 & P2 & P3 & P4 & P5 & P6 & Média* \\
\hline & $27 / 07 \mathrm{a}$ & $06 / 09$ a & $22 / 10 \mathrm{a}$ & $26 / 11 \mathrm{a}$ & 02/01 a & 06/02 a & \\
\hline & 06/08/01 & 16/09/01 & $02 / 11 / 01$ & $11 / 12 / 01$ & $14 / 01 / 02$ & $22 / 02 / 02$ & \\
\hline & \multicolumn{7}{|c|}{ Lâminas (\%)- aruana } \\
\hline MFI & $81,3^{\mathrm{a}}$ & $66,3^{\mathrm{a}}$ & $59,3^{\mathrm{a}}$ & $55,0^{\mathrm{a}}$ & $37,7^{\mathrm{a}}$ & $42,5^{\mathrm{a}}$ & $57,0^{\mathrm{a}}$ \\
\hline \multirow[t]{2}{*}{$\mathrm{AE}$} & $82,1^{\mathrm{a}}$ & $73,5^{\mathrm{a}}$ & $64,6^{\mathrm{a}}$ & $57,4^{\mathrm{a}}$ & $37,8^{\mathrm{a}}$ & $43,5^{\mathrm{a}}$ & $59,8^{\mathrm{a}}$ \\
\hline & \multicolumn{7}{|c|}{ Lâminas (\%)-aveia preta } \\
\hline \multirow[t]{2}{*}{ MFI } & $73,4^{\mathrm{A}}$ & $34,5^{\mathrm{B}}$ & - & - & - & - & 56,1 \\
\hline & \multicolumn{7}{|c|}{ Lâminas (\%)- azevém } \\
\hline MFI & $89,4^{\mathrm{A}}$ & $69,0^{\mathrm{B}}$ & $16,3^{\mathrm{C}}$ & - & - & - & 58,2 \\
\hline
\end{tabular}

As porcentagens de lâminas foliares do azevém (Tabela 11) diminuíram $(\mathrm{P}<0,10)$ do primeiro $(89,4 \%)$ para o segundo $(69,0 \%)$ e deste para o terceiro período de pastejo $(16,3 \%)$. Períodos em que esta forrageira de inverno esteve presente. Essas observações concordam com a afirmação de Roso et al. (1999) de que ocorre uma redução acentuada da área foliar com o avanço do tempo em que o azevém se mostra presente na pastagem em que é sobre-semeado. 


\subsection{Conclusões}

Pastos de capim-aruana convenientemente adubados e irrigados que recebam sobre-semeadura com espécies forrageiras de inverno produzem mais forragem no período crítico em relação a pastos não sobre-semeados, nas condições do Estado de São Paulo. Mas pastos não sobre-semeados desse capim, que recebam os mesmos cuidados de adubação e irrigação no outono/inverno, apresentam boa produção de forragem.

Pastos de capim-aruana sobre-semeados permitiram maior presença de plantas invasoras que pastos exclusivos desse capim.

Apesar da presença das espécies forrageiras de inverno ter sido pouco expressiva, a aveia preta teve contribuição mais precoce que o azevém, estando a primeira mais presente em julho e o azevém em setembro. 


\section{COMPOSIÇÃO QUÍMICA E DIGESTIBILIDADE DA MASSA DE FORRAGEM EM PASTAGEM IRRIGADA DE CAPIM-ARUANA EXCLUSIVO OU SOBRE-SEMEADO COM UMA MISTURA DE AVEIA PRETA E AZEVÉM}

\section{Resumo}

No Instituto de Zootecnia, Nova Odessa, SP, em uma pastagem de capim-aruana (Panicum maximum Jacq. cv. Aruana) utilizada com ovinos em sistema intensivo de produção (irrigação, adubação e lotação rotacionada), foi sobre-semeada uma mistura de duas espécies forrageiras de inverno: aveia preta (Avena strigosa Schreb cv. Comum) e azevém anual (Lolium multiflorum Lam. cv. Comum) com o objetivo de melhorar o valor nutritivo da forragem no período crítico do ano. Durante seis períodos de pastejo, ocorridos em cada ano (primeiro ano: 14/04/00 a 18/01/01 e segundo ano: 07/06/01 a 22/02/02), foram avaliadas a composição química e digestibilidade da forragem, antes da entrada dos animais (pré pastejo) nas pastagens. O delineamento experimental foi de blocos completos casualizados (quatro), com duas repetições dentro do bloco e dois tratamentos: 1) capim-aruana exclusivo e 2) capim-aruana sobre-semeado. Para as amostras do total da forragem pré-pastejo e para as dos seus componentes forrageiros (aruana, aveia preta e azevém) avaliaram-se a proteína bruta, FDN, FDA, lignina e digestibilidade "in vitro" da matéria seca. No primeiro ano, a PB da forragem de capimaruana exclusivo foi maior em relação ao sobre-semeado no terceiro período de pastejo e semelhante nos demais. A PB dos componentes aveia e azevém, no terceiro período, foi menor em relação aos do primeiro e segundo. FDN, FDA e lignina da forragem no 
tratamento exclusivo foram mais elevados em relação aos do tratamento sobre-semeado, na média dos seis períodos. Aveia e azevém apresentaram FDN mais baixos nos períodos iniciais de crescimento, com aumento no último. A digestibilidade da forragem foi semelhante nos dois tratamentos, em todos os períodos de avaliação. No segundo ano, o teor de PB da massa total de forragem da pastagem de capim-aruana exclusivo foi maior que o da pastagem sobre-semeada, no quarto período mas semelhante nos demais e na média dos seis períodos. A PB da aveia e do azevém decresceram ao longo dos períodos de pastejo. FDN, FDA, lignina e DIVMS da massa total de forragem foram semelhantes entre as duas pastagens na média e ao longo dos seis períodos, exceto para FDN no segundo período. Aveia e azevém apresentaram maiores teores de FDN, FDA e lignina no último período de pastejo. A DIVMS do azevém manteve-se constante nos dois primeiros períodos de pastejo diminuindo no último. Pastos com capim-aruana, que recebam adubação nitrogenada, irrigação e manejo adequados, apresentam composição química e digestibilidade semelhantes às de pastos do capim sobre-semeados com aveia preta e azevém.

\section{Summary}

At Instituto de Zootecnia, Nova Odessa, SP, in a pasture aruanagrass Panicum maximum Jacq. cv. Aruana) grazed by sheep in an intensive production system (irrigation, fertilization and rotational stocking) it was introduced a mixture of two winter forages: black oat (Avena strigosa Schreb. cv. Common) and italian ryegrass (Lolium multiflorum Lam. cv. Common) with the objective of increasing the forage nutritive value supply during the dry winter period. The mixture was broadcast sown over the grass on 04-14-00 and 06-07-01 in two years of experiment. From 04-14-00 to 01-18-01 and 06-07-01 to 02-22-02 it was evaluated, in six annual grazing periods, the chemical composition and digestibility of the forage. The experimental design was a completely randomized blocks (four) with two replications within the block. The treatments were: 1) grass alone and 2) grass oversown with black oat and italian ryegrass. It was evaluated in the forage on offer and in its botanical components, crude 
protein $(\mathrm{CP})$, neutral detergent fiber $(\mathrm{NDF})$, acid detergent fiber (ADF), lignin and in vitro dry matter digestibility (IVDMD), in the six grazing periods of each year. In the first year, the $\mathrm{CP}$ in the forage from the grass pasture alone was greater than the one of the oversown grass pasture in the third period, and similar in the others. Oat and ryegrass $\mathrm{CP}$ was lower in the third period than the ones of the first and second ones. NDF, ADF and lignin in the forage from the grass pasture alone were greater than the ones of the oversown pasture. Oat and ryegrass NDF was lowest in the initial growth periods, increasing in the final. Forage IVDMD from the two treatments were similar in all evaluation periods. In the second year the $\mathrm{CP}$ in the forage from the grass pasture alone was greater than the one of the oversown pasture in the fourth period, and similar in the others. Oat and ryegrass $\mathrm{CP}$ decreased along the grazing periods. NDF, ADF, lignin and IVDMD of the forage from the two treatments were similar in all evaluation periods. Oat and ryegrass $\mathrm{NDF}, \mathrm{ADF}$ and lignin were greater in the last grazing period. Ryegrass IVDMD from the first two periods were similar and decreased in the final. Aruanagrass pastures fertilized, irrigated and managed adequately present chemical composition and digestibility similar to aruanagrass pastures oversown with black oat and ryegrass.

\subsection{Introdução}

A produção animal em pastagem acompanha os ciclos de crescimento das plantas forrageiras, os quais estão relacionados com as chuvas e a temperatura. Entretanto, independentemente do método de pastejo empregado, os objetivos procurados visam sempre obter, economicamente, o máximo de produção de forragem de boa qualidade, com boa distribuição durante o ano, e que as pastagens se mantenham produtivas com a espécie ou com a mistura de espécies desejadas, em equilíbrio, por muitos anos.

As pastagens, pela sua natureza, são sensíveis a muitos fatores, tais como fertilidade do solo, clima, espécies forrageiras utilizadas, idade da planta, etc, que afetam a composição química da forragem produzida.

A composição química da forragem é um dos parâmetros utilizados para medir seu valor nutritivo. O baixo valor nutritivo das espécies forrageiras tropicais é 
frequentemente mencionado na literatura e está associado ao reduzido teor de proteína bruta e minerais e ao alto conteúdo de fibras (lignina, celulose, hemiceluloses protegidas, cutícula e sílica). Consequentemente, decréscimos na digestibilidade são esperados (Blaser, 1964; Van Soest, 1982).

Plantas jovens, imaturas, normalmente têm alta digestibilidade e adequada composição química. O consumo esperado é alto, se houver quantidade suficiente de forragem para propiciar ao animal oportunidade de seleção. À medida que a planta amadurece o valor nutricional decresce devido à diluição dos nutrientes e ao aumento nos componentes fibrosos.

Quando a concentração de nutrientes cai abaixo da concentração exigida pelo animal e ocorre a deficiência de um ou mais nutrientes, há efeitos adversos sobre o consumo de forragem, disponibilidade de nutrientes e desempenho animal. Os efeitos são freqüentemente estacionais e variam com o período em que as pastagens estão verdes e em crescimento, seguido por períodos de senescência, quando a disponibilidade de forragem é baixa (Wilkins, 1969; Vilela et al., 1978).

A prática da introdução de espécies forrageiras de ciclo hibernal em pastagens tropicais resulta numa melhor distribuição da forragem ao longo do ano e num aumento na proteína bruta e digestibilidade da forragem durante o período crítico do ano, obtendo-se um melhor desempenho animal (Reis, et al., 1993; Reis et al., 2001).

Entre as gramíneas tropicais, os cultivares de Panicum maximum normalmente apresentam qualidade de média a boa. Mas, para a produção animal, é importante levar em conta, além da composição da planta inteira, a das frações colmo e folhas, especialmente destas últimas, que são a porção mais consumida (Euclides, et al., 1996).

O capim-aruana tem se destacado por apresentar uma melhor distribuição anual de produção (Cecato et al., 1994; Ghisi et al., 1989) associado a um razoável valor nutritivo (Ghisi et al., 1989) durante o período crítico no ano.

As razões do bom desempenho animal em pastagens contendo a mistura de espécies forrageiras de inverno estão na qualidade bromatológica dessas plantas forrageiras que varia conforme o estádio do desenvolvimento das mesmas (Floss, 1988). 
A qualidade das espécies forrageiras de ciclo hibernal depende, dentre outros fatores, do manejo ao qual são submetidas na fase de produção, como irrigação, fertilização, altura, frequência e condições de pastejo (Alvim \& Cóser, 2000). Cecato et al. (1998) encontraram elevados teores de proteína bruta (17 a $23 \%$ ) e baixos teores de fibra em detergente ácido (27 a 34 \%) para a aveia preta quando manejada adequadamente.

Maia et al. (1998) acharam respostas diferenciadas de valor nutritivo da pastagem contendo a mistura de aveia preta e azevém anual, em função do ciclo de crescimento. O teor máximo de proteína bruta para o período de crescimento referente aos 116 dias após semeadura foi de 17\%, caindo para 3,2 \% aos 223 dias. A digestibilidade "in vitro" da matéria seca dessa mistura variou de 77 a $44 \%$ para os respectivos períodos. No intervalo entre 55 e 194 dias após a semeadura, a forragem proveniente dessa mistura apresentou alto valor nutritivo e viabilidade para a exploração pecuária.

Restle et al. (2000) semearam uma mistura de aveia preta e azevém sobre a palhada do milheto (Pennisetum americanum (L) Leeke) e obtiveram 22,4\% de PB e $57,4 \%$ de DIVMO na média dos períodos de pastejo de junho a início de novembro, no Sul do País.

Este trabalho teve como objetivo avaliar a composição química e a digestibilidade da forragem de uma pastagem de Panicum maximum Jacq. cv. Aruana, irrigada, adubada e sobre-semeada com uma mistura de duas espécies de forrageiras de inverno, manejada em lotação rotacionada com ovinos, durante seis períodos de pastejo, visando melhorar o valor nutritivo da forragem no período crítico (outono/inverno/início de primavera), nas condições do Estado de São Paulo.

\subsection{Material e Métodos}

O experimento foi conduzido na unidade de ovinos e laboratórios do Instituto de Zootecnia, Nova Odessa/SP. Aproveitou-se, para a instalação do experimento, um piquete (com aproximadamente $3000 \mathrm{~m}^{2}$ ) em uma área experimental situada num solo 
classificado como Argissolo Vermelho-Amarelo (EMBRAPA, 1999), constituída por 5 piquetes estabelecidos em 1991 com capim-aruana (Panicum maximum Jacq. cv. Aruana). Os dados climáticos (chuvas e temperaturas) referentes aos anos de execução do presente estudo, são mostrados na Figura 1.

Foram avaliadas a composição química e a digestibilidade da massa de forragem antes da entrada dos animais na pastagem composta da mistura de duas espécies forrageiras de inverno: aveia preta (Avena strigosa Schreb cv. Comum) e azevém (Lolium multiflorum Lam. cv. Comum) introduzidas em uma pastagem de capim-aruana irrigada, adubada e pastejada em lotação rotacionada com ovinos.

O delineamento experimental foi o de blocos completos casualizados, em número de quatro, com duas repetições por bloco. Os dois tratamentos testados foram: 1) capimaruana exclusivo, como testemunha e 2) capim-aruana sobre-semeado com uma mistura de duas espécies forrageiras de inverno (aveia preta e azevém), perfazendo um total de 16 parcelas experimentais de $100 \mathrm{~m}^{2}$ cada.

Para a introdução da mistura das duas forrageiras de inverno foi feito o rebaixamento prévio de todas as parcelas experimentais com pastejo (ovinos), obtendose uma altura do dossel em torno de $5 \mathrm{~cm}$. A sobre-semeadura das duas espécies forrageiras de inverno, à lanço nas parcelas correspondentes a este tratamento, ocorreu em 14 de abril/2000, no primeiro ano de experimento e em 07 de junho/2001, no segundo ano, misturando-se as sementes $\left(65 \mathrm{~kg} \mathrm{ha}^{-1}\right.$ de aveia preta, $30 \mathrm{~kg} \mathrm{ha}^{-1}$ de azevém) com os adubos (40 kg ha- ${ }^{-1}$ de $\mathrm{P}_{2} \mathrm{O}_{5}, 42 \mathrm{~kg} \mathrm{ha}^{-1}$ de $\mathrm{K}_{2} \mathrm{O}$ e $30 \mathrm{~kg} \mathrm{ha}^{-1}$ de FTE BR16).

Em novembro/2000, foi feita uma adubação nitrogenada (50 $\mathrm{kg} \mathrm{ha}^{-1}$ de $\left.\mathrm{N}\right) \mathrm{e}$ potássica $\left(50 \mathrm{~kg} \mathrm{ha}^{-1}\right.$ de $\left.\mathrm{K}_{2} \mathrm{O}\right)$ nas parcelas experimentais. Em março/2001 foi feita a adubação nitrogenada do final das águas, aplicando-se $100 \mathrm{~kg}$ de $\mathrm{kg} \mathrm{ha}^{-1} \mathrm{e}$, em meados de outubro/2001, início das águas, aplicaram-se $50 \mathrm{~kg} \mathrm{ha}^{-1}$ de $\mathrm{N}$.

A área foi dividida em faixas, delimitadas por cerca elétrica no momento do pastejo, sendo que cada bloco era constituído por uma faixa, pastejada em sequência, por dois a três dias, pelo mesmo lote de ovinos, simultaneamente nas parcelas do capimaruana exclusivo (testemunha) e nas da mistura das espécies forrageiras de inverno 
introduzidas sobre o capim. No primeiro ano experimental (14/04/00 a 18/01/01) ocorreram seis períodos de pastejo (P): P1: 24/05 a 01/06/00, P2: 04/07 a 12/07/00, P3: 30/08 a 05/09/00, P4: 18/10 a 26/10/00, P5: 06/12 a 20/12/00 e P6: 09/01 a 18/01/01 precedidos por seis períodos de descanso, com aproximadamente 40, 39, 55, 47, 46 e 32 dias, respectivamente. No segundo ano experimental (07/06/01 a 22/02/02) também houve seis períodos de pastejo (P): P1: 27/07 a 06/08/01, P2: 06/09 a 16/09/01, P3: 22/10 a 02/11/01, P4: 26/11 a 11/12/01, P5: 02/01 a 14/01/02 e P6: 06/02 a 22/02/02 e seis períodos de descanso, em torno de 50, 39, 43, 32, 34 e 30 dias respectivamente.

As amostragens eram feitas em quatro pontos por parcela $\left(100 \mathrm{~m}^{2}\right)$, antes da entrada dos animais, através do lançamento ao acaso de um quadrado de $0,25 \mathrm{~m}^{2}$, perfazendo um total de $1 \mathrm{~m}^{2}$. O corte era rente ao solo, com tesoura de poda. A forragem proveniente desta amostra foi pesada, e da mesma foram retiradas $200 \mathrm{~g}$ para a obtenção da sub-amostra do total de forragem pré-pastejo e, o restante, separado nos componentes botânicos capim-aruana, plantas invasoras, material morto, aveia preta e azevém que foram novamente pesados, amostrados e secados em estufa de circulação forçada de ar $\left(65^{\circ} \mathrm{C}\right)$, até peso constante.

Tanto nas amostras da massa total de forragem, quanto nas dos componentes forrageiros (aruana, aveia preta e azevém), após passarem pelo processo de moagem em moinho tipo Willey com peneira de 40 mesh, foram determinadas: porcentagem de matéria seca $\left(105^{\circ} \mathrm{C}\right)$, proteína bruta $(\mathrm{PB})$, fibra insolúvel em detergente neutro (FDN), fibra insolúvel em detergente ácido (FDA), lignina e digestibilidade "in vitro" da matéria seca (DIVMS).

As determinações do teor de matéria seca a $105{ }^{\circ} \mathrm{C}$ foram feitas segundo Silva (1981). A PB foi estimada pela análise do nitrogênio total multiplicado pelo fator 6,25. A digestão utilizada para a obtenção do extrato na determinação do nitrogênio total foi a sulfúrica e a destilação foi conduzida em aparelho semi-micro Kjeldahl, titulando-se posteriormente com ácido sulfúrico (Association of Official Analytical ChemistsAOAC,1995). 
Para o constituinte fibra (FDN, FDA e lignina) as determinações foram realizadas pelo método de Goering \& Van Soest (1970) e a DIVMS pelo método proposto por Tilley \& Terry (1963).

Os dados foram analisados através dos procedimentos MIXED e medidas repetidas no tempo (Repeated Measures) (Littell et al., 1996), do programa SAS ${ }^{\circledR}$ (Statistical Analysis System), SAS Institute (1990), a fim de se determinar a estrutura de matriz de variância e covariância. O nível de significância adotado para a análise de variância foi de $10 \%$. Para os efeitos significativos, foram realizados testes de comparação de médias, através do procedimento LSMEANS, com um nível de significância de $10 \%$. As interações significativas foram desdobradas de acordo com os fatores envolvidos.

\subsection{Resultados e Discussão}

\subsubsection{Primeiro Ano Experimental - Composição química e digestibilidade da massa de forragem e dos componentes forrageiros}

Na Tabela 12 são apresentados os teores de proteína bruta da massa total de forragem e dos seus componentes forrageiros (aruana, aveia preta e azevém) das pastagens de capim-aruana exclusivo e do capim-aruana sobre-semeado com a mistura de aveia preta e azevém, em seis períodos de pastejo com ovinos.

A interação períodos de pastejo x tipos de pastagem para os teores de PB da massa total de forragem (Tabela 12) foi significativa $(P=0,0977)$. Apenas no terceiro período de pastejo (P3: 30/08 a 05/09/00), o teor de PB da massa total de forragem diferiu entre os dois tipos de pastagem, sendo maior na pastagem de capim-aruana exclusivo $(P=0,0033)$ que na pastagem sobre-semeada com as forrageiras de inverno. Neste período, houve uma boa contribuição da aveia preta e do azevém $(0,73 \mathrm{Mg}$. MS $\mathrm{ha}^{-1}$ ) no tratamento sobre-semeado (Tabela 2). Porém, os teores de PB destas forrageiras de inverno foram menores em relação aos do capim-aruana (Tabela 12), por estarem em estádio avançado de desenvolvimento e com as menores porcentagens de lâminas 
(Tabela 6), fazendo baixar os teores de PB do tratamento sobre-semeado. $\mathrm{O}$ que não aconteceu nos dois primeiros períodos de pastejo (P1: 24/05 a 01/06/00 e P2: 04/07 a 12/07/00), quando os teores de $\mathrm{PB}$ da aveia e do azevém foram mais elevados ( $P=0,0001)$ que os do terceiro e, especialmente do quarto período ( $\mathrm{P} 4: 18 / 10$ a $26 / 10 / 00$ ) para o azevém, que chegou a 9,0 \% quando as plantas hibernais já estavam na fase final do ciclo produtivo (Tabela 2). Mesmo no último período (P4), em que ocorreu o menor teor de proteína bruta, este não seria limitante para o animal, já que este valor está adequado para atender as exigências de manutenção do animal para a categoria corte (National Research Council - NRC, 1996).

Tabela 12. Teores de proteína bruta da massa de forragem e dos componentes forrageiros em pastagens de capim-aruana exclusivo (AE) e capim-aruana sobre-semeado com uma mistura de espécies forrageiras de inverno (MFI) antes da entrada dos ovinos em seis períodos de pastejo $(\mathrm{P})$ no primeiro ano de experimento

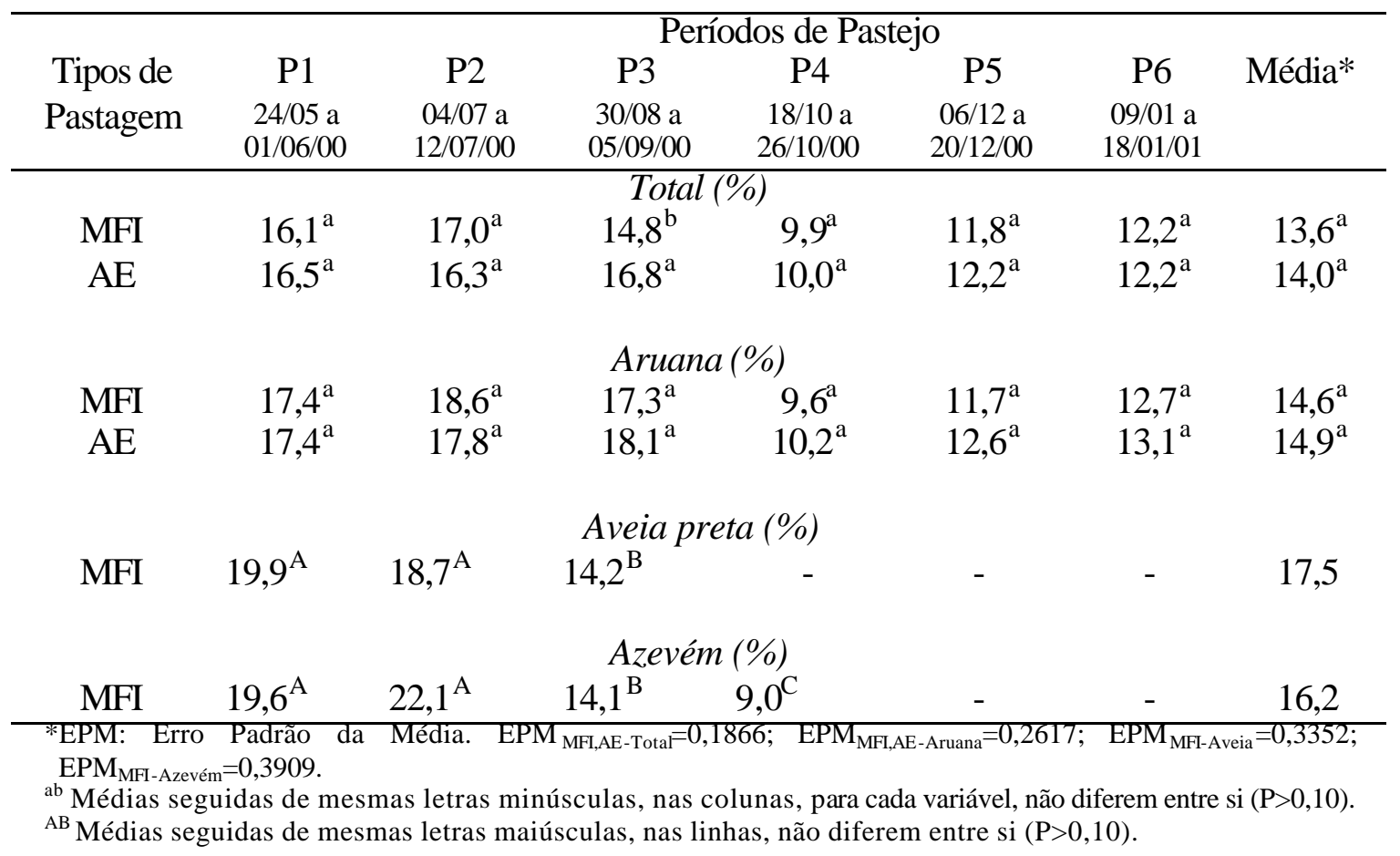


Restle et al. (2000), ao contrário dos nossos resultados, encontraram os menores teores de PB da forragem em pastagem de aveia preta + azevém no primeiro (02/06 a 02/07) e segundo (02/07 a 05/08) períodos de pastejo e o maior no terceiro (05/08 a 25/08).

Os teores de PB do componente aruana, entre as duas pastagens em estudo, foram semelhantes $(P=0,4115)$ em todos os períodos de avaliação e na sua média (Tabela 12). Os teores de PB do capim-aruana encontrados por Ghisi et al. (1989) e Cecato et al. (1994) foram inferiores aos teores de PB do presente estudo.

Zimmer (1999), trabalhando com duas alturas de pós-pastejo e duas doses de nitrogênio em capim-aruana, na estação seca do ano, obteve teor médio de proteína bruta de $18,7 \%$. Valor este próximo aos do componente aruana mostrados na Tabela 12, nos períodos referentes à estação seca do ano (P1, P2 e P3).

Nas Tabelas 13 e 14 encontram-se os dados referentes aos conteúdos FDN, FDA e lignina, respectivamente, da massa total de forragem ofertada para os animais e dos componentes forrageiros em estudo, nos dois tipos de pastagem de capim-aruana (sobresemeada e exclusiva), em seis períodos de utilização.

Os teores de FDN da massa total de forragem na pastagem sobre-semeada foram menores $(\mathrm{P}<0,10)$ em relação aos teores da pastagem exclusiva de capim-aruana, tanto na média dos períodos de pastejo $(P=0,0127)$, quanto nos dois primeiros ( $\mathrm{P} 1: P=0,0682$ e P2: $P=0,0145)$ permanecendo semelhantes $(\mathrm{P}>0,10)$ nos demais períodos de utilização das pastagens (Tabela 13).

Os mais baixos teores de FDN das duas forrageiras de inverno (Tabela 14), nos dois primeiros períodos, quando suas presenças eram em torno de 7,5 \% no P1 e 11,5\% no P2 (Tabela 2), colaboraram para a queda no teor de FDN da pastagem sobre-semeada (Tabela 13). Ainda mais que os componentes botânicos (aruana, plantas invasoras e material morto) constituintes desta pastagem, tiveram presenças semelhantes quando comparados com os componentes da pastagem exclusiva (Tabela 2), não interferindo, possivelmente, nos teores de FDN. 
Os teores de FDA e lignina da massa total de forragem (Tabela 13) também foram menores $\left(P_{F D A}=0,0123\right.$ e $\left.P_{\text {Lignina }}=0,0147\right)$ na pastagem contendo as forrageiras de inverno em relação à pastagem exclusiva, na média dos seis períodos de pastejo.

Para a variável teor de FDN do componente aruana (Tabela 14) houve interação $(P=0,0548)$ entre os períodos de pastejo e os tipos de pastagem. No quarto período, o teor de FDN do aruana na pastagem exclusiva foi maior $(P=0,0081)$ que o da pastagem sobre-semeada, não havendo diferença significativa entre os dois tipos de pastagem $(P=0,1305)$ nos demais e na média dos seis períodos, que apresentou os seguintes teores: $72,7 \%$ e $71,6 \%$ respectivamente para pastagem AE e MFI.

Tabela 13. Teores de fibra em detergente neutro, fibra em detergente ácido e lignina da massa de forragem em pastagens de capim-aruana exclusivo (AE) e capimaruana sobre-semeado com uma mistura de espécies forrageiras de inverno (MFI) antes da entrada dos ovinos em seis períodos de pastejo (P) no primeiro ano de experimento

\begin{tabular}{|c|c|c|c|c|c|c|c|}
\hline \multirow{4}{*}{$\begin{array}{l}\text { Tipos de } \\
\text { Pastagem }\end{array}$} & \multicolumn{7}{|c|}{ Períodos de Pastejo } \\
\hline & P1 & $\mathrm{P} 2$ & P3 & $\mathrm{P} 4$ & P5 & P6 & Média* \\
\hline & $24 / 05$ a & $04 / 07$ a & $30 / 08$ a & $18 / 10 \mathrm{a}$ & $06 / 12$ a & 09/01 a & \\
\hline & $01 / 06 / 00$ & $12 / 07 / 00$ & 05/09/00 & $26 / 10 / 00$ & 20/12/00 & 18/01/01 & \\
\hline \multicolumn{8}{|c|}{ Fibra em detergente neutro (\%) } \\
\hline MFI & $66.8^{\mathrm{b}}$ & $653^{\mathrm{b}}$ & $69.1^{\mathrm{a}}$ & $720^{\mathrm{a}}$ & $70,8^{\mathrm{a}}$ & $73.2^{\mathrm{a}}$ & $69.5^{\mathrm{b}}$ \\
\hline $\mathrm{AE}$ & $69,1^{\mathrm{a}}$ & $68,4^{\mathrm{a}}$ & $70,5^{\mathrm{a}}$ & $73,7^{\mathrm{a}}$ & $72,1^{\mathrm{a}}$ & $73,8^{\mathrm{a}}$ & $71,3^{\mathrm{a}}$ \\
\hline \multicolumn{8}{|c|}{ Fibra em detergente ácido (\%) } \\
\hline MFI & $35,6^{\mathrm{a}}$ & $34,0^{\mathrm{b}}$ & $34,9^{\mathrm{a}}$ & $38,8^{\mathrm{a}}$ & $38,6^{\mathrm{a}}$ & $43,3^{\mathrm{b}}$ & $37,6^{\mathrm{b}}$ \\
\hline $\mathrm{AE}$ & $36,8^{\mathrm{a}}$ & $36,3^{\mathrm{a}}$ & $36,7^{\mathrm{a}}$ & $37,8^{\mathrm{a}}$ & $39,9^{\mathrm{a}}$ & $46,1^{\mathrm{a}}$ & $38,9^{\mathrm{a}}$ \\
\hline \multicolumn{8}{|c|}{ Lignina (\%) } \\
\hline MFI & $4,5^{\mathrm{a}}$ & $4,3^{\mathrm{a}}$ & $4,7^{\mathrm{b}}$ & $4,2^{\mathrm{a}}$ & $4,0^{\mathrm{a}}$ & $5,1^{\mathrm{a}}$ & $4,4^{\mathrm{b}}$ \\
\hline $\mathrm{AE}$ & $4,8^{\mathrm{a}}$ & $4,7^{\mathrm{a}}$ & $5,4^{\mathrm{a}}$ & $4,1^{\mathrm{a}}$ & $4,0^{\mathrm{a}}$ & $5,4^{\mathrm{a}}$ & $4,9^{\mathrm{a}}$ \\
\hline$T^{2}$ & $\mathrm{aM}$ & & 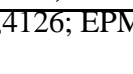 & 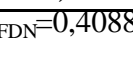 & $\mathbb{N}_{\mathrm{M} F-\mathrm{F}}$ & 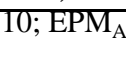 & 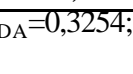 \\
\hline
\end{tabular}

Para os teores de FDA e lignina do componente aruana (Tabela 14) não houve interação $\left(P_{F D A}=0,3568\right.$ e $\left.P_{\text {Lignina }}=0,4379\right)$ entre os períodos de pastejo e tipos de 
pastagem. Também não houve diferença significativa entre os dois tipos de pastagem $\left(P_{F D A}=0,1162\right.$ e $\left.P_{\text {Lignina }}=0,8053\right)$ na média dos seis períodos. A semelhança destes teores do componente aruana entre as duas pastagens deve-se ao fato de este componente forrageiro também não apresentar diferenças $(\mathrm{P}>0,10)$ nas porcentagens de lâminas, em ambas as pastagens nos seis períodos de pastejo (Tabela 6).

Tabela 14. Teores de fibra em detergente neutro, fibra em detergente ácido e lignina dos componentes forrageiros em pastagens de capim-aruana exclusivo (AE) e capim-aruana sobre-semeado com uma mistura de espécies forrageiras de inverno (MFI) antes da entrada dos ovinos em seis períodos de pastejo $(\mathrm{P})$ no primeiro ano de experimento

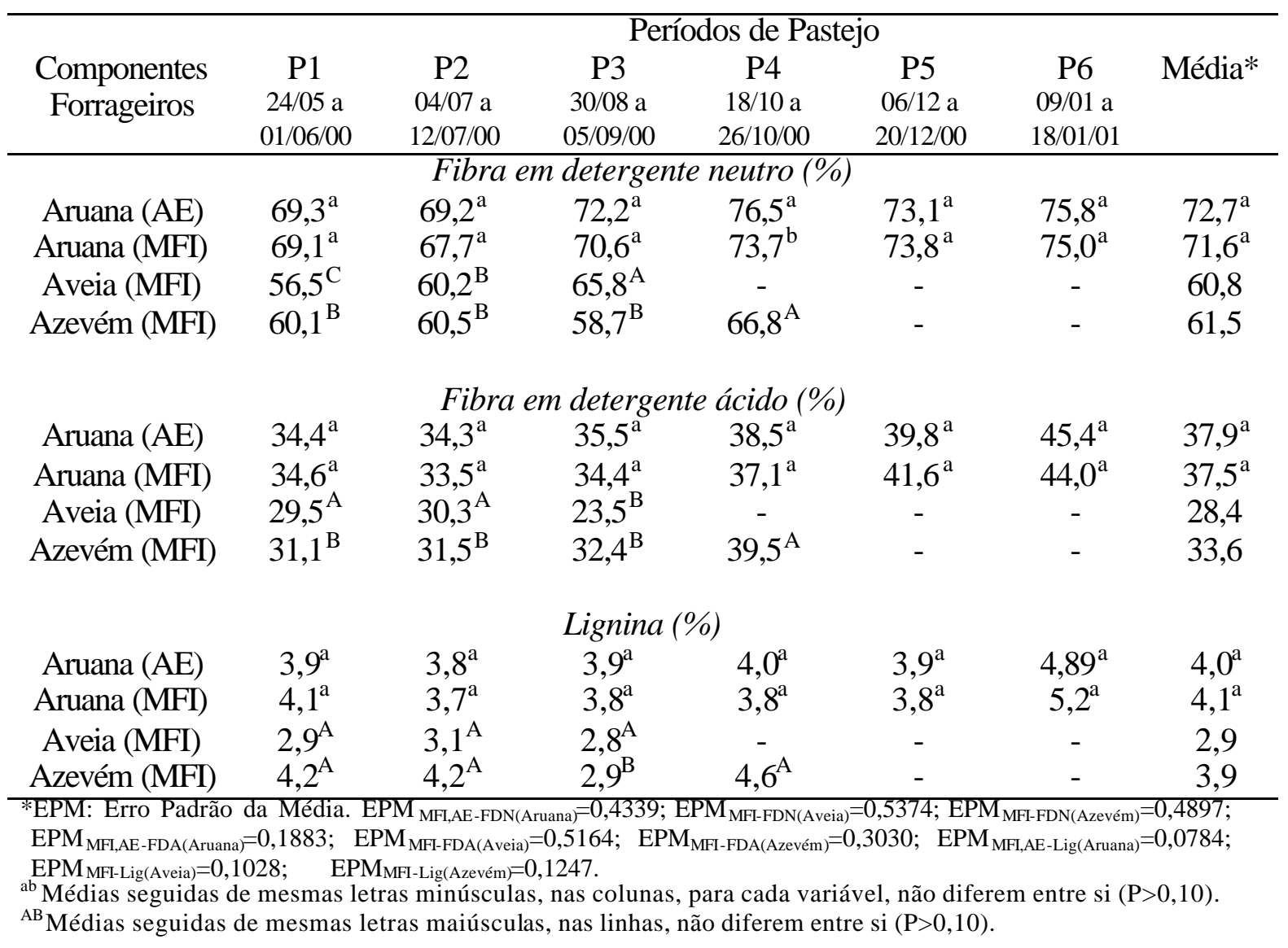


O teor de FDN da aveia preta (Tabela 14) aumentou de forma significativa $(P=0,001)$ com o avanço dos períodos de utilização da pastagem (P1: 56,5 \%; P2: 60,2 \% e P3: 65,8 \%), diferentemente dos teores de FDA e lignina, onde o FDA foi mais baixo $(\mathrm{P}<0,10)$ no último período $(\mathrm{P} 3)$ e a lignina manteve-se com os teores semelhantes ao logo dos três períodos.

$\mathrm{O}$ azevém apresentou acentuado aumento $(\mathrm{P}=0,0001)$ dos teores de FDN e FDA (Tabela 14) no período final (P4) do seu ciclo de crescimento, em relação aos três períodos anteriores, que tiveram teores mais baixos e semelhantes $(\mathrm{P}>0,10)$, concordando com a afirmação de Blaser (1964), de que com o avanço dos estádios de maturação há acelerado acúmulo de carboidratos estruturais na parede celular das plantas forrageiras.

Os valores de digestibilidade "in vitro" da massa seca total de forragem e dos seus componentes na pastagem de capim-aruana contendo a mistura das forrageiras de inverno e na exclusiva, ao longo dos seis períodos de utilização das mesmas, são mostrados na Tabela 15 .

Não existiu diferença significativa entre os dois tipos de pastagem na média dos seis períodos de pastejo, para a DIVMS da massa total de forragem $(P=0,4423)$ e da do aruana $(P=0,2903)$, que tiveram valores de $68,7 \%$ e $68,0 \%$ para a massa total de forragem e de $71,3 \%$ e 70,6 \% para o componente aruana, respectivamente na pastagem de aruana com sobre-semeadura e testemunha (Tabela 15). Esperava-se, de acordo com Reis et al. (1993), maior digestibilidade no tratamento do capim-aruana sobre-semeado. O que não ocorreu, porque o aruana, tanto no tratamento exclusivo, como no sobresemeado, apresentou elevadas porcentagens de digestibilidade (Tabela 15) e de proteína bruta (Tabela 12), devido às condições de adubação, irrigação e manejo adequados, mostrando que, com estas práticas conjugadas, a sobre-semeadura de forrageiras de inverno, neste capim, seria desnecessária para melhorar o valor nutritivo de pastagens de capim-aruana.

Há forte relação da proteína bruta, componente nutricional julgado como indicador quantitativo, e a digestibilidade das forragens (Van Soest, 1982), como demonstrou os nossos resultados, quanto a estas determinações realizadas no aruana. 
As digestibilidades da aveia e do azevém decresceram $(P=0,0001)$ ao final dos seus ciclos de crescimento (Tabela 15). Os mais baixos teores de FDN e FDA do azevém (Tabela 14), nos três primeiros períodos (P1, P2 e P3), comparados com o P4 correspondem aos mais altos valores de DIVMS (Tabela 15). Relação inversa, quanto ao teor de FDN e digestibilidade, foi observada por Gomes \& Reis (1999) com forrageiras de inverno.

Tabela 15. Digestibilidade "in vitro" da matéria seca da massa total de forragem e dos seus componentes forrageiros em pastagens de capim-aruana exclusivo (AE) e capim-aruana sobre-semeado com uma mistura de forrageiras de inverno (MFI) antes da entrada dos ovinos em seis períodos de pastejo (P) no primeiro ano de experimento

\begin{tabular}{|c|c|c|c|c|c|c|c|}
\hline \multirow{4}{*}{$\begin{array}{l}\text { Tipos de } \\
\text { Pastagem }\end{array}$} & \multicolumn{7}{|c|}{ Períodos de Pastejo } \\
\hline & P1 & P2 & P3 & P4 & P5 & P6 & Média* \\
\hline & $24 / 05$ a & 04/07 a & $30 / 08$ a & $18 / 10 \mathrm{a}$ & $06 / 12 \mathrm{a}$ & 09/01 a & \\
\hline & $01 / 06 / 00$ & $12 / 07 / 00$ & $05 / 09 / 00$ & $26 / 10 / 00$ & $20 / 12 / 00$ & $18 / 01 / 01$ & \\
\hline \multicolumn{8}{|c|}{ Total (\%) } \\
\hline MFI & $70,6^{\mathrm{a}}$ & $69,1^{\mathrm{a}}$ & $70,8^{\mathrm{a}}$ & $65,8^{\mathrm{a}}$ & $70,2^{\mathrm{a}}$ & $66,6^{\mathrm{a}}$ & $68,7^{\mathrm{a}}$ \\
\hline $\mathrm{AE}$ & $68,7^{\mathrm{a}}$ & $70,6^{\mathrm{a}}$ & $67,8^{\mathrm{a}}$ & $66,1^{\mathrm{a}}$ & $70,1^{\mathrm{a}}$ & $64,9^{\mathrm{a}}$ & $68,0^{\mathrm{a}}$ \\
\hline \multicolumn{8}{|c|}{ Aruana (\%) } \\
\hline MFI & $72,2^{\mathrm{a}}$ & $75,4^{\mathrm{a}}$ & $72,6^{\mathrm{a}}$ & $68,9^{\mathrm{a}}$ & $72,3^{\mathrm{a}}$ & $66,1^{\mathrm{a}}$ & $71,3^{\mathrm{a}}$ \\
\hline $\mathrm{AE}$ & $71,9^{\mathrm{a}}$ & $73,0^{\mathrm{a}}$ & $74,9^{\mathrm{a}}$ & $68,1^{\mathrm{a}}$ & $71,1^{\mathrm{a}}$ & $64,5^{\mathrm{a}}$ & $70,6^{\mathrm{a}}$ \\
\hline \multicolumn{8}{|c|}{ Aveia Preta (\%) } \\
\hline MFI & $77,5^{\mathrm{A}}$ & $76,8^{\mathrm{AB}}$ & $75,0^{\mathrm{B}}$ & - & - & - & 76,4 \\
\hline \multicolumn{8}{|c|}{ Azevém (\%) } \\
\hline MFI & $76,7^{\mathrm{A}}$ & $76,9^{\mathrm{A}}$ & $72,9^{\mathrm{A}}$ & $61,4^{\mathrm{B}}$ & - & - & 71,9 \\
\hline $\begin{array}{l}\text { EPM: Erro } \\
\text { EPM }_{\text {MF-Av }}\end{array}$ & ẫo da Mé & $\begin{array}{l}\mathrm{EPM}_{\text {MF-T }} \\
\text { A-Azevém }=0,6\end{array}$ & ,6421;EPI & Tota $=0,641$. & $\mathrm{M}_{\text {MFl-Aru }}$ & $4254 ; \mathrm{EPM}_{\mathrm{A}}$ & $=0,4262$ \\
\hline
\end{tabular}




\subsubsection{Segundo Ano Experimental - Composição química e digestibilidade da massa de forragem e dos componentes forrageiros}

Os teores de proteína bruta da massa total de forragem e dos seus componentes forrageiros (aruana, aveia preta e azevém) das pastagens de capim-aruana exclusivo e do capim-aruana sobre-semeado com a mistura de aveia preta e azevém, em seis períodos de pastejo com ovinos (segundo ano experimental), estão apresentados na Tabela 16.

Tabela 16. Teores de proteína bruta da massa total de forragem e dos seus componentes forrageiros em pastagens de capim-aruana exclusivo (AE) e capim-aruana sobre-semeado com uma mistura de espécies forrageiras de inverno (MFI) antes da entrada dos ovinos em seis períodos de pastejo $(\mathrm{P})$ no segundo ano de experimento

\begin{tabular}{|c|c|c|c|c|c|c|c|}
\hline \multirow{4}{*}{$\begin{array}{l}\text { Tipos de } \\
\text { Pastagem }\end{array}$} & \multicolumn{7}{|c|}{ Períodos de Pastejo } \\
\hline & P1 & P2 & P3 & $\mathrm{P} 4$ & P5 & P6 & Média* \\
\hline & $27 / 07 \mathrm{a}$ & 06/09 a & $22 / 10 \mathrm{a}$ & $26 / 11 \mathrm{a}$ & $02 / 01$ a & 06/02 a & \\
\hline & 06/08/01 & $16 / 09 / 01$ & $02 / 11 / 01$ & $11 / 12 / 01$ & $14 / 01 / 02$ & $22 / 02 / 02$ & \\
\hline \multicolumn{8}{|c|}{ Total (\%) } \\
\hline MFI & $17,0^{\mathrm{a}}$ & $14,6^{\mathrm{a}}$ & $11,3^{\mathrm{a}}$ & $14,0^{\mathrm{a}}$ & $11,4^{\mathrm{a}}$ & $11,4^{\mathrm{a}}$ & $13,3^{\mathrm{a}}$ \\
\hline $\mathrm{AE}$ & $17,4^{\mathrm{a}}$ & $15,5^{\mathrm{a}}$ & $12,9^{\mathrm{a}}$ & $11,1^{\mathrm{b}}$ & $11,5^{\mathrm{a}}$ & $11,8^{\mathrm{a}}$ & $13,4^{\mathrm{a}}$ \\
\hline \multicolumn{8}{|c|}{ Aruana (\%) } \\
\hline MFI & $17,1^{\mathrm{a}}$ & $16,4^{\mathrm{a}}$ & $11,8^{\mathrm{a}}$ & $12,9^{\mathrm{a}}$ & $11,4^{\mathrm{a}}$ & $12,0^{\mathrm{a}}$ & $13,6^{\mathrm{a}}$ \\
\hline $\mathrm{AE}$ & $18,8^{\mathrm{a}}$ & $16,3^{\mathrm{a}}$ & $11,7^{\mathrm{a}}$ & $11,8^{\mathrm{a}}$ & $11,9^{\mathrm{a}}$ & $12,5^{\mathrm{a}}$ & $13,8^{\mathrm{a}}$ \\
\hline \multicolumn{8}{|c|}{ Aveia Preta (\%) } \\
\hline MFI & $20,3^{\mathrm{A}}$ & $14,3^{\mathrm{B}}$ & - & - & - & - & 17,8 \\
\hline \multicolumn{8}{|c|}{ Azevém (\%) } \\
\hline MFI & $21,7^{\mathrm{A}}$ & $19,3^{\mathrm{B}}$ & $11,9^{\mathrm{C}}$ & & - & - & 18,7 \\
\hline
\end{tabular}

Houve interação $(P=0,0260)$ entre períodos de pastejo e tipos de pastagem quando se avaliou o teor de proteína bruta da massa total de forragem. No quarto 
período de pastejo ( $\mathrm{P} 4: 26 / 11$ a 11/12/01), a massa total de forragem da pastagem exclusiva de capim-aruana apresentou menor $(P=0,0024)$ teor de proteína bruta em relação ao da pastagem sobre-semeada (Tabela 16). Nos demais períodos, os teores de PB foram semelhantes $(\mathrm{P}>0,10)$ entre os dois tratamentos. $\mathrm{O}$ mesmo acontecendo na média dos seis períodos $(P=0,7522)$ com $13,3 \%$ e $13,4 \%$, respectivamente para MFI e $\mathrm{AE}$.

Para o teor de PB do componente aruana (Tabela 16), a interação entre períodos de pastejo e tipos de pastagem foi significativa $(P=0,0174)$. Mas os resultados para todos os períodos de avaliação, assim como na sua média foram semelhantes $(P=0,8403)$ entre as duas pastagens. Os teores médios de PB para ambas as alternativas de pastagem foram superiores aos teores de PB encontrados por Ghisi et al. (1989) e Cecato et al. (1994) em pastagem de capim-aruana.

Tanto para a aveia preta quanto para o azevém, os teores de PB decresceram ao longo dos períodos de pastejo, no qual estiveram presentes (Tabela 16). Mediante a estes resultados, com o avanço dos estádios de maturação das espécies forrageiras de inverno, ocorre o acúmulo de carboidratos estruturais na parede celular das plantas forrageiras, diluição da concentração de nitrogênio e, consequentemente, a diminuição do teor de proteína bruta, reforçando as afirmações de Blaser (1964), Van Soest (1982), Floss (1988), Lupatini et al. (1998b).

Na Tabela 17 encontram-se os teores de FDN, FDA e lignina da massa total de forragem nas pastagens de capim-aruana sobre-semeadas com aveia preta e azevém e nas exclusivas, ao longo de seis períodos de pastejo. Os teores, na média dos seis períodos de utilização foram semelhantes $(\mathrm{P}>0,10)$ entre as duas pastagens

$\mathrm{Na}$ Tabela 18 também encontraram-se os teores de FDN, FDA e lignina determinadas nos componentes forrageiros das duas pastagens em estudo, nos seis períodos de pastejo. Com exceção do FDA no componente aruana, que foi mais elevado $(P=0,0679)$ na pastagem contendo a mistura das forrageiras de inverno, na média dos períodos de avaliação, os outros dois constituintes da parede celular componente aruana também foram semelhantes $(\mathrm{P}>0,10)$ entre as duas alternativas de pastagens, na média dos períodos de pastejo. 
A aveia preta (Tabela 18) apresentou menores teores de FDN $(P=0,0007)$ e lignina $(P=0,0421)$ no primeiro período de pastejo aumentando-os no segundo período, já no final do seu ciclo vegetativo. Os teores de FDA da aveia foram semelhantes $(P=0,7350)$ entre os dois ciclos de pastejo em que esteve presente. Estas características qualitativas, com exceção do teor de FDA, elevaram-se com a maturidade fisiológica da aveia, que ao finalizar o seu ciclo (P2) apresentava as menores porcentagens de lâminas foliares em relação ao ciclo inicial (Tabela 11).

Tabela 17. Teores de fibra em detergente neutro, fibra em detergente ácido e lignina da massa total de forragem em pastagens de capim-aruana exclusivo (AE) e capim-aruana sobre-semeado com uma mistura de espécies forrageiras de inverno (MFI) antes da entrada dos ovinos em seis períodos de pastejo (P) no segundo ano de experimento

\begin{tabular}{|c|c|c|c|c|c|c|c|}
\hline \multirow{4}{*}{$\begin{array}{l}\text { Tipos de } \\
\text { Pastagem }\end{array}$} & \multicolumn{7}{|c|}{ Períodos de Pastejo } \\
\hline & P1 & $\mathrm{P} 2$ & P3 & $\mathrm{P} 4$ & P5 & P6 & Média* \\
\hline & $27 / 07 \mathrm{a}$ & 06/09 a & $22 / 10 \mathrm{a}$ & $26 / 11 \mathrm{a}$ & $02 / 01 \mathrm{a}$ & $06 / 02$ a & \\
\hline & 06/08/01 & 16/09/01 & 02/11/01 & $11 / 12 / 01$ & $14 / 01 / 02$ & $22 / 02 / 02$ & \\
\hline \multicolumn{8}{|c|}{ Fibra em detergente neutro (\%) } \\
\hline MFI & $64,7^{\mathrm{a}}$ & $65,7^{\mathrm{b}}$ & $71,4^{\mathrm{a}}$ & $70,7^{\mathrm{a}}$ & $72,8^{\mathrm{a}}$ & $73,1^{\mathrm{a}}$ & $69,7^{\mathrm{a}}$ \\
\hline $\mathrm{AE}$ & $66,7^{\mathrm{a}}$ & $69,5^{\mathrm{a}}$ & $71,8^{\mathrm{a}}$ & $72,2^{\mathrm{a}}$ & $71,3^{\mathrm{a}}$ & $72,9^{\mathrm{a}}$ & $70,7^{\mathrm{a}}$ \\
\hline \multicolumn{8}{|c|}{ Fibra em detergente ácido (\%) } \\
\hline MFI & $34,3^{\mathrm{a}}$ & $34,2^{\mathrm{a}}$ & $39,0^{\mathrm{a}}$ & $38,8^{\mathrm{a}}$ & $43,7^{\mathrm{a}}$ & $42,4^{\mathrm{a}}$ & $38,7^{\mathrm{a}}$ \\
\hline $\mathrm{AE}$ & $34,6^{\mathrm{a}}$ & $35,8^{\mathrm{a}}$ & $38,0^{\mathrm{a}}$ & $40,1^{\mathrm{a}}$ & $42,7^{\mathrm{a}}$ & $41,7^{\mathrm{a}}$ & $38,8^{\mathrm{a}}$ \\
\hline \multicolumn{8}{|c|}{ Lignina (\%) } \\
\hline MFI & $4,1^{\mathrm{a}}$ & $3,9^{\mathrm{a}}$ & $3,6^{\mathrm{a}}$ & $4,0^{\mathrm{a}}$ & $5,2^{\mathrm{a}}$ & $4,4^{\mathrm{a}}$ & $4,2^{\mathrm{a}}$ \\
\hline $\mathrm{AE}$ & $4,3^{\mathrm{a}}$ & $3,8^{\mathrm{a}}$ & $3,7^{\mathrm{a}}$ & $3,8^{\mathrm{a}}$ & $5,0^{\mathrm{a}}$ & $4,5^{\mathrm{a}}$ & $4,2^{\mathrm{a}}$ \\
\hline
\end{tabular}

Os menores teores de FDN e FDA do azevém $(P=0,0001)$ foram encontrados no primeiro e segundo períodos e os maiores, no último período de pastejo (P3), como mostra a Tabela 18. No terceiro período o azevém apresentou a menor proporção de lâminas em relação às hastes (Tabela 11), característica esta que afetou negativamente a 
Lupatini et al. (1998b), trabalhando com níveis de nitrogênio em aveia preta mais azevém em pastejo, de meados de julho até final de outubro, também encontraram queda no valor nutritivo destas forrageiras com o avanço nos períodos de pastejo.

Os valores da DIVMS da massa total de forragem dos componentes forrageiros encontram-se na Tabela 19. Não houve diferença $(P=0,4333)$ entre os tipos de pastagens quando se avaliou a digestibilidade da forragem oferecida para os animais, ao longo dos períodos de pastejo.

Tabela 19. Digestibilidade "in vitro" da matéria seca da massa total de forragem e dos seus componentes forrageiros em pastagens de capim-aruana exclusivo (AE) e capim-aruana sobre-semeado com uma mistura de espécies forrageiras de inverno (MFI) antes da entrada dos ovinos, em seis períodos de pastejo (P), no segundo ano de experimento

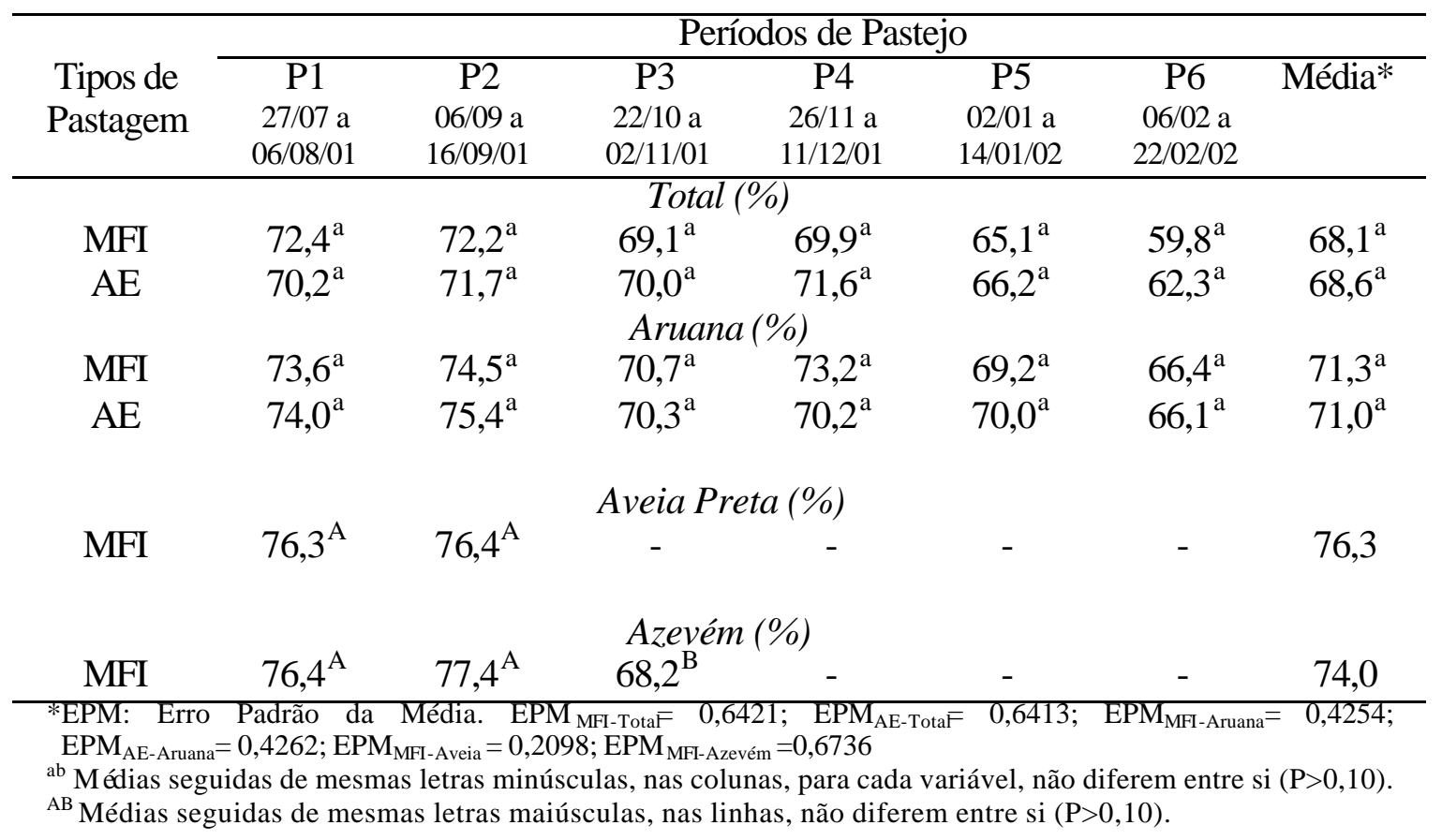

Roso et al. (1999), avaliando a qualidade da forragem ofertada contendo diferentes misturas de gramíneas anuais de estação fria (triticale + azevém, aveia preta + 
azevém e triticale + aveia preta + azevém) sob pastejo, verificaram que os três tipos de pastagens apresentaram teores semelhantes de DIVMO.

Para a DIVMS do componente aruana (Tabela 19) a interação períodos de pastejo $\mathrm{x}$ tipos de pastagem foi significativa $(P=0,0132)$. Na média dos seis períodos não houve diferença significativa $(P=0,5368)$ entre a pastagem de capim-aruana sobresemeada e a exclusiva, obtendo-se valores considerados elevados quanto à exploração de pastagens, em ambiente tropical: $71,3 \%$ e $71,0 \%$ respectivamente para a pastagem de capim-aruana com a MFI e a de AE.

A aveia preta apresentou os melhores resultados de PB e consituintes da parede celuar (Tabelas 16 e 18) na avaliação inicial (P1), quando as espécies se encontravam em pleno estádio de crescimento vegetativo, em relação à avaliação seguinte (P2), onde a aveia finalizava o seu ciclo. Mas, analisando a digestibilidade deste componente (Tabela 19) foram constatados valores semelhantes $(P=0,7239)$ desta variável entre os dois períodos de pastejo, contrariando as expectativas baseadas nos teores de PB e fibras e discordando dos resultados obtidos por Lupatini et al. (1998b), Roso et al. (1999) e Restle et al. (2000).

Os valores de DIVMS do azevém (Tabela 19) mantiveram-se constantes nos primeiros dois períodos de pastejo, que foram maiores em relação ao último, onde ocorreu redução acentuada, devido aos maiores valores de FDN, FDA e lignina (Tabela 18) e ao menor teor de proteína bruta (Tabela 16).

\subsection{Conclusões}

Houve acentuada redução no valor nutritivo das espécies forrageiras de inverno, ao longo do período de utilização, coincidindo com o que ocorre nas espécies forrageiras de clima tropical com o avanço na idade da planta.

$\mathrm{Na}$ maioria dos períodos de pastejo, os teores de FDN, FDA e lignina encontrados nas pastagens de capim-aruana exclusivo e naquelas contendo a mistura de aveia preta e azevém foram semelhantes. As digestibilidades da forragem ofertada, nos 
dois tipos de pastagem, também foram semelhantes em todos os períodos de pastejo e na sua média.

Pastos de capim-aruana, que recebam adubação nitrogenada, irrigação e manejo adequados, apresentam composição química e digestibilidade semelhantes às de pastos do capim sobre-semeados com aveia preta e azevém. 


\section{CONCLUSÕES}

Pastagens de capim-aruana convenientemente adubadas e irrigadas no outono/inverno e que recebam sobre-semeadura com espécies forrageiras de inverno produzem mais forragem, no período crítico do ano, em relação a pastagens desse capim não sobre-semeadas, nas condições do Estado de São Paulo.

Pastagens de capim-aruana adubadas e irrigadas no outono/inverno e que recebam sobre-semeadura com espécies forrageiras de inverno apresentam valor nutritivo semelhante, no período crítico do ano, em relação a pastagens desse capim não sobre-semeadas, nas condições do Estado de São Paulo.

Pastagens de capim-aruana, não sobre-semeadas com espécies forrageiras de inverno, mas que recebam adubação e irrigação outono/inverno, apresentam boa produção e valor nutritivo. 


\section{REFERÊNCIAS BIBLIOGRÁFICAS}

ALVIM, M.J.; CÓSER, M.J. Aveia e azevém anual: recursos forrageiros para a época da seca. In: CARVALHO, M.M.; ALVIM, M.J. (Ed.). Pastagens para gado de leite em regiões de influência da mata atlântica. Brasília: EMBRAPA, 2000. p. 83107.

ALVIM, M.J.; MOZZER, O.L. Efeitos da época de plantio e da idade do azevém anual (Lolium multiflorum L.) sobre a produção de forragem e teor de proteína bruta. Revista da Sociedade Brasileira de Zootecnia, v.13, n 4, p.535-541, 1984.

ALVIM, M.J.; OLIVEIRA, J.G.; RAMALHO, G. et al. Influência do pasto de azevém (Lolium multiflorum L.) na produção de leite de vacas mestiças na região do Alto Paranaíba, Minas Gerais. In: REUNIÃO ANUAL DA SOCIEDADE BRASILEIRA DE ZOOTECNIA, 24., Brasília, 1987. Anais. Brasília : SBZ, 1987. p.221.

ANDRADE, I.F. de; FERREIRA, J.C.; CARVALHO, M.M. de et al. Competição entre forrageiras de inverno. Revista Brasileira de Zootecnia, v.4, n.1, p.1-11, 1975.

ASSOCIATION OF OFFICIAL ANALYTICAL CHEMISTS. Micro Kjeldahl næthod. In: CUNNIFF, P. (Ed.). Official methods of analysis of AOAC International. Arlington, 1995. cap. 12, p. 7. 
BLASER, R.E. Symposium on forage utilization: effects of fertility levels and stage of maturity on forage nutritive value. Journal of Animal Science, v.23, p.246-253, 1964.

BOTREL, M. A.; NOVELLY, P.E. Produção estacional de matéria seca de aveia e azevém irrigados na Zona da Mata de Minas Gerais. Coronel Pacheco: EMBRAPA, CNPGL, 1982. 18p. (EMBRAPA. CNPGL. Boletim de Pesquisa, 8).

CARDOSO, R.M. Culturas forrageiras de inverno e sua utilização. In: SIMPÓSIO SOBRE MANEJO DA PASTAGEM 6., Piracicaba, 1986. Anais. Piracicaba: FEALQ, 1986. p.349-357.

CARDOSO, R.M.; PACHECO, E.; CARVALHO, D.G. et al. Competição entre variedades forrageiras de inverno. In: REUNIÃO ANUAL DA SOCIEDADE BRASILEIRA DE ZOOTECNIA, 9., Viçosa, 1972. Anais. Viçosa : SBZ, 1972. p.279.

CECATO, U.; FAVORETTO, V.; MALHEIROS, E.B. Freqüências de corte, níveis e formas de aplicação de nitrogênio sobre a composição bromatológica de capimAruana (Panicum maximum Jacq. cv Aruana). Revista UNIMAR, v.16, n.3, p.277291, 1994.

CECATO,U.; BARBOSA, M.A.A. F.; SAKAGUTI, E.S. et al. Avaliação de cultivares de Panicum maximum Jacq. In: REUNIÃO ANUAL DA SOCIEDADE BRASILEIRA DE ZOOTECNIA, 33., Fortaleza, 1996. Anais. Fortaleza: SBZ, 1996. p.109-111.

CECATO, U.; SARTI, L.L.; SAKAGUTI, E.S. et al. Avaliação de cultivares e linhagens de aveia (Avena spp.) Acta Scientiarum, v.20, n.3, p.347-354, 1998. 
COLOZZA, M.T. Rendimento e diagnose foliar dos capins aruana e mombaça cultivados em latossolo vermelho-amarelo adubado com doses de nitrogênio. Piracicaba, 1998. 127 p. Tese (Doutorado) - Escola Superior de Agricultura "Luiz de Queiroz", Universidade de São Paulo.

COOPER, J. P. Potencial production and energy conversion in temperate and tropical grasses. Herbage Abstracts, v.40, n.1, p.1-15, 1970.

COOPER, J.P.; TAINTON, N.M. Ligth and temperature requirements for the growth of tropical and temperate grasses. Review article. Herbage Abstracts, v.38, p. 167176, 1968.

CUNHA, E.A.; SANTOS. L.E., BUENO; M.S. et al. Sistema intensivo de produção ovina. Nova Odessa: Instituto de Zootecnia, 1999. 22 p.

EMPRESA BRASILEIRA DE PESQUISA AGROPECUÁRIA. Sistema brasileiro de classificação de solos. Brasília, 1999. 412p.

EUCLIDES, V.P.B.; MACEDO, M.C.M; ZIMMER, A.H. et al. Valores nutritivos de cinco gramíneas sob pastejo. In: REUNIÃO DA SOCIEDADE BRASILEIRA DE ZOOTECNIA, 33., Fortaleza, 1996. Anais. Fortaleza: SBZ, 1996. p.90-92.

FLOSS, E.L. Manejo forrageiro de aveia (Avena SP) e azevém (Lolium SP). In: SIMPÓSIO SOBRE MANEJO DA PASTAGEM, 9., Piracicaba, 1988. Anais. Piracicaba: FEALQ, 1988. p.231-268.

FRIBOURG, H.A.; OVERTON, J.R. Forage production on bermuda grass overseeds with tall fescue and winter annual grasses. Agronomy Journal, v.65, p.295-298, 1973. 
GHELFI FILHO, H. Efeito da irrigação sobre a produtividade do capim elefante (Pennisetum purpureum Schum.) variedade Napier. Piracicaba, 1972. 77 p. Tese (Doutorado) - Escola Superior de Agricultura "Luiz de Queiroz", Universidade de São Paulo.

GHISI, O.M.A.; ALMEIDA, A.R.P. de; ALCÂNTARA, V.B.G. Avaliação agronômica de seis cultivares de Panicum maximum Jacq. sob três níveis de adubação. Boletim de Indústria Animal, v.46, n.1, p.1-15, 1989.

GODOY, R.; NOVAES, N.J.; CORREA, L.A. et al. Avaliação preliminar de cultivares de aveia na região de São Carlos, SP. In: REUNIÃO ANUAL DA SOCIEDADE BRASILEIRA DE ZOOTECNIA, 23., Campo Grande, 1986. Anais. Campo Grande : SBZ, 1986. p.185.

GOERING, N.K.;VAN SOEST, P.J. Forage fiber analysis: apparatus, reagents, procedures and some application. Washinghton, 1970. 20p. (USDA. Agriculture Handbook).

GOMES, J.F.; REIS, JCL. Produção de forrageiras anuais de estação fria no litoral sul do Rio Grande do Sul. Revista Bras ileira de Zootecnia, v.28, n.4, p.668-674, 1999.

GOMIDE, J.A. Formação e utilização de capineira de capim elefante. In: SIMPÓSIO SOBRE CAPIM-ELEFANTE, Coronel Pacheco, 1990. Anais. Coronel Pacheco: EMBRAPA, CNPGL, 1990. p. 59-87.

GOMIDE, C.M.A.; GOMIDE, J.A.; QUEIROZ, D.S. et al. Fluxo de tecidos em Brachiaria decumbens. In: REUNIÃO ANUAL DA SOCIEDADE BRASILEIRA DE ZOOTECNIA, 34., Juiz de Fora, 1997. Anais. Juiz de Fora: SBZ, 1997. p. 117119. 
GUSS, A.; DESSAUNE FILHO, N.; BARBOSA, M.A. Competição de forrageiras de Inverno em duas regiões do Espírito Santo. Cariacica: EMCAPA, 1981. 12p. (EMCAPA. Boletim Técnico, 4).

HODGSON, J. Herbage production and utilization: grazing management - science into practice. New York: John Wiley, 1990. p.38-54.

INSTITUTO DE ZOOTECNIA. Capim aruana (Panicum maximum Jacq. cv. Aruana IZ-5): pré-lançamento. Nova Odessa, 1989.

JANK, L.; SAVIDAN, Y.H.; SOUZA, M.T.C. de, et al. Avaliação do germoplasma de Panicum maximum introduzida da África: 1. Produção forrageira. Revista Brasileira de Zootecnia, v.23, n.3, p. 433-440, 1994.

JOHnSON, J.T.; LEE, R.D. Pasture in Georgia. Athens: University of Georgia, 1997. 36p. (Bulletin, 573).

LEMAIRE, G.; CHAPMAN, D. Tissue flows in grazed plant comunities. In: HODGSON, J.; ILLIUS, E. (Ed.). The ecology and management of grazing systems. London: CAB International, 1996. cap. 1, p. 3-36.

LITTELL, R. C.; MILLIKEN, G. A.; STROUP, W. W. et al. SAS ${ }^{\circledR}$ system for mixed models. Cary: SAS Institute, 1996. 633p.

LUPATINI, G.C.; NEUMANN, M.; ALVES, S.R. et al. Avaliação da produção de forragem de espécies de estação fria. In REUNIÃO ANUAL DA SOCIEDADE BRASILEIRA DE ZOOTECNIA 35., Botucatu, 1998a. Anais. Botucatu : SBZ, 1998a. p.134-136. 
LUPATINI, G.C.; RESTLE, J.; CERETTA, M. et al. Avaliação da mistura de aveia preta (Avena strigosa) e azevém (Lolium multiflorum ) sob pastejo submetida a níveis de nitrogênio. I - Produção e qualidade de forragem. Pesquisa Agropecuária Brasileira, v.23, n.11, p.1939-1943, 1998b.

MAIA, M.S.; BUSO, L.H.; MENDES, M.E.G. Plantio direto de azevém anual (Lolium multiflorum Lam.) e aveia preta (Avena strigosa schreb.) em campo nativo: 2. qualidade de forragem (compact disc). In: REUNIÃO DA SOCIEDADE BRASILEIRA DE ZOOTECNIA, 35., Botucatu, 1998. Anais. Botucatu: SBZ, 1998.

MATZ, S.A. Oats. Cereal Science, v.8, p.78-96, 1969.

MONTEIRO, A.L.G.; MORAES, A. Fisiologia e morfologia de plantas forrageiras. In: MONTEIRO, A.L.G.; MORAES, A.; CORRÊA, E.A.S. et al. (Ed.) Forragicultura no Paraná. Londrina: CPAF, 1996. p.75-92.

MORAES, A. de; LUSTOSA, S.B.C. Forrageiras de Inverno como alternativas na alimentação animal em períodos críticos. In: SIMPÓSIO SOBRE NUTRIÇÃO DE BOVINOS, 7., Piracicaba, 1999. Anais. Piracicaba: FEALQ, 1999. p.147-166.

MOREIRA, A.L.; REIS, R.A.; BARBOSA, J.C. et al. Sobressemeadura das espécies de inverno no capim tifton-85. produção e distribuição das forrageiras (compact disc). In: REUNIÃO DA SOCIEDADE BRASILEIRA DE ZOOTECNIA, 39., Recife, 2002. Anais. Recife: SBZ, 2002.

MOREIRA, A.L.; SEIXAS, P.F.; REIS, R.A. et al. Avaliação de cinco cultivares de Avena spp. para a produção de forragem em Jaboticabal, SP. In: REUNIÃO ANUAL DA SOCIEDADE BRASILEIRA DE ZOOTECNIA, 38., Piracicaba, 2001. Anais. Piracicaba: SBZ, 2001. p.96-98. 
MOTTA, V.A.F. da; CARDOSO, R.M.; SILVA, J.F.C. da et al. Aveia forrageira (Avena bizantina, L) nas formas verde e fenada e silagem de milho na alimentação de vacas em lactação. Revista Brasileira de Zootecnia, v.9, n. 3, p. 430-440, 1980.

NATIONAL RESEARCH COUNCIL. Nutrient requirement of beef cattles. 6 . ed. Washington: National Academic Press, 1996. 90 p.

PEDREIRA, J.V.S. Crescimento estacional dos capins colonião Panicum maximum Jacq., gordura Melinis minutiflora Pal de Beauv., jaraguá Hyparrhenia rufa (Ness) Stapf e pangola de Taiwan A-24 Digitaria pentzii Stent. Boletim de Indústria Animal, v.30, n.1, p.59-145, 1973.

POSTIGLIONI, S.R. Comportamento da aveia, azevém e centeio na região dos Campos Gerais, PR. Londrina: IAPAR, 1982. 18 p. (IAPAR. Boletim Técnico, 14).

PRIMAVESI, A.C. Resposta da aveia cultivar São Carlos à adubação NPK, em dois tipos de solo, no Estado de São Paulo. In: RESUMOS DA REUNIÃO DA COMISSÃO BRASILEIRA DE AVEIA, 18., Londrina, 1998. Anais. Londrina: IAPAR,1998. p. 83-85.

REIS, R.A.; FONTANELI, R.S. Melhoramento de pastagens através de introdução de forrageiras de inverno visando maximizar o uso do solo. In: SIMPÓSIO DE FORRAGICULTURA E PASTAGENS: temas em evidência, Lavras, 2000. Anais. Lavras: UFLA, 2000. p.237 -271.

REIS, R.A.; RODRIGUES, L.R.A.; COAN, O. et al. Produção e qualidade da forragem de aveia (Avena spp.). Revista Brasileira de Zootecnia, v.22, n.1, p.99-109, 1993. 
REIS, R.A.; SOLLENBERGER, L.E.; URBANO, D. Impact of overseeding cool-season annual forages on spring regrowth of Tifton 85 bermudagrass. In: INTERNATIONAL GRASSLAND CONGRESS, 19., São Pedro, 2001. Proceedings. São Pedro: Brazilian Society of Animal Husbandry, 2001. p.295-297.

RESTLE, J; ROSO, C.; SOARES, A.B. et al. Produtividade Animal e retorno econômico em pastagem de aveia preta mais azevém adubada com fontes de nitrogênio em cobertura. Revista Brasileira de Zootecnia, v.29, n.2, p.357-364, 2000 .

RODRIGUES, L.R.A.; RODRIGUES, T.J.D. Ecofisiologia de plantas forrageiras. In: CASTRO, P.R.C.; FERREIRA, S.O.; YAMADA, T. et al. (Ed.). Ecofisiologia da produção agrícola. Piracicaba: POTAFOS, 1987. p.203-230.

ROLIM, F.A. Estacionalidade de produção de forrageiras. In: PEIXOTO, A.M.; MOURA, J.C. (ed.). Pastagens: fundamentos da exploração racional. Anais. Piracicaba: FEALQ, 1994. p.533-565.

ROSO, C.; RESTLE, J.; SOARES, A.B. et al. Produção e qualidade de forragem da mistura de gramíneas anuais de estação fria sob pastejo contínuo. Revista Brasileira de Zootecnia, v.28, n.3, p.459-467, 1999.

SAS INSTITUTE. SAS/STAT: user's guide, versão 6,4. Cary, 1990. 846p.

SEIXAS, P.F.; MOREIRA, A.L.; REIS, R.A. et al. Avaliação de cinco cultivares de aveia (Avena spp.) para a produção de sementes em Jaboticabal, SP. In: REUNIÃO ANUAL DA SOCIEDADE BRASILEIRA DE ZOOTECNIA, 38., Piracicaba, 2001. Anais. Piracicaba: SBZ, 2001. p.99-100. 
SHANDS, H.L.; CISAR, G.L. Avena. In: HALEVY, A.H. CRC handbook of flowering. Boca Raton: CRC Press, 1988. p.523-535.

SILVA, D. J. Análise de alimentos: métodos químicos e biológicos. Viçosa: Imprensa Universitária, 1981. 165 p.

TILLEY, J.M.A.; TERRY, R.A. A two-stage technique for the "in vitro" digestion of forage crops. Journal of the British Grassland Society, v.18, n.2, p.104111, 1963.

VAN SOEST, P.J. Nutritional ecology of the ruminant. Corvalis: Comell University, 1982. $374 \mathrm{p}$.

VILELA, H.; GOMIDE; J.A.; COELHO SILVA, J.F. Valor nutritivo da aveia forrageira (Avena byzantina $\mathrm{L}$ ) sob as formas de verde, silagem e feno. Revista Brasileira de Zootecnia, v.7, n.1, p.145-157, 1978.

VILELA, H.; MOREIRA, H.A.; VELOSO, J.A.F. et al. Aveia (Avena Sativa L) como forrageiras de inverno: adubação e irrigação em solo de cerrado. Arquivo da Escola de Veterinária, v.22, p.103-111, 1970.

WERNER, J.C. Estudo de épocas de aplicação da adubação nitrogenada em capim colonião (Panicum maximum Jacq.). In: REUNIÃO ANUAL DA SOCIEDADE BRASILEIRA DE ZOOTECNIA, 7., Piracicaba, 1970. Anais. Piracicaba: SBZ, 1970. p.21-22.

WILKINS, R.J. The potential digestibility of cellulose in forage and faeces. Journal of Agricultural Science, v.73, n.1, p.57-64, 1969. 
ZIMMER, A.H. Efeito de níveis de nitrogênio e de resíduos pós-pastejo sobre a produção, a estrutura e a qualidade das cultivares Aruana e Vencedor de Panicum maximum. Jaboticabal, 1999. 213 p. Tese (Doutorado) - Faculdade de Ciências Agrárias e Veterinárias, Universidade Estadual Paulista "Júlio de Mesquita Filho". 